\title{
ADAPTAÇÃO DE METODOLOGIAS DE CULTURA DE TECIDOS VISANDO O MELHORAMENTO ATRAVÉS DE INDUÇÃO DE MUTAÇðES EM Citrus sinensis (L.) OSBECK CV. PERA
}

\author{
MARI ANGELA CRISTOFANI \\ Engenheiro Agrónomo
}

Orientador: Prof. Dr. Augusto Tulmann Neto

\begin{abstract}
Dissertação apresentada a Escola Superior de Agricultura "Luiz de Queiroz" da Universidade de Sao Paulo, para obtenção do t1tulo de Mestre em Agronomia, Area de concentração: Genetica e Melhoramento de Plantas.
\end{abstract}

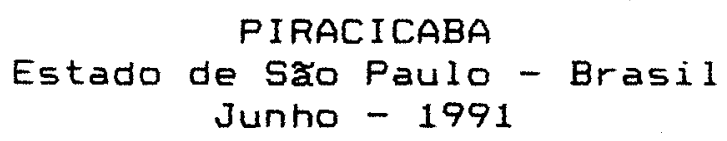


Ficha catalográfica preparada pela Seçăo de Litoros da Divisăo de Biblioteca e Documentação - PCAP/USP

Cristofani, Mariangela

C933a Adaptaçäo de metodologias de cultura de tecidos visando o melhoramento através de induçăo de muta çōes em Citrus sinensis (L.) osbeck cv. Pera. Pi racicaba, 1991.

185p. ilus.

Diss. (Mestre) - ESALQ

Bibliografia.

1. Laranja pera - Cultura de tecido - Metodolo gia 2. Laranja pera - Melhoramento 3. Laranja peraMutaçăo induzida I. Escola Superior de Agricultura Luiz de Queiroz, Piracicaba

CDD 634.31 


\section{ADAPTAÇ.̃̃ DE METOdOLOGIAS DE CULTURA DE TECIDOS VISANDO O MELHORAMENTO ATRAVES DE INDUÇ.̃̃ DE MUTAÇOES EM Citrus sinensis (L.) OSBECK cV. PERA}

Mariângela Cristofani

Aprovada em: 27/06/1991

Comissão Julgadora:
Prof. Dr. Augusto Tulmann Neto
CENA/USP
Prof. Dr. Akitiko Ando
ESALQ/USP
Dra. Beatriz M. Januzzi Mendes
CENA/USP
An guets bulnanmalo
Prof. Dr. Audusto Tulmann Neto
Orientador


Aos meus pais VICENTE E AVANILDA

e aos meus irmãos

NIVALDO, SILVIA E

RODRIGO,

ofereço. 


\section{AGRADECIMENTOS}

Ao Dr. Augusto Tulmann Neto, pela orientaça, amizade e interesse por minha carreira cientifica.

A Dra. Beatriz M.J. Mendes pela amizade e inestimável ajuda na elaboraça deste trabalho.

Ao Prof. Dr. Akihiko Ando pela amizade e ensinamentos transmitidos.

A Professora Beatriz Appezzato e a Magali Aparecida Rodrigues Machado pela amizade e orientaçăo nos estudos dos cortes histologicos realizados no presente trabalho.

Á Benedita Ines F.P. Rodrigues e Wlamir de Aguiar Godoy pela amizade auxllio nos trabal hos de laboratório.

Aos companheiros do curso de Mestrado, Benedita Aparecida da Silva e António Flumintian Junior e as companheiras de "República", Edna Tenório Nunes, Elaine Mendonça Bernades e Marilene Iamauti pela amizade e valiosas sugestaes a este trabalho.

Aos funcionários e estagiarios da Seção de Radiogenetica, Paulo Cassieri, Jose Benedito Alves, Cristina Falco, Edson Tobias Domingues, Rodrigo Latado e Telma Watanabe pela amizade e valiosa ajuda.

¿ FAPESP e CAPES, pela concessão da bolsa de estudos. 
Aos Departamentos de Genetica, Botanica e Bioquimica da Escola Superior de Agricultura "Luiz de Queiroz" ESALQ/USP.

A Seça de Radiogenetica do Centro de Energia Nuclear na Agricultura - CENA/USP.

A todos que de forma direta ou indireta colaboraram para a realizaçăo deste trabalho, agradeco. 
SUMARIO

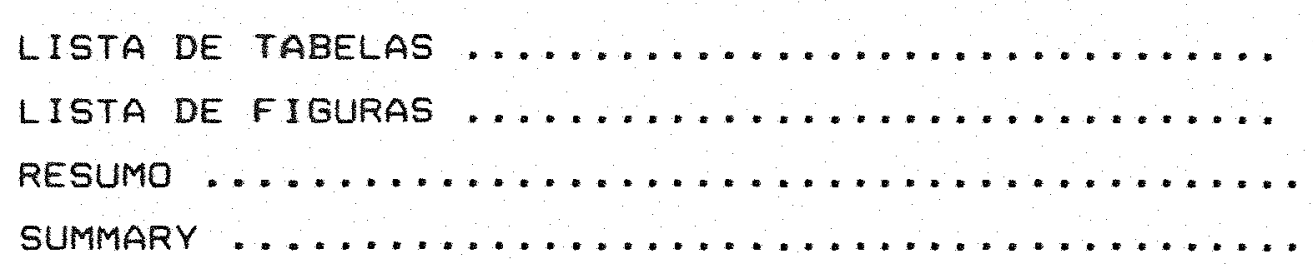

Página

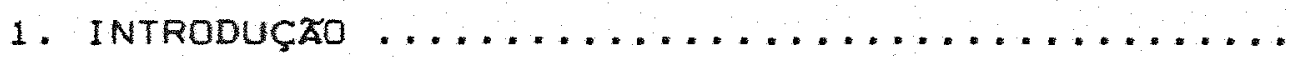

2. REVISARO DE LITERATURA ................. O. OS

2.1. Embriogenese somatica .............. os

2.2.1. Embriogenese somatica direta ...... 06

2.2.2. Embriogênese somatica indireta ....

2.2.2.1. obtençáo de calos embrio-

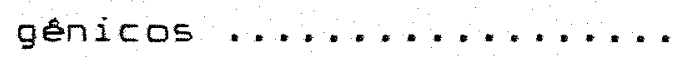

2.2 .2 .2 . Obtenção de embrižes somaticos em calos nucelares.

2.2.3. Isolamento de protoplastos ......

2.2.4. Cultivo de protoplastos ........ 26

2.2.5. Fusão de protoplastos .......... 30 2.2 .5 .1 . Obtenção de híbridos soma-

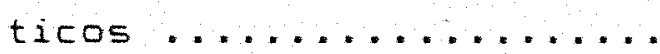

2.2 .5 .2 . obtenção de cloridos....

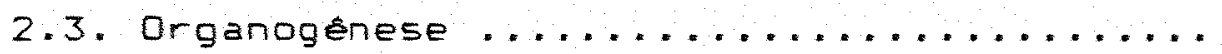

2.4. Indução de mutaçzes ............... 36

2.4 .1 . Indução de mutaçőes in vivo ...... 38

2.4.2. Indução de mutaçós in vitro ..... 41

3. MAteriaIs E metdDdos .................. 47

3.1. Procedimentos gerais ............... 47

3.2. Procedimentos especificos ............ 48 
Pagina

3.2.1. Efeito de diferentes concentraços de CIN e IAA na formacro de calos e embriódes em tecido nucelar (Expe-

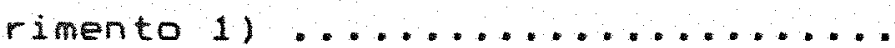

3.2.2. Efeito de diferentes meios de cultura na formaça de calos e embrioides en tecido nucelar (Experimento 2$) \ldots \ldots \ldots \ldots \ldots . . . \ldots . \ldots$

3.2.3. Indução de embriogenese somática em calos nucelares (Experimento 3 ) ...

3.2.4. Efeito de diferentes concentraçbes de CIN e IAA no desenvolvimento de plantas a partir de embribides (Ex-

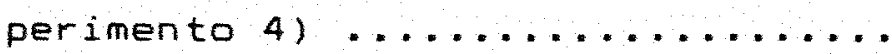

3.2.5. Efeito de diferentes meios de cultura na proliferaçăo de calo e embribides em calos obtidos em meio MT basico sem suplementação com reguladores de crescimento (Experimento 5$) \ldots \ldots \ldots \ldots \ldots \ldots \ldots . \ldots \ldots$

3.2.6. Verificação do fenómeno da habituacăo en calos nucelares (Experimen-

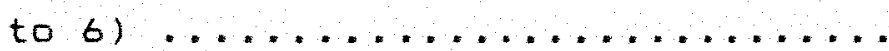

3.2.7. Efeito de diferentes concentraçoes de BAP E NAA na induça de brotaços adventicias (Experimento 7) ..

3.2 .8 . Efeito de diferentes concentraçoes de BAP na multiplicaça de brotaços adventicias (Experimento 8)...

3.2.9. Efeito de diferentes reguladores de crescimento no enraizamento das brotaçós adventicias (Experimento

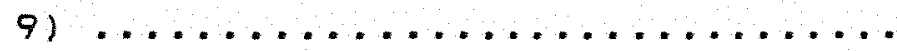


3.2.10. Cortes histologicos (Experimento

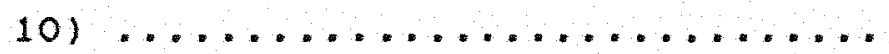

3.2 .11 . Obtença de protoplastos (Experi-

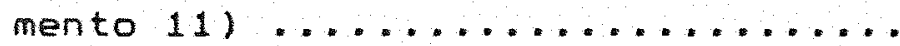

3.2 .11 .1 . Isolamento de protoplas-

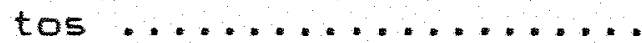

3.2 .11 .2 . Purificacao dos proto-

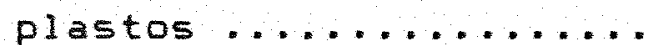

3.2 .11 .3 . Verificaça do rendimento de protoplastos durante - processo de isolamento.

3.2.12. Verificaçăo da viabilidade dos protoplastos (Experimento 12 ) .......

3.2 .13 . Cultivo dos protoplastos (Experimento 13$) \ldots \ldots \ldots \ldots \ldots \ldots \ldots$

3.2.14. Radiossensitividade dos diferentes

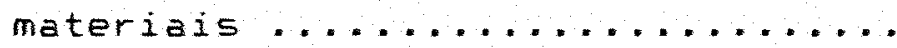

3.2.14.1. Radiossensitividade dos tecidos nucelares (Experimento $141 \ldots \ldots \ldots \ldots$

3.2.14.2. Radiossensitividade dos calos nucelares (Experimento 15$) \ldots \ldots \ldots \ldots$

3.2.14.3. Radiossensitividade em protoplastos (Experimento 16) $\ldots \ldots \ldots \ldots \ldots \ldots \ldots \ldots \ldots \ldots \ldots$

3.2.14.4. Radiossensitividade em cotiledones de embribes nucelares (Experimento 17) 
Página

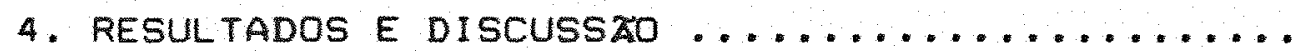

4.1. Induço de calos e embribes somaticos a

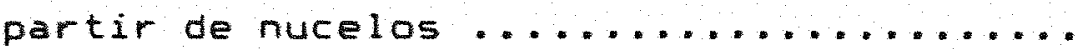

4.1.1. Efeitos de diferentes concentraçes de CIN e IAA (Experimento 1) ......

4.1.2. Efeito de reguladores de crescimento CIN, IAA e BAP (Experimento 2).

4.2. Induça de embriogenese somatica a partir de calos nucelares (Experimento 3 ) .......

4.3. Desenvolvimento de plantas a partir de embribes somáticos em meios de cultura com diferentes concentraç̧es de CIN e IAA (Ex-

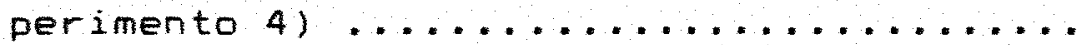

4.4. Efeito de diferentes meios de cultura no desenvolvimento dos calos nucelares e indução da embriogenese nestes calos (Expe-

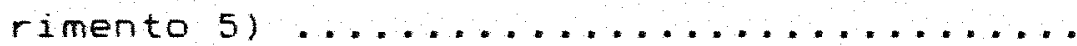

4.5. Verificaçăo da ocorrencia da habituação em calos embriogenicos (Experimento 6) ......

4.6. Indução de brotaçós adventicias (Experi-

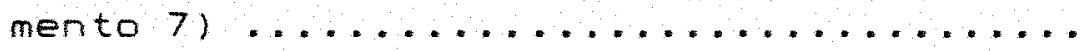

4.7. Multiplicação de brotaçóes adventicias

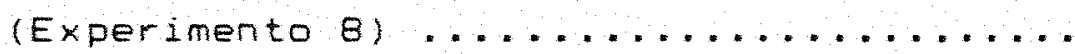

4.8. Indução de enraizamento em brotaçóes ad-

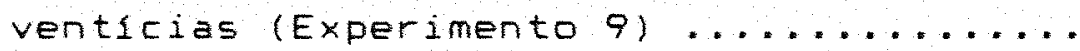

4.9. Analises histologicas (Experimento 10 ) ...

4.10. obtençao de protoplastos (Experimento 11 ).

4.11. Viabilidade dos protoplastos (Experimento

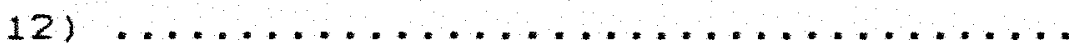

4.12. Cultivo dos protoplastos (Experimento 13 ).

4.13. Radiossensitividade dos diferentes mate-

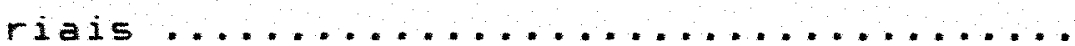


Página

4.13.1. Radiossensitividade do tecido nucelar (Experimento 14) ..........

4.13.2. Radiossensitividade en calos nucelares (Experimento 15 ) ............

4.13.3. Radiossensitividade em protoplastos (Experimento 16 ) ...........

4.13.4. Radiossensitividade em cotiledones de embribes nucelares (Experimento

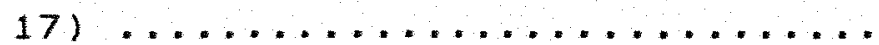

4.14. Consideraçases gerais e perspectivas futu-

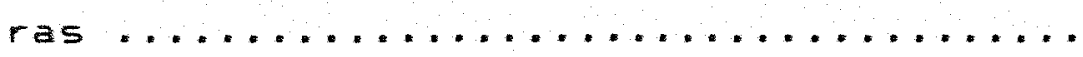

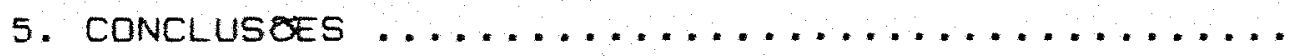




\section{LISTA DE TABELAS}

TABELA N*

Página

01 Meios de maceraçăo e purificação llavagem) de protoplastos de acordo com

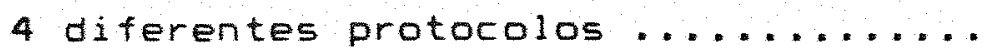

02 Meios de cultura e densidade de plaqueamento utilizados no cultivo de protoplastos isolados a partir de calos embriogenicos do cv. Pera ........

o3 Efeito das diferentes concentraçzes de CIN e IAA adicionadas ao meio MT, na formação de calos e embriódes no tecido nucelar, 8 semanas após a inoculaça

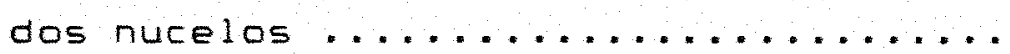

o4 Efeito dos reguladores de crescimento CIN, IAA E BAP, adicionados ao meio de cultura MT, na porcentagem de formaçăo de calos. Avaliaçós após 8 e 12 semanas de cultivo de nucelos ........

05 Efeito dos reguladores de crescimento CIN, IAA E BAP sobre o número médio de embribides obtidos por nucelo. AvaliaçZ̃es após 8 e 12 semanas de cultivo de

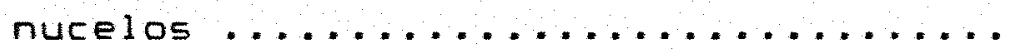


TABELA N.

06 Efeito de diferentes carboidratos sobre a embriogenese em calos nucelares obtidos em meio MT suplementado com BAP (10 mg/1). Avaliação 40 dias após cul-

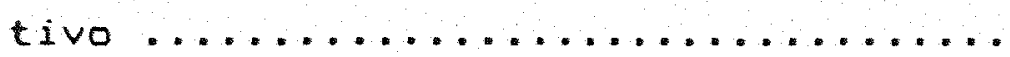

o7 Observaçes sobre o desenvolvimento de embribides en meios de cultura com diferentes concentraçBes de CIN e IAA. Avaliaça 8 semanas após o infcio do

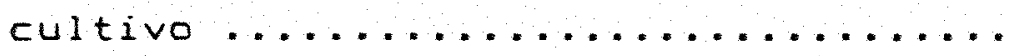

08 Peso medio dos calos e numero medio de embribes por calo cultivado em meio básico MT com diferentes suplementaços. Avaliação 40 dias apos o infcio

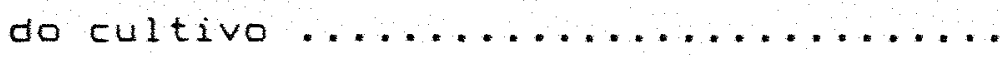

09 Crescimento de calos nucelares em meios de cultura com e sem adição de requladores de crescimento ao meio básico MT. Avaliação realizada 45 dias após

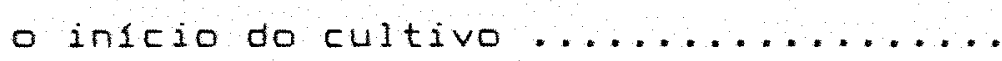

10 Efeito de diferentes concentraçbes de BAP e NAA na formação de brotaçóes adventicias na cultura de cotiledones de

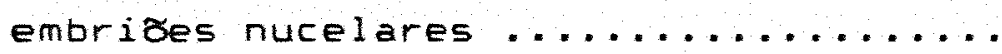


11 Efeito da concentracăo de BAP na multiplicaça de brotaçes adventicias. Avaliaça realizada 8 semanas após 0 inl-

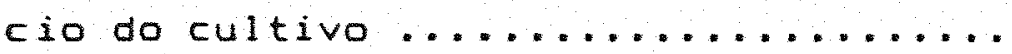

12. Porcentagem media de enraizamento, de brotaçoses em meio MT suplementado com vários requladores de crescimento. Ava1 iação 4 semanas após o infeio do cul-

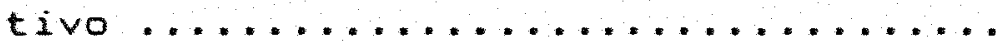

13 Rendimento médio de protoplastos isolados em diferentes tratamentos e periodos de digestão enzimatica ..........

14 Viabilidade dos protoplastos em diferentes diluiços de diacetato de fluoresceina em meio de lavagem ...........

15 Efeito da radiaça gama na formaça de embribides em nucelos. Avaliaçzes realizadas 6 e 8 semanas apos o trata-

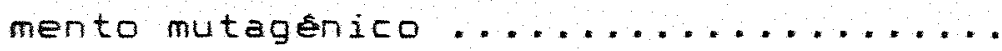

16 Desenvolvimento de embrioldes individualizados oriundos de nucelos submetidos a diferentes doses de radiação gama. Avaliação realizada 60 dias apos a inoculaça dos embribides no estádio

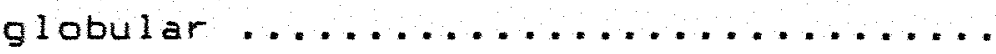


17 Efeitos de diferentes doses de radiaça gama no crescimento de calos e regeneraça de embribides a partir destes. Avaliação 40 dias após o intcio do cul-

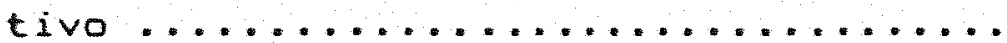

18 Desenvolvimento de embrioides individualizados oriundos de calos submetidos a diferentes doses de radiação. Avaliação realizada 30 dias apos a inoculaçăo dos embribides no estádio glo-

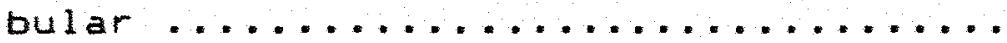

19 Germinaçăo de embribides desenvolvidos, oriundos de calos submetidos a diferentes doses de radiaçăo gama. Avaliaçăo realizada 30 dias após a inoculaçăo dos embriódes no estadio cotiledonar.

20 Viabilidade dos protoplastos submetidos a diferentes doses de radiação gama...

21 Efeito de diferentes doses de radiação gama na formação de brotaços adventicias em cotiledones de embrióes nucelares. Avaliação 90 dias apos o tratamen-

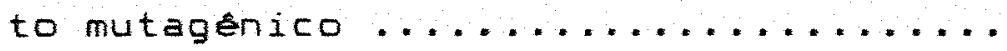




\section{LISTA DE FIGURAS}

Representação grafica do efeito de diferentes concentraçBes de CIN $e$ IAA, adicionadas ao meio MT, na formacão de calos e embrioides no

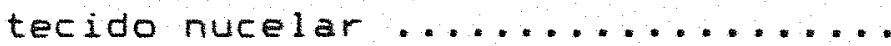

Proliferaça de calo em nucelo, em meio de cultura suplementado com $10 \mathrm{mg} / \mathrm{l}$ de BAP. (a) nucelo, (b) calo nucelar $(\times 10) \ldots \ldots \ldots \ldots \ldots \ldots$

Proliferação de calos embriogênicos em meio suplementado com $10 \mathrm{mg} / 1$ de

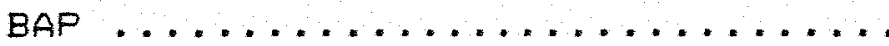

Proliferação de embribides (b) em nucelos (a) $(\times 10), \ldots \ldots \ldots \ldots \ldots$

Proliferaçăo de embribides (b) em calos nucelares $(a)(\times 10) \ldots \ldots \ldots$

Embribides normais e maduros (a) e embrioides cotiledonares normais e imaturos (b) obtidos em calos nucelares (c) cultivados em meio suplementado com $50 \mathrm{~g} / 1$ de lactose e 500 mg/l de EM, 40 dias após o cultivo

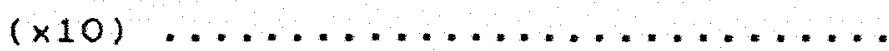


Calo embriogénico (a) apresentando embribides cotiledonares (b) e embribides no estadio globular (c) após 60 dias de cultivo em meio com $50 \mathrm{~g} / 1$ de lactose e $500 \mathrm{mg} / 1$ de EM

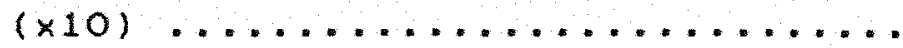

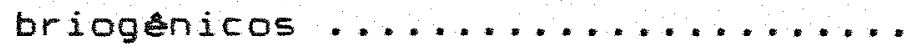

Embribides de Citrus sinensis cV. Pera em processo de maturaçao. Os diferentes estzoios de desenvolvimento podem ser observados em calos nucelares inoculados em meio suplementado com lactose e EM (a) embribide globular; (b) embribide com cotiledones em formação, (c) e (d) embribides com dois cotiledones proeminentes $(\times 10) \ldots \ldots \ldots \ldots$

Plántula regenerada via embriogenese somatica a partir de calos nucelares, apresentando raiz e parte

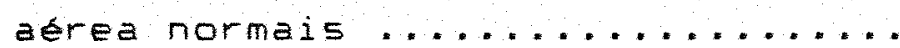

Plantula anormal com raiz e apresentando cotiledones fundidos, semelhantes a uma corneta ......... 
Plantula em roseta, apresentando raiz e formaço de cotiledones fas-

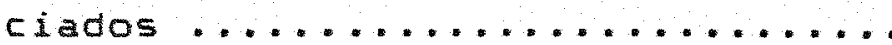

Plantula anormal enraizada apresentando un único cotiledone (a) $e$ a presenca de um meristema apical ru-

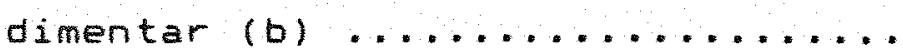

Plantulas apresentando desenvolvimento da parte aerea anormal (gemas apicais múltiplas) e raiz .......

Embriao nucelar cotiledonar (a). Cotiledones utilizados na induçăo de gemas adventicias (b) $(\times 10) \ldots$

Desenvolvimento de brotaçós adventicias em cotiledones de embribes nucelares $(\times 10) \ldots \ldots \ldots \ldots \ldots \ldots$ cias em meio suplementado com $3 \mathrm{mg} /$ 1 de $\operatorname{BAP}(\times 8) \ldots \ldots \ldots \ldots \ldots$ rentes meios de cultura 4 semanas apos o infleio do cultivo .......... 
Corte transversal da folna cotiledonar, antes da inoculaçao no meio de cultura, revelando que a epiderme constitulda por celulas compactas com núcleo grande; o mesofi10 e homogeneo e se caracteriza por apresentar celulas arranjadas de maneira justaposta, os feixes vasculares são colaterais (a) ........

Corte transversal do explante, mantido por 4 semanas em meio de cultura $(M T+3 \mathrm{mg} / 1$ de $\mathrm{BAP}+2,5 \mathrm{mg} /$ 1 de NAA). Dbserva-se acúmulo de amido em algumas células subepidermicais (a) $\ldots \ldots \ldots \ldots \ldots \ldots . . . . . .$.

Corte transversal do explante, mantido por 4 semanas em meio de cultura (MT + $3 \mathrm{mg} / 1$ de BAP + 2,5 $\mathrm{mg} /$ 1 de NAA). Dbserva-se que, em algumas areas, a epiderme e as camadas subepidermicas, eram substituldas por um meristema semelhante a um cambio de cicatrização (a) ..... a ocorrencia de meristemódes la $e$ b) $\ldots \ldots \ldots \ldots \ldots \ldots \ldots \ldots \ldots \ldots \ldots \ldots \ldots \ldots \ldots \ldots \ldots$ 
Formaçes observadas ao longo da superficie do explante (a), após 60

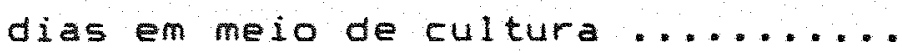

24

A análise dos cortes longitudinais do explante apos bo dias de cultivo revela a formaça de gemas vegetativas caracterizadas por apresentarem meristema apical protegido por primordios foliares (a), glan-

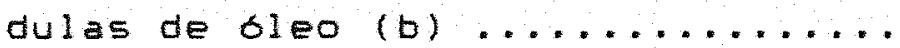

Representação grafica do efeito de diferentes tratamentos enzimaticos no rendimento do processo de isolamento de protoplastos ............

Protoplastos inoculados em meio de cultura contendo $0,45 \mathrm{M}$ de manitol e $0,15 \mathrm{M}$ de sacarose e densidade de plaqueamento de $10^{5}$ protoplastos/ml apos 15 dias de cultivo ..........

Protoplastos inoculados em meio de cultura contendo $0,25 \mathrm{M}$ de manitol e $0,15 \mathrm{M}$ de sacarose e densidade de $10^{5}$ protoplastos/ml, apos 15 dias

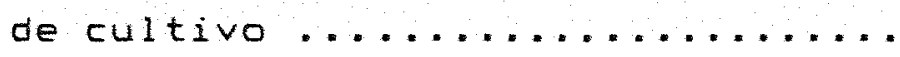


FIGURA N.

28
Representaça grafica da porcentagem de viabilidade de protoplastos em diferentes doses de radiaça gama, en relaçăo a testemunha ......
Página

152 
No decorrer do presente trabalho foram usadas abreviaturas, cujo significado e dado a seguir:

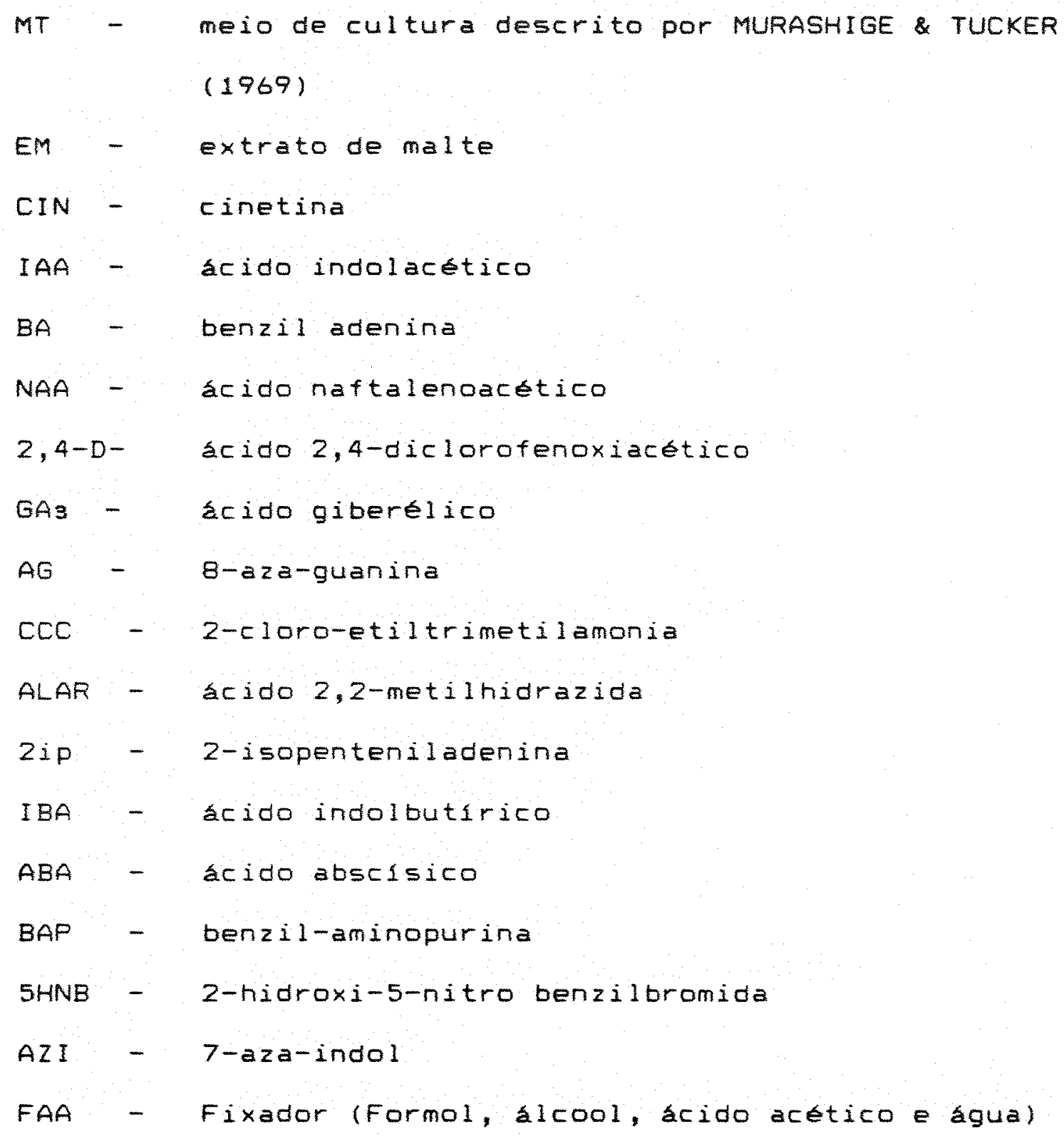




\section{ADAPTACZO DE METODOLOGIAS DE CULTURA DE TECIDOS VISANDO O MELHORAMENTO ATRAVES DE INDUCZO DE MUTACOES EMCitrus sinensis (L.) OSBECK CV. PERA}

Autora: Mariangela Cristofani Orientador: Prof. Dr. Augusto Tulmann Neto

\section{RESUMO}

- melhoramento de citros atraves de metodos convencionais tem serias limitaçbes devido a existencia dos embribes nucelares nas sementes das especies poliembrionicas, ao alto grau de heterozigose e ao longo ciclo reprodutivo, entre outros fatores.

A cultura de tecidos surgiu como uma tecnica auxiliar no melhoramento das especies cftricas visando transpor as dificuldades encontradas na aplicação dos metodos convencionais. Esta tecnica tambem tem sido empregada em trabalhos com indução de mutaçoes, visando a obtençăo de mutantes solidos, quando se utilizam agentes mutagenicos para aumentar a frequencia das mutaçoes.

o presente trabalho teve como objetivo adaptar diferentes metodologias de cultura de tecidos no cv. Pera (Citrus simensis Osbeck.), visando futuros trabal hos com indução de mutaçôs. 
Nucelos foram extraidos de sementes de frutos imaturos, 12 semanas após a antese. Embrires somaticos foram produzidos diretamente a partir destes explantes en meio MT, com diferentes concentraças de IAA e CIN. 0 meio suplementado com $1,0 \mathrm{mg} / 1$ de CIN favoreceu a formaça de embribides, principalmente atraves da formacá de embrioides a partir dos ja existentes. Calos embriogenicos foram produzidos diretamente a partir dos nucelos em meio MT suplementado com BAP $(10 \mathrm{mg} / 1)$.

Um grande número de embrioides foi obtido a partir dos calos, sendo que o meio MT suplementado com 50 g/l de lactose e $500 \mathrm{mg} / 1$ de extrato de malte foi o mais eficiente. Os embrióides produzidos a partir dos nucelos ou a partir de calos nucelares foram capazes de se desenvolver e regenerar plantas, em meio MT contendo $50 \mathrm{~g} / 1$ de sacarose e $500 \mathrm{mg} / 1$ de extrato de malte.

Protoplastos foram isolados a partir dos calos embriogenicos e sua viabilidade foi verificada pelo teste com diacetato de fluoresceina. O rendimento no isolamento foi de $1,03 \times 10^{\circ}$ protoplastos por grama de calo e a viabilidade de $84 \%$ foi verificada 1090 apos o processo de purificação dos mesmos.

Brotaçoes adventicias foram induzidas a partir dos cotiledones extraidos de embribes nucelares. As brotaçzes foram obtidas em meio MT contendo diferentes concentraçăes de NAA e BAP e suas combinaçós. Entretanto, o 
meio contendo $0,5 \mathrm{mg} / 1$ de $B A P$ e $1,0 \mathrm{mg} / 1$ de NAA foi 0 que apresentou naior numero de brotaçes por explante responsivo.

Ensaios de doses de radiacao gama for am conduzidos nos diferentes materiais: nucelos, calos nucelares, cotiledones de embribes nucelares e protoplastos, visando ia determinaça de doses recomendaveis para futuros trabalhos utilizando estes explantes na induça de mutaçชes. 


\section{ADAPTATION OF TISSUE CULTURE METHODOLOGIES AIMING} AT MUTATION BREEDING IN Citrus sinENSIS (L.) OSBECK. CV. PERA

Author: Mariangela Cristofani Adviser: Prof. Dr. Augusto Tulmann Neto

\section{SUMMARY}

Citrus improvement via conventional methods has encountered serious limitations due to the existence of nucellar embryos in the seeds of polyembryonic species, as well as to the high degree of heterozygosity and the long reproductive cycle, among other factors.

Tissue culture has emerged as an auxiliary technique for improving citrus species in order to surpass the difficulties found in applying the conventional methods. This technique has also been used in studies involving mutation induction to obtain solid mutants when mutagenic agents are used to increase mutations frequency.

The objective of the present work was to adapt different tissue culture methodologies in cv. Pera (Citrus sinensis Osbeck) to future mutation breeding of Citrus species.

Nucelli were extracted from seeds of immature 
fruit, 12 weeks after anthesis. Somatic embryos were produced directly from these explants in the MT medium with different concentrations of IAA and CIN. The medium supplemented with $1 ., 0 \mathrm{mg} / 1$ of CIN favored the formation of embryos, mainly via budding process. Embryogenic calluses were produced directly from the nucelli in the MT medium supplemented with BAP $(10 \mathrm{mg} / 1)$.

A high number of embryos was obtained from the calluses, where the MT medium supplemented with $50 \mathrm{~g} / 1$ of lactose and $500 \mathrm{mg} / 1$ of malt extract proved to be the most efficient. The embryos produced from nucelli or from nucellar calluses were able to develop and to regenerate plants in the MT medium containing $50 \mathrm{~g} / \mathrm{l}$ sucrose and $500 \mathrm{mg} / 1 \mathrm{malt}$ extract.

Protoplasts were isolated from the embryogenic calluses and their viability was verified by the test with fluorescein diacetate. The yield provided in the isolation was $1.03 \times 10^{\circ}$ protoplasts per 1 gram of callus and the viability of $84 \%$ was verified soon after the protoplasts purification process.

Adventitious buds were induced from the cotyledons extracted from nucellar embryos. Buds were obtained in the MT medium containing different concentrations of NAA and BAP and their combinations, however the medium containing $0.5 \mathrm{mg} / 1 \mathrm{BAP}$ and $1.0 \mathrm{mg} / 1 \mathrm{NAA}$ provided the highest number of buds per responsive explant. 
Gamma irradiation was conducted to the different materials: nucelli, nucellar calluses, cotyledons of nucellar embryos and protoplasts, with the aim of determining the dosages to be recommended in future studies utilizing these explants in mutation induction. 


\section{INTRODUÇÃO}

A citricultura brasileira detém a maior produça de laranja e exportaçăo de suco cftrico concentrado do mundo (FAO, 1990). Em 1990, o suco de laranja concentrado alcançou o segundo jugar como o principal produto exportado pelo Brasil (EXPORTAÇOES agroindustriais, 1991).

- Estado de São Paulo é o principal produtor de laranja do pass e e responsavel por, aproximadamente, 85\% da safra nacional (LARANJA, 1988). o cultivar Pera é o mais importante da citricultura paulista e também um dos cultivares mais preferidos pela indústria do suco (TEOFILO SOBRINHO, 1991 ).

A muda selecionada representa o principal fator de sucesso na instalaça de um pomar comercial de citros, devendo para isto, estar isenta de pragas e doenças (GREVE, 1991). Neste sentido, clones nucelares tem contribuldo para a produça de porta-enxertos e borbulhas isentos de vitoses (SALIBE, 1969).

A citricultura brasileira e considerada extremamente vulneravel, devido ao limitado número de culti- 
vares de laranja tangerina, e a uso abusivo do limao cravo como porta-enxerto (GIACOMETTI, 1980).

SEgundo BARRET \& RHODES (1976), o sistema de monocultura perene empregado nos pomares comerciais, compostos por um pequeno numero de genotipos estreitamente relacionados, faz necessario ampliar a base genetica dos cultivares de citros a fim de contornar o problema da vulnerabilidade genetica do germoplasma.

Entretanto, os trabalhos de genetica e melhoramento pouco tém contribuido para a criaçăo de novos cultivares. Os problemas associados com o melhoramento genetico de Citrus săo um reflexo do comportamento genetico e reprodutivo deste genero. Fatores tais como, longo ciclo reprodutivo, apomixia, alto grau de heterozigosidade, dificuldade de recontiecimento e sobrevivencia do hibrido originado do cruzamento entre especies elou cultivares poliembrionicos e a complexidade da determinaçáo das caracteristicas geneticas tém impedido a transferencia de genes dentro e entre os Citrus e os generos relacionados (Barret ${ }^{1}$, citado por GROSSER \& GMITTER, 1990 ).

1 BARRET, H.C. Intergeneric hybridization of citrus and other genera in citrus cultivar improvement. Proc. Int1. Soc. Citricult., 2 : $586-9,1977$. 
A maioria dos cultivares de importancia mundial foi obtida a partir de mutaçbes somaticas espontaneas (SOOST \& CAMERON, 1975). Isto demonstra o grande potencial de resposta destas especies aos tratamentos com agentes mutagenicos.

o tratamento mutagenico de tecidos multicelulares, tais como gemas e sementes, tem conduzido a formaça de plantas com quimerismo. Metodos de selecão recorrente de gemas tên sido utilizados para resolver este problema. Tais metodos entretanto, apesar de serem efetivos, sao onerosos e trabalhosos (BUTTON \& KOCHBA, 1977).

A cultura de tecidos e células, incluindo a cultura de nucelos, calos embriogenicos, gemas adventicias e protoplastos, apresenta-se entao, como uma tecnica capaz de auxiliar o melhoramento genetico das especies de citros, principalmente quando se associa a tecnica de induça de mutaçes, isto porque, dentre outras vantagens, a probabilidade de se obter mutantes solidos (plantas sem quimerismo) pode ser maior neste caso.

Levando-se em consideraçăo as dificuldades no emprego de metodos convencionais no melhoramento das especies citricas e o potencial das tecnicas de cultura de tecidos no melhoramento destas especies, objetivou-se com este trabalho, (1) estudar uma metodologia para otimizar a produça de calos embriogenicos a partir do tecido nucelar, (2) adaptar a metodologia de cultivo de proto- 
plastos isolados partir dos calos nucelares embriogenicos, (3) estabelecer um protocolo de induça e regeneraça de gemas adventicias e (4) estudar a radiossensitividade dos calos embriogenicos, nucelos, protoplastos e gemas adventicias a radiaçăo gama, visando futuros trabalhos com inducão de mutaçaes en citrus sinensis cv. Pera. 


\section{REVISÃO DE LITERATURA}

\subsection{Eubriogenese somatica}

A embriogenese somática pode ser definida como o processo de desenvolvimento de embrizes, a partir de celulas somaticas. A produça de embribes somaticos a partir da cultura de células, tecidos e orgaos pode ocorrer direta ou indiretamente. A embriogenese somática direta envolve a formaçăo de um embrião somatico, também denominado embribide (WILLIAMS \& MAHESWARAN, 1986), de origem unicelular ou de un grupo de celulas a partir do explante, sem passar por uma fase intermediaria de calo.

A embriogenese somatica indireta consiste na proliferação de calo a partir de um explante e subsequente formação de pró-embrioides a partir destes calos.

Estes dois padrós de desenvolvimento de embrizes somaticos foram observados em cultura de ovulos inteiros elou nucelos em citros. A embriogénese somatica direta de ocorrencia notável en cultivares de citros poliembriónicos, onde celulas pre-existentes no tecido nucelar dao origem aos embribes nucelares (in vivo ou in vitro). Em 
varios casos, estes embrioides poden ser produzidos a partir da cultura de embrizes imaturos (TISSERAT, 1985). 0 cultivo de protoplastos provenientes de calos embriogenicos tambem tem resultado na diferenciaço de embribes somaticos por via direta e indireta (KOBAYASHI et alii, 1985).

Em ambos os padrzes de formaça, o emorizo somatico seque a mesma sequencia de desenvolvimento do embrizo zigotico, ou seja, a passagem pelos estadios globular, cordiforme e torpedo, seguido pela formação da planta (SCHULTHEIS et alii, 1990 ).

\section{2.1. Embriogenese somática direta}

Vários trabalhos foram realizados com o cultivo in vitro de nucelos e ovulos isolados das especies c1tricas, visando a obtença de embribes somaticos para a produçă de porta-enxertos vigorosos e isentos de viroses (NAVARRO \& JUAREZ, 1977) e tambem, em trabalhos que visavam a indução de mutaçôs (KOCHBA et alì, 1972; KOCHBA \& SPIEGEL-ROY, 1977 ; STARRANTINO \& RUSSO, 1976-1977).

Embribes zigóticos e nucelares de muitos cultivares de citros foram cultivados com sucesso (OHTA \& FURUSATO, 1957; RANGASWAMY, 1958; 1959, 1961; RANGAN Et aliI, 1969). A induçăo de embriogenese somatica foi realizada em muitas especies e cultivares de citros. Embrizes somaticos foram produzidos de cultivares poliembrionicos, com ou sem 
sementes, atraves da cultura de tecido nucelar excisado de semente em desenvolvimento (TISSERAT \& MURASHIGE, 1977), ovulos abortivos (BITTERS et alii, 1970 ) e ovulos nao fertilizados (BUTTON \& BORNMAN, 1971; KOCHBA et alii, 1972), assim como, atraves da cultura de ovulos inteiros fertili$z$ ados ou nå (BUTTON \& BORNMAN, 1971; KOCHBA et alii, 1972 e MITRA \& CHATURVEDI, 1972). A técnica de cultura de ovulos e nucelos in vitro foi utilizada também, e com sucesso, na induçăo de embriogenese somática em uma serie de cultivares monoembrionicos (RANGAN et alii, 1968, 1969; BITTERS et aIii, 1970; NAVARRO \& JUAREZ, 1977; BUTTON \& KOCHBA, 1977$).$

Estudos revelaram a existencia de celulas com citoplasma denso e núcleo grande no tecido nucelar, na extremidade micropilar do saco embrionario, nos cultivares poliembriónicos. No cultivar Trovita (C. sinensis), estas celulas inciaram a divisao ao mesmo tempo ou logo apos a divisão do zigoto, cerca de 50 dias apos a polinização. Estas celulas foram denominadas de celulas primordiais do embriao nucelar e nå foram observadas nos cultivares monoembriónicos (KOBAYASHI et alii, 1981).

Este tipo de estudo importante em trabaIhos visando à indução de mutaçôs, pois o tratamento mutagenico dos explantes, antes da formaça dos embrioides, propicia um metodo ideal na produçăo de mutantes solidos. 
Neste sentido, KOCHBA et ali i (1972), atraves de estudos histologicos em tres cultivares, Shamouti a Valencia (Citrus sinensis) e Marsh Seedless (C. paradisi), verificaram que ovulos e nucelos extraldos de frutos com 1-8 semanas de idade nåo apresentavam o desenvolvimento de embribes nucelares.

A epoca de extraça e o tipo de explante (ovulos inteiros ou nucelos) tén variado bastante, de acordo com a espécie utilizada nos diferentes trabalhos, e parecem ter influencia na resposta quanto à porcentagem e ao número medio de embrizes por explante responsivo.

BUTTON \& KOCHBA (1977) observaram que nos cultivares monoembrionicos, somente nucelos extraldos de sementes em desenvolvimento produziram embribes somaticos. Esta afirmação está de acordo com o que NAVARRO \& JUAREZ (1977) observaram trabal hando com cultivares monoembrionicos de Clementine (C. reticulada Blanco). Estas variedades săo auto-incompativeis e foram polinizadas com pólen de Comuna (C. sinensis), com a finalidade de induzir a formação de sementes. Os autores obtiveram resultados satisfatorios, utilizando frutos com 13 a 15 semanas apos a polinização.

Entretanto, NAVARRO \& JUAREZ (1977), trabaIhando com cultivares poliembrionicos do grupo Navel, utilizaram ovulos excisados de ovarios de flores, antes da antese e ovulos de frutos em desenvolvimento, obtidos uma a 
dez semanas apos a antese. En todas as fontes eles observaram uma taxa semelhante de embriogenese, indicando que a idade do fruto, na epoca da excisao do ovulo, aparentemente, nå determina o número de ovulos que văo produzir embriódes. Esta observaça nao esta de acordo com os resultados obtidos para ocv. Shamouti por KOCHBA et alii (1972), no qual as mais altas porcentagens de ovulos, mostrando formaçao de embrioides, foram verificadas em ovulos extraldos de frutos quatro semanas após a antese. GOLDMAN (1988) encontrou meIhores respostas em ovulos, do cultivar Pera ( $C$. sinensis Osbeck), excisados 10 semanas apos a antese.

\section{KOCHBA et alii (1972) verificaram que os} nucelos extraldos dos cultivares valencia e Marsh resultaram em maior porcentagem de formaçăo de embribides do que a cultura de ovulos. Este fato tambem foi verificado por GOLDMAN (1988), em cultura de ovulos e nucelos do cv. Pera, onde nucelos extraidos de frutos com 10-12 semanas produziram as maiores porcentagens $(27-69,47 \%)$ de embriogenese, em todos os tratamentos, em comparação com o cultivo de ovulos, com a mesma idade, apos 12 semanas de cultivo.

Os resultados de embriogenese, encontrados para o cultivar Pera, variando de 0 a $25 \%$, nos ovulos, por GOLDMAN (1988), estáo de acordo com os resultados obtidos por KOCHBA et alii (1972), MOORE (1985) E GMITTER \& MOORE (1986). Por outro lado, resultados entre 50 a $70 \%$ de emoriogenese, em ovulos, foram verificados por STARRANTINO \& 
RUS50 (1980) 80 a $100 \%$ para os cultivares do grupo Navel (NAVARRO JUAREZ, 1977 ).

Os ovulos em certos cultivares apresentam um desenvolvimento mais lento in vitro que os nucelos. NAVARRO \& JUAREZ ( 1977 ) obtiveram enbribides de ovulos cultivados por ate 15 semanas sem qualquer sinal previo de diferenciaçå, no cv. Navel. GOLDMAN (1988) observou que os nucelos em cultivo formaram embribides mais rapidamente e em maior porcentagem que os ovulos, no cv. Pera.

Outros fatores tais como genótipo da planta doadora do explante e composiçao do meio de cultura tem sido observados influenciando na porcentagem de explantes responsivas.

o meio de cultura idealizado por MURASHIGE \& SKOOG (1962) e sua modificaça realizada por MURASHIGE \& TUCKER (1969) contribulram muito para um maior sucesso na cultura e morfogenese de ovulos e outros orgaos de citros.

- extrato de malte fol relatado como sendo benefico a cultura de ovulos e nucelos (KOCHBA et alil, 1972). Em vários outros trabalios, esta substancia foi adicionada ao meio de cultura, na concentração de 500 mg/1, para estimular a indugão da embriogenese (NAVARRO \& JUARE 2,1977 ; STARRANTINO \& RUSSO, 1980). Um estudo realizado por MOORE (1985), com o cv. Marsh (Citrus paradisi) demonstrou que o extrato de malte favoreceu a formaça de embrioides neste cultivar e que o aumento da concentraçao 
desta substancia para $1000 \mathrm{mg} / 1$ aumentou em sete vezes a porcentagen de óvulos responsivos en relaça a concentraça de $500 \mathrm{mg} / 1$.

A caselna hidrolizada e a aqua de coco também tem sido relatadas estimulando a embriogenese em tecidos nucelares de citros (SABHARWAL, 1963; BUTTON \& BORNMAN, 1971; MITRA \& CHATURVEDI, 1972; PASQUAL, 1985).

Outros componentes importantes săo os requladores de crescimento, que săo compostos da maior significancia na cultura de tecidos de plantas. Segundo Esan ${ }^{2}$, citado por pasqual et alii (1988), a adicá das auxinas IAA, NAA e 2,4-D ao meio de cultura, suprimiu significativamente ou completamente a embriogenese nucelar. Este fato tambem foi observado por MOORE (1985) com a utilizaça de IAA, GAs e ABA no cV. Marsh (C. parasisi) e por PASQUAL et alii (1988) com 2,4-D no cv. Valencia.

Por outro lado, TISSERAT \& MURASHIGE relataram que O IAA, em baixas concentraç̧es, suprimiu levemente a embriogenese no cV. Ponkan ( $C$. reticulata Blanco) em culturas nucelares.

Um fato interessante, observado por MoORE (1985), foi que a adiça de diferentes substancias ao meio de

\footnotetext{
2 ESAN, E.B., 1973. A detailed study of adventive embryogenesis in the rutaceae. University of California, Riverside (dissertaça). $233 p$.
} 
cultura, influenciou a embriogenese de forma semelhante aquela relatada em trabalhos sobre induca de embriogenese somática a partir de calos nucelares.

Assim, da mesma forma que ocorreu nas culturas de calos nucelares (KOCHBA \& SPIEGEL-ROY, 1977b; KOCHBA et alii, 1978), a presença de auxina IAA, no meio de cultura ra suprimiu a embriogenese em ovulos do cv. Marsh. Assim como, a porcentagem maxima de ovulos responsivos foi verificada con a adicão de $0,01 \mathrm{mg} / 1$ de daminozida, um inibidor da sintese de GAs (MOORE, 1985).

Em un trabalho posterior, GMITTER \& MOORE (1986) estudaram o comportamento de varios genótipos de Citrus em diferentes meios, contendo substancias de crescimento. Os ovulos dos cultivares de laranja doce, cultivados em meio de cultura com 2,4-D e daminozida ou extrato de malte, na presença de luz, foram os mais efetivos na formação de embriódes.

MITRA \& CHATURVEDI (1972), examinando tres genotipos, encontraram uma relação direta entre o grau de poliembrionia em um genótipo e seu potencial para formaço de embribides in vitro. Qutros pesquisadores relataram diferenças na formaça de embriódes entre cultivares de $C_{1-}$ trus poliembriónicos e monoembriónicos, mas as diferenças nas respostas, devido ao grau de poliembrionia, não foram examinadas (BUTTON \& BORNMAN, 1971; BUTTON \& KOCHBA, 1977). 
MOORE (1985) observou, em seu trabalho, que os cultivares de $C$. sinensis e C. paradisi tem um al to grau de poliembrionia, em relaço aos outros clones examinados. Os cultivares destas duas especies tiveram também a maior porcentagen de ovulos responsivos e a maior media de embribides por óvulos responsivos que os outros clones. Entretanto, houve varias exceços para esta caracteristica, dentro dos cultivares poliembrionicos. Outros fatores, alem do grau de poliembrionia, parecem influenciar o número de embribes produzidos a partir de ovulos nao desenvolvidos de frutos maduros (MOORE, 1985 ).

\section{2. 2. Embriogénese somatica indireta}

A embriogenese somática pode ocorrer indiretamente a partir de ovulos e nucelos, atraves do processo de formação de calos e posterior formação de embrioides a partir destes. RANGASWAMY (1958) observou a formaça de calos em nucelos de ovulos fertilizados em citrus microcarpa.

Posteriormente, outros autores relataram o aparecimento esporadico de pequenos calos em cultura de ovulos e nucelos, alem de embrioides diferenciados diretamente destes explantes (RANGASWAMY, 1961; SABHARWAL, 1963: BUTTON \& BORNMAN, 1971; MITRA \& CHATURVEDI, 1972, KOCHBA et a Ii i, $1972)$ 
KOCHBA et alii (1972) cultivaram ovulos e nucelos do ev. Shamouti, Valencia e Marsh in vitro e observaram que enquanto os cultivares Valencia e Marsh mostraram altas porcentagens de cultura com formaça de embrioides originarios dos ovulos e nucelos, um pequeno número de embribides formou-se diretamente destes explantes no cultivar Shamouti. Em compensaça, este cultivar formou calos que nao foram observados nos outros dois cultivares. A produça, diferenciaça dos calos, obtenção de embribides e plantas a partir destes seria, desta forma, um metodo alternativo para aplicaçăo em trabalhos, visando a induça de mutaça en cultivares ou especies que produzem poucos embribides a partir do nucelo.

A obtenção de calos nucelares foi estendida para outros genótipos de Citrus com a finalidade de se obter protoplastos totipotentes a partir destes materiais (VARDI et alii, 1982; KOBAYASHI et alii, 1984; GROSSER \& CHANDLER, 1987; VARDI \& GALUN, 1988).

\subsubsection{1. obtençăo de calos embriogenicos}

Os explantes utilizados nos trabalhos com indução de calos tém sido nucelos e ovulos. Entretanto, tem sido observada a formaça destes calos na regia do hipocotilo dos embrioides obtidos a partir destes explantes (HIDAKA \& KAJIURA, 1988; GOLDMAN, 1988). 
GOLDMAN (1988), trabalhando com nucelos e bvulos do cv. Pera (C. sinensis Osbeck), verificou a formaça de calos embriogénicos na regiao do hipocótilo de embrioides produzidos a partir de nucelos, cinco a sete meses apos a inoculação do explante nucelar en meio de cultura. Apos este periodo de cultura, os nucelos apresentaram altas porcentagens de calos embriogenicos $(34,52$ a $71,12 \%)$ quando comparados com os ovulos, apos o mesmo tempo de cultivo. Resultados semel hantes foram obtidos para o cultivo de nucelos de cultivares monoembrionicos, porem, os calos surgiram diretamente da região micropilar dos nucelos, após 3-6 semanas de cultivo (JUAREZ et alii, 1976).

Ainda de acordo com o trabaltho de GOLDMAN (1988), os ovulos produziram, de uma forma geral, baixas porcentagens de calos embriogenicos $(0$ a $17,36 \%)$. Estes resultados estão de acordo com aqueles obtidos por VARDI et alii (1982) que observaram uma frequiencia geralmente baixa na produçăo de calos ovulares (cerca de $24 \%$ para os cultivares de tangerina e $2 \%$ para os cultivares de "grapefruit").

$$
\text { SPIEGEL-ROY \& VARDI (1984) afirmaram que, }
$$

para cada cultivar elou especie, o estagio otimo para a retirada dos explantes, destinados ao desenvolvimento de calos, deve ser determinado separadamente.

Para o cultivar Shamouti, os melhores resultados na obtença de calos foram obtidos atraves da cultu- 
ra de ovulos extraldos de frutos, 2 a 5 semanas apos a antese (KOCHBA et alii, 1972). Para o cultivar Pera, os melhores resultados foram conseguidos com ovulos extraldos de frutos com 12 semanas apos a antese (GOLDMAN, 1988). Entretanto, o que se observa nos trabalhos com sistemas de protoplastos onde calos foram obtidos de várias especies de Citrus, que ovulos extraldos de frutos com 2-6 semanas após a antese foram utilizados invariavelmente para qualquer uma das especies estudadas (VARDI et alii, 1982; ZHANAO et alii, 1989).

SEgundo SPIEGEL-ROY \& VARDI (1984), as células nucelares de Citrus são pre-determinadas como células embriogenicas e a adição de reguladores de crescimento vegetais não e necessária para induzir a embriogenese somatica. Entretanto, segundo SAAD (1975), a adiça de $2,4-D$ foi necessaria para indução de calos embriogenicos em cultivares de Citrus limon.

A adiçăo de requladores de crescimento aos meios de cultura para induçăo de calos embriogenicos pode ser constatada en várias pesquisas. KOBAYASHI et alii (1983), trabalhando com ovulos excisados de gemas florais do cv. Trovita (Citrus sinensis), obtiveram calos em meio MT (MURASHIGE \& TUCKER, 1969) sUPlementado com $100 \mathrm{mg} / 1$ de extrato de malte e $20 \mathrm{mg} / 1$ de sulfato de adenina, onde, apos tres meses, numerosos embribides e pequenos calos foram obtidos. Entretanto, a frequencia de indução de calos não 
foi suficientemente alta. Estes calos foram,entao, propagados em meio MT suplementado com $10 \mathrm{mg} / 1$ de BAP. Posteriormente, KOBAYASHI et alii (1984) estudaram o efeito dos reguladores de crescimento NAA, BAP e suas combinaçbes na induça de calos em ovulos de ev. Bahia com a finalidade de estabelecer um meio de cultura mais eficiente. 0 meio de cultura suplementado com $10 \mathrm{mg} / 1$ de BAP foi o mais eficiente na produça de calos embriogénicos, neste cultivar. Calos nucelares foram induzidos em onze cultivares estudados coito cultivares de laranja doce, Citrus junos, Citrus deliciosa, "Nova") neste mesmo meio de cultura (KOBAYASHI et alii, $1984)$.

HIDAKA \& KAJIURA (1988) obtiveram calos embriogenicos a partir de embrizes originados de sementes imaturas de três especies de Citrus: C. Sinensis Osbeck (Washington Navel), C. yuko (Yuko) e C. reticulata Blanco (Ponkan), em meio de cultura MS suplementado com $0,16 \mathrm{M}$ de sacarose e 50 MM de cinetina. Um a tres meses apos a inoculaçă, calos friaveis foram produzidos na regiao do hipocotilo destes embribides.

A utilizaço de reguladores de crescimento na indução de calos embriogenicos também pode ser verificada no trabalho realizado por ZHANAO et alii (1989), com ovulos obtidos de frutos com $1-6$ semanas apos 0 florescimento e cultivados em meio MT suplementado com IAA $0,1 \mathrm{mg} / \mathrm{I}$ e cinetina $1,0 \mathrm{mg} / 1$. 
Entretanto, em varios outros cultivares, obteve-se a formaça de calos atraves do cultivo de ovulos e nucelos em meio de MURASHIGE \& TUCKER (1969), suplementado com $500 \mathrm{mg} / \mathrm{l}$ de extrato de malte e $50 \mathrm{~g} / 1$ de sacarose sem adiça de reguladores de crescimento (KoCHBA et alii, 1972 ; VARDI et alii, 19821 .

KOCHBA \& SPIEGEL-ROY (1973) verificaram que os ovulos e nucelos do ev. Shamouti, quando mantidos em meio $M T+500 \mathrm{mg} / 1$ de EM, desenvalviam pequenas quantidades de calos. Para induzir maior crescimento, estes calos foram subcultivados em meio MT suplementado com $1 \mathrm{mg} / \mathrm{l}$ de cinetina e $1 \mathrm{mg} / 1$ de IAA. Este meio produziu um rapido crescimento dos calos. Depois que estes calos proliferaram neste meio de cultura, foram transferidos para outros diferentes meios de cultura suplementados com AD, EM, IAA E CIN com a finalidade de se estudar o crescimento dos calos e o desenvolvimento de embriós, a partir destes,em meios suplementados com diferentes substancias e concentraçaes de reguladores de crescimento.

Um fato interessante observado por KOCHBA \& BUTTON (1974) e, posteriormente, por outros autores (SPIEGEL-ROY \& KOCHBA, 1975; HIDAKA \& KAJIURA, 1988; ZHANAO Et alii, 1989, GROSSER \& GMITTER, 1990) \& que calos subcultivados em diferentes concentraçbes de IAA e cinetina podem tornar-se habituados, em relaçao a estes reguladores de crescimento apos alguns subcultivos. 
Segundo SKIRVIN (1978), a habituaço a perda da necessidade de fornecimento exogeno de fatores de crescimento, geralmente de auxinas, ao meio de cultura, para crescimento dos calos.

A habituacao, provavelmente, representa uma mudanca na expresszo genica envolvendo o sitio da sintese dos reguladores de crescimento. O fato de MEINS (1974) ter observado que plantas provenientes de celulas totipotentes habituadas so produziram calos na presença de reguladores de crescimento, indica que a habituaça, provavelmente, năo tem origem mutacional, mas representa uma resposta epigenetica. Porem, a verdadeira explicaçăo permanece descontiecida (SKIRVIN, 1978).

\subsubsection{Obtenção de embrióes somaticos em calos nucelares}

A embriogenese em cultura de calos de Citrus de or igem nucelar estimulada por uma variedade de substancias e condiços de cultivo (KOCHBA \& BUTTON, 1974; SPIEGEL-ROY \& KOCHBA, 1973 ; KOCHBA \& SPIEGEL-ROY, 1977b; KOCHBA et $a 1 i i, 1978)$.

KOCHBA et alii (1978) assumiram que as condiçbes que reduzem o nivel endogeno de auxinas, em calos habituados (independentes de auxinas e citocininas), levam ao aumento na embriogenese, e isto esta de acordo com o que 
foiverificado por TISSERAT \& MURASHIGE (1977), en seUs estudos com cultivares de Citrus mono e poliembrionicos.

Calos embriogenicos, do cultivar shamouti, expostos a radiação gama, mostraram um estimulo na formaçăo de embribes somaticos com doses de 12 a $20 \mathrm{kR}$, sendo que o efeito máximo foi observado com a dose de $16 \mathrm{kR}$ (SPIEGEL-ROY \& KOCHBA, 1973).

KOCHBA \& BUTTON (1974) verificaram que o "envelhecimento", isto e, o periodo de tempo em que os calos permanecem em um mesmo meio de cultura, entre um subcultivo e outro, estimulou a embriogenese em calos do cv. Shamouti. KOCHBA \& SPIEGEL-ROY (1977C) também observaram este efeito, sendo que, a maior produção de embriąes somáticos ocorreu quando os calos foram mantidos por dez a quinze semanas no mesmo meio de cultura antes do subcultivo. A omissão de sacarose no meio de cultura, por um periodo de subcultivo estimulou a embriogenese de modo semelhante ao "envelhecimento" (KOCHBA \& BUTTON, 1974 ).

Nos meios de cultura onde foram utilizados reguladores de crescimento para acelerar o crescimento dos calos, verificou-se que os baixos nIveis de cinetina e IAA, separadamente, induziram uma maior diferenciação de embribides, que os niveis mais altos ou as combinaçoes destes reguladores de crescimento (KOCHBA \& SPIEGEL-ROY, 1973). 
A embriogenese inibida por aplicaçes exogenas de IAA, NAA, ou citocininas tais como cinetina, BAP e 2ip (KOCHBA \& SPIEGEL-ROY, 1977b; KOBAYASHI et alii, 1984).

Por outro lado, a embriogenese somatica estimulada por inibidores da sintese de auxinas tais como sHNB e AZI (KOCHBA \& SPIEGEL-ROY, 1977b) e por inibidores da sintese de GAs (KOCHBA et alii, 1978), tais como CCC e ALAR. A aza-guanina ( $A G$ ), que exerce um efeito antagonico sobre as citocininas, estimulou a embriogenese em calos do ev. Shamouti (KOCHBA \& SPIEGEL-ROY, 19776).

- efeito de vários carboidratos na embriogenese e desenvolvimento de embribides foi estudado em detaIhe nos cultivares shamouti ( $C$. sinensis), Villafranca ( $C$. limon), King (C. nobilis), laranja azeda ( $C$. aurantium) e Navel (C. Sinensis) (KOCHBA et alii, 1982). A galactose e a lactose estimularam, consideravelmente, a embriogenese em todos os cultivares estudados. A glicose e a frutose foram os carboidratos menos efetivos no estimulo a embriogenese.

A adiça de galactose e lactose, na concentraçăo de $50 \mathrm{~g} / 1$, quando comparada com outras adiços ao meio MT, tais como, extrato de malte, sulfato de adenina, água de coco, extrato de levedura, acido casaminico, BAP e NAA, produziu um notavel aumento no número de embribides por cultura de calo (KOBAYASHI et alii, 1984). 
BEN-HAYYIN \& NEUMANN (1983) estudaram o efeito do glicerol no crescimento e embriogenese, nos calos obtidos da cultura de óvulos de várias especies e/ou cultivares de Citrus. oglicerol estimulou a embriogenese em calos que foram capazes de utiliza-lo como fonte de carbono para o crescimento. o glicerol e utilizado, eficientemente, por algumas especies de citrus. Segundo os autores, o conhecimento do comportamento dos calos de Citrus em glicerol pode servir como um fator de seleça para os experimentos de fuszo de protoplastos.

A galactose tem se mostrado uma boa fonte de carbono para o crescimento de todos os calos de Citrus estudados e calos derivados de protoplastos (KOCHBA et alii, 1982; VARDI et a 1 i i, 1982).

2.2.3. Isolamento de protoplastos

As pesquisas sobre protoplastos abriram amplas possibilidades para o melhoramento genetico das especies cltricas. Varios trabal hos, utilizando protoplastos, foram desenvalvidos com indução de mutaçßes (VARDI et alii, 1975; ZHANAO et alii, 1989), seleça in vitro (VARDI et alii, 1986), fusao (KOBAYASHI et aIiI, 1988; GROSSER \& GMITTER, 1990) e transformaçăo (VARDI et ali1, 1990).

BUTTON \& BOTHA (1975) E VARDI et alii (1975), simultaneamente, desenvolveram um sistema de isolamento de 
protoplastos a partir de calos embriogenicos originados de ovulos do cv. Shamouti (Citrus sinensis). VARDI et alii (1975) conseguiram a regeneraça de plantas a partir dos protoplastos e estabeleceram a sequencia completa de planta $\rightarrow$ protoplastos $\rightarrow$ colonia de celulas $\rightarrow$ calos embriogenicos $\rightarrow$ embrióides, en trabalho visando a induça de mutaçós em protoplastos.

Posteriormente, a regeneraça de plantas via embriogenese somatica, a partir de protoplastos, foi estendida para vários outros genótipos de Citrus, como se pode verificar en excelentes revisbes realizadas por VARDI \& GALUN (1988), GOLDMAN (1988) E GROSSER \& GMITTER (1990), sendo que o maior sucesso foi obtido com cultivares de laranja doce (Citrus sinensis).

Em geral, as culturas de calos embriogenicos e culturas em suspensao dos mesmos propiciaram excelentes fontes de protoplastos totipotentes. Tais culturas podem ser mantidas em meio de cultivo sem reguladores de crescimento (VARDI, 1977; VARDI et aIii, 1982; GROSSER \& GMITTER, 1990), ou em meio contendo al tos niveis de BAP (KOBAYASHI et alii, 1988).

GROSSER \& CHANDLER (1987) desenvolveram um protocolo eficiente para isolamento de protoplastos de folhas e calos de diferentes cultivares e especies de Citrus.

A obtenção de calos embriogenicos pode ser 
dificil de se conseguir en muitos genótipos. Em diferentes trabalhos realizados, protoplastos de folhas eram fundidos com aqueles provenientes de calos embriogenicos, dando origem aos hibridos somaticos. Recentemente, TUSA et alii (1990) relataram a regeneraça de plantas a partir de protoplastos de folhas do limao Femminello'. Mas ate entao, a obtença de plantas a partir de protoplastos so havia sido descrita para aqueles provenientes de calos embriogenicos.

Alguns fatores podem influenciar no processo de isolamento dos protoplastos. Nă se dispze de nenhum dado numerico a respeito do impacto da idade dos calos, ou melhor, o tempo decorrido entre um subcultivo e outro, no rendimento (número de protoplastos/ml), no processo de isolamento dos protoplastos. Entretanto, diversos autores recomendam que os calos nåo sejam mantidos por mais de tres semanas no mesmo meio de cultura, antes do processo de isolamento dos protoplastos (VARDI et alii, 1982; KOBAYASHI et alii, 1983, KOBAYASHI et alii, 1988; HIDAKA \& KAJIURA, $1988)$ e que os subcultivos sejam realizados a cada quatro semanas. Nas culturas em suspensă, recomenda-se que o subcultivo seja realizado a cada 15 dias (GROSSER \& GMITTER, 1990).

outros fatores, tais como, pressá osmotica do meio de maceração, a fonte $e$ a combinação das enzimas para a digestão da parede celular, afetam o rendimento 
dos protoplastos a posterior capacidade de divisao dos mesmos em meio de cultura.

Foram realizados vários protocolos, onde as concentraçes e as fontes das enzimas variam para cada cultivar elou especie (VARDI \& GALUN, 1988). Segundo VARDI et alii (1982), a macerozyme produziu melhores resultados nos diversos cultivares analisados do que a pectinase.

o rendimento, no isolamento, tem variado entre $10^{6}$ a $4 \times 10^{\circ}$ protoplastos/grama de calo e o tempo de digestao enzimática, entre 4 a 16 horas, dependendo da concentraça enzimatica, do material tratado (folhas, calos embriogenicos e năo embriogenicos) e dos genótipos, de acordo com os diversos protocolos ja estabelecidos para citrus e gêneros relacionados.

A concentração osmotica do meio de maceração tem sido mantida por volta de $0,7 \mathrm{M}$, sendo que os açúcares mais utilizados tém sido o manitol e a sacarose, em combinaçăo ou apenas o manitol (VARDI \& GALUN, 1988 ; GROSSER \& GMITTER, 1990$)$ :

o meio MT, com a metade da concentração dos macronutrientes $e$ sem os micronutrientes e vitaminas, tem se mostrado bastante adequado para o isolamento de protoplastos.

E importante lembrar que um bom rendimento no isolamento dos protoplastos não pode ser considerado como um fator isolado, pois muitos dos protoplastos podem nă ser 
viáveis. Por esta razá, aconselhavel o estudo da viabilidade dos protoplastos apos o isolamento. Neste sentido, muitos trabalhos tem sido realizados, principalmente, com a utilizaça de corantes como por exemplo, o diacetado de fluorescelna (BURGER \& HACKETT, 1982). Existem muitos corantes que podem ser utilizados para avaliar a viabilidade dos protoplastos (ERIKSON, 1985). O azul de metileno tambem é un corante que tem sido amplamente utilizado em protoplastos vegetais (Hooley ${ }^{3}$, citado por GOLDMAN, 1988).

\subsection{Cultivo de protoplastos}

Vários fatores podem influenciar no sucesso do cultivo dos protoplastos, entre eles, os considerados mais importantes são a densidade de plaqueamento e a osmolaridade do meio de cultura.

A densidade dos protoplastos no meio de cultura tem grande influencia no processo de divisão e diferenciação dos mesmos (NAGATA \& TAKEBE, 1971 ; VARDI et alii, 1975; KOBAYASHI et alii, 1985).

VARDI et alii (1975) verificaram que nos protoplastos do cV. Shamouti, os melhores resultados, quanto ao

3 HOOLEY, R. Protoplastos isolated from aleurone layers of wild oat (Avena fatua L.) exibit the classic response to gibberelic acid. Planta, 154: 29-40, 1982. 
numero e tamanho das colonias de celulas formadas em meio de cultura foram conseguidos com a densioade de $10^{5}$ e $8 \times 10^{4}$ protoplastos/ml. A mais alta densidade de plaqueamento utilizada $\left(4 \times 10^{5}\right.$ protoplastos/mi) resultou na formaço de pequenas colonias de celulas que logo cessaram o ereseimento.

KOBAYASHI et alii (1985) realizaram um estudo para estabelecer as condiçós adequadas para a embriogenese a partir de protoplastos do cv. Troviata e notaram que em uma densidade de plaqueamento de $4 \times 10^{4}$ protoplastos/ml com $0,15 M$ de manitol, $75 \%$ dos protoplastos dividiram-se e desenvolveram-se em embrioides. Em contraste, quando os protoplastos foram cultivados a uma densidade de $10^{5}$ protoplastos/ml, estes dividiram-se formaram calos.

De uma forma geral, a densidade de plaqueamento utilizada nos diferentes trabalhos tem sido de $10^{5}$ protoplastos/m1 (VARDI \& GALUN, 1988; GROSSER \& GMITTER, $1990)$.

Com a finalidade de se obter a divisão dos protoplastos, nos casos em que o plaqueamento for realizado com baixa densidade $\left(10^{3}-10^{2}\right.$ protoplastos/mi), estes podem ser plaqueados sobre uma camada "al imentadora", formada por protoplastos que tiveram sua divisao interrompida pelo uso da radiação $x$ ou gama (VARDI \& RAVEH, 1976). plaqueamento a uma baixa densidade de protoplastos sobre uma camada "alimentadora", um procedimento conveniente 
quando o numero de protoplastos viáveis desconhecido fpor exemplo, apos un tratamento mutagenicol e, especialmente, apos a fusa de protoplastos quando numero de protoplastos produzidos pela fusão variável e năo previsivel (VARDI et alis, 1989$)$.

Os protoplastos, sendo celulas isoladas, desprovidas de parede celular, representam um sistema bastante eficiente na absorça de elementos minerais do meio. A otimizaça do meio de cultura um fator primordial para a aplicação desta tecnologia. Em geral, a exigencia nutricional para a cultura de protoplastos a mesma para celulas isoladas (CARNEIRO \& CONROI, 1990 ).

Em citros, tem sido utilizado, na maioria dos trabalhos, o meio de MURASHIGE e TUCKER (1969), sem reguladores de crescimento e com os estabilizadores osmóticos descritos anteriormente. HIDAKA KAJIURA (1988) utilizaram o meio de MURASHIGE \& SKOOG (1962) e GROSSER \& GMITTER (1990) idealizaram um meio de cultura, com composiçăo mais complexa, utilizado principalmente para o cultivo de genótipos mais recalcitrantes.

Os protoplastos de citros têm uma fase "lag" relativamente extensa. As primeiras divisós são geralmente observadas $10-14$ dias apos o plaqueamento. o tempo necessario para a formaça de calos e afetado por vários fatores, entre eles estão a fonte de protoplastos e a densidade de plaqueamento (VARDI \& GALUN, 1988). Segundo GROSSER \& 
GMITTEF (1990), a eficiencia de plaqueamento, definida como a porcentagem de protoplastos que se dividem para produzir colónias, geralmente varia de $0-35 \%$.

A formaça de colonias de celulas entao seguida pelo desenvolvimento de calos e finalmente pela produça de embribides a partir destes calos. Os embrioides se tornam aparentes 6 a 7 semanas apos o plaqueamento dos protoplastos (VARDI et alii, 1982; KOBAYASHI et alii, 1988). O número de embribides formados de cada colónia baixo e, na maioria dos casos, nem todos mostram a capacidade de formar plantas normais. O glicerol tem sido utilizado para estimular a embriogénese nestes calos (GROSSER \& GMITTER, 1990$).$

Segundo VARDI \& GALUN (1988), quando os calos derivados de protoplastos atingem o diametro de $1-2$ $\mathrm{mm}$, eles são individualizados e transferidos para meio MT contendo $4 \%$ de sacarose para melhorar o crescimento dos mesmos. Calos que atingem o diametro de $7 \mathrm{~mm}$ săo transferidos para o meio MT com $2 \%$ de glicerol para inducão de embribides. Os embribides sao individualizados e cultivados em meio MT contendo $4 \%$ de sacarose e $1.500 \mathrm{mg} / 1$ de EM. EmbriZes com folhas cotiledonares expandidas sao transferidos para tubos contendo meio MT com $2 \%$ de sacarose e 0,02$0,05 \mathrm{mg} / 1$ de NAA. A adição de NAA promove a formação da raiz e olongamento do eixo caulinar. Posteriormente, as plantulas sao aclimatizadas e transferidas para o solo. 


\subsubsection{Fusão de protoplastos}

\subsubsection{Obtenczo de hibridos somáticos \\ o genero Citrus foi o primeiro genero arbo-} reo no qual um processo eficiente foi estabelecido para regenerar plantas a partir de protoplastos (VARDI et alis, 1975, 1982; KOBAYASHI et alii, 1983; GROSSER \& CHANDLER, 1987; KOBAYASHI et alii, 1987 e VARDI \& GALUN, 1988). VARDI et alii (1986) obtiveram tambem a regeneraço de plantas a partir de protoplastos do genero Microcitrus. Estes trabaIhos foram, então, a base para trabalhos posteriores, visando, inclusive, a fusăo de protoplastos.

o primeiro exemplo de hibridação somatica bem sucedida envolvendo Citrus foi um hibrido intergenerico alotetraploide produzido pela fusão de protoplastos de calos embriogenicos do cV. Trovita (C. sinensis) com protoplastos de folnas de Poncirus trifoliata (OHGAWARA et alii, 1985).

GROSSER et alii (1988) produziram os primeiros hibridos somaticos a partir de generos sexualmente incompativeis. A fusão foi realizada entre protoplastos isolados de uma cultura de calos, em suspensão, de Citrus sinensis, com protoplastos isolados de calos originados na região do epicotilo de Severinia disticha (Blanco). A produça deste hibrido demonstrou que a fusáo de protoplastos é uma forma viavel de transpor a barreira da hibridação 
sexual que existe entre Citrus e os generos relacionados potencialmente importantes.

KOBAYASHI et alii (1988) obtiveram o primeiro hibrido interespectfico produzido pela fusao de protoplastos do ev. Washington Navel (Citrus sinensis) e cv. Hayashi (tangerina satsuma - C. unshiu). Trata-se de uma combinaça potencialmente importante para o melhoramento da copa, onde - progresso atraves do melhoramento convencional tem sido Iimitado.

Os trabalhos realizados com Mibridacáo sommatica em citros podem ser encontrados em GROSSER \& GMITTER (1990). A verificação de que os produtos da fusão eram de fato hibridos somaticos foi baseada, principalmente, na caracterizaçăo do formato das folhas, contagem do número de cromossomos e analise dos rDNAs com auxilio das endonucleases de restrição.

SEgundo GROSSER \& GMITTER (1990), a hibridaça somatica tem vantagens sobre a hibridaça sexual para o mel horamento de eitros, en termos de combinar pais com caracteristicas complementares; sem perda significante do vigor, na maioria dos casos, resultando na expressao aditiva das caracteristicas dominantes nos hibridos. A hibridaçáo somática pode propiciar uma forma de utilizar clones estéreis nos esquemas de melhoramento, ou de transpor incompatibilidades de cruzamento na criaça de formas hibridas, previamente impossiveis entre especies e generos. 
Consequentemente, novos genótipos potencialmente valiosos podem ampliar a base genetica dos citros.

Porem, há alqumas consequencias geneticas que resultam da fusăo de protoplastos na criaça de novas formas de hibridos nos citros. Primeiro, um dos pais deve ter poteneial embriogenico in vitro, e isto limita o grupo de materiais disponiveis para a hibridaça somatica. Segundo, os hibridos somáticos podem nao apresentar desenvolvimento normal de flores ou serem inferteis, especialmente, hibridos que combinam os pais geneticamente distantes. Também, o pareamento preferencial dos cromossomos pode inibir a recombinaçăo genetica nos tíbridos somaticos. Uma terceira consequencia seria da incorporação dos hibridos somaticos nos programas de melhoramento e que os ciclos subsequentes da hibridação sexual, para o avanço de geraçaes (p.ex. retrocruzamento dos hibridos com um dos pais para eliminar caracteristicas indesejáveis), serzo em nivel tetraploide. Se os tetraploides săo hibridizados com diploides pode ocorrer a formaça de triplódes inferteis. Estes triploides podem ter valor comercial por nã possuirem sementes, entretanto, sua utilidade na continuidade do processo de melhoramento genético será minima. E, finalmente, a eliminação da oportunidade de segregação e recombinaçăo, normalmente propiciada pela hibridaçăo sexual, significa que somente uma combinaçăo hibrida pode ser produzida por qualquer par de parentais e,portanto, nenhuma variaça de 
caracteres produzida sobre a qual deva ser aplicada uma pressao de seleço (GROSSER \& GMITTER, 1990).

\section{2 .5 .2 . obtença de cloridos \\ A cibridação (VARDI et alii, 1987) ou fusao} utilizando protoplastos irradiados com raios gama pode ajudar a transpor algumas das consequências da hibridaça somatica (GROSSER \& GMITTER, 1990).

o método de fusao de protoplastos denominado de doador-receptor foi utilizado em citros pela primeira vez por VARDI et alii (1987) para obter cloridos entre Citrus e Microcitrus. Este metodo consiste em interromper ou inativar a divisao nuclear do protoplasto doador atraves da irradiação com altas doses (no caso de protoplastos de Citrus, 50 a $60 \mathrm{kR})$ de raios $x$ ou $\gamma$. A divisão do protoplasto receptor é impedida por um antimetabolico (p.ex., iodoacetato) causando uma inibigão metabolica transitoria. Posteriormente promovida a fusão do protoplasto doador com - receptor.

Este tipo de fusão pode resultar em plantas clbridas de citros que tem a morfologia codificada pelos genes nucleares do protoplasto receptor, mas contem também os novos genomas mitocondriais do protoplasto doador, que pode ser verificado pela analise dos padrbes das enzimas de restrição do DNA mitocondrial (VARDI et alii, 1987).

A produça de tais cibridos de citros tendo o 
genoma nuclear de um dado cultivar e genoma extranuclear de outro emuito relevante para estudos geneticos e para o melhor amento deste genero, porque năo há informaçes sobre a herança citoplasmática en citros. Tais informaças podem ter um impacto direto sobre o melhoramento de citros, isto porque, varias caracteristicas, como por exemplo, resistencia aos patbgenos e herbicidas, assim como a macho esterilidade citoplasmática podem ser controladas pelos genomas presentes nas organelas (VARDI \& GALUN, 1988 ).

\subsection{Organogênese}

A embriogénese somática só foi conseguida até - momento a partir de ovulos e nucelos ou a partir de calos formados nestes explantes. Entretanto, a cultura de outros orgãos e tecidos em citrus tem resultado na formação de plantas via organogenese (SPIEGEL-ROY \& VARDI, 1984).

A organogenese ocorre atraves da formação de gemas adventicias que sao assim denominadas por terem origem em locais diferentes daqueles onde se formam no curso normal de desenvolvimento da planta. A sua formaça ocorre de maneira direta ou indireta. A organogenese direta refere-se ao surgimento direto de gemas a partir de tecidos que apresentam potencial morfogenetico nas plantas in vivo, mas que, em geral, năo se expressa. A organogenese indireta 
ocorre quando o processo de regeneracao de gemas e precedido pela formaça de calo. A partir de celulas nao organizadas do calo surgem gemas adventicias que crescem e se desenvolvem em novas partes aereas IGRATTAPAGLIA \& MACHADO, $1990)$

o primeiro relato sobre organogenese em cultura de tecidos em Citrus foi realizado por GRINBLAT (1972). Calos, gemas e plantas foram obtidos em cultivo de segmentos de caule de plantulas do $c V$. Calamondin ( $C$. madurensis).

Posteriormente, a organogenese foi obtida em calos de diferentes cultivares elou especies de Citrus a partir de folhas, segmentos de caule e ralzes (CHATURVEDI \& MITRA, 1974; CHATURVEDI \& MITRA, 1975; EDRISS \& BURGER, $1984)$.

A produção de plantas diretamente de segmentos nodais do caule, segmentos de epicotilo e ralzes e pontas de ralzes tambem foi relatada (BURGER \& HACKETT, 1981; MATSUMOTO \& YAMAGUSHI, 1983; MOORE, 1986; EDRISS \& BURGER, 1984; BURGER \& HACKETT, 1986; DURAN-VILLA Et alii, 1989).

Em cultura de tecidos, os principais fatores que controlam a morfogenese sao os fitorreguladores, particularmente o balanço auxina-citocinina no meio de cultura, fato estabelecido no classico trabaliho de SKOOG \& MILLER (1957). Esses autores verificaram que tal balango, con- 
venientemente manipulado, induzia em calos originados da medula de fumo, a formaçăo de ralzes, gemas caulinares ou apenas mais tecido de calo.

Nos processos de organogenese em Citrus, calos e gemas formadas direta ou indiretamente a partir dos explantes tem sido obtidos em meio de sais minerais e vitaminas de MURASHIGE \& SKOOG (1962) OU MURASHIGE \& TUCKER (1969) contendo diferentes concentracoes de NAA e BAP e suas combinaç̧es. A adiçăo de NAA, em concentracão adequada, ao meio básico de cultura tem favorecido a formaçăo de raszes nas brotaçes obtidas.

2. 4. Indução de mutações

Estudos geneticos em Citrus são complicados devido a presença de embribes nucelares nas especies poliembrionicas, ao al to grau de heterozigosidade, a incompatibilidade, a esterilidade e a longo perlodo de juvenilidade das plantas obtidas por sementes. A embrionia nucelar em Citrus e um importante obstáculo para a hibridação, mas é de grande importancia na produçăo de porta-enxertos vigorosos, uniformes e isentos de viroses (FROST \& SOOST, 1968).A auto-incompatibilidade foi demonstrada em Citrus grandis (SoOst, 1964), na tangerina Clementine, nos tangelos, em alguns cultivares de Citrus limon, em Citrus limettoides e 
Citrus sinensis (SOOST CAMERON, 1975). Fatores geneticos para esterilidade em óvulos e polen estao presentes em algumas especies de Citrus (IWAMASA, 1966).

Um al to grau de heterozigosidade esta presente na maioria das especies de citrus devido, presumivelmente, aos seguintes fatores: (1) a ocorrencia frequente de mutaçao genetica espontanea, (2) cruzamentos naturais entre especies distantes e (3) embrionia nucelar. A reproducáo por embrionia nucelar preserva a heterozigosidade que pode se originar atraves da hibridação ou mutação (SOOST \& CAMERON, 19751 .

A existencia de pouca variabilidade entre os cultivares de limbes verdadeiros e entre os cultivares de laranja pode representar, principalmente, uma origem através de mutação somatica espontanea. As tangerinas, entretanto, tem uma ampla base genetica, sugerindo uma maior diferenciação nos cultivares atraves de reprodução sexual (SOOST \& CAMERON, 1975 ).

Quando as mutaçós ocorrem, sua expressão nos tecidos somaticos e favorecida pela heterozigosidade da maioria das especies de Citrus. Tal heterozigosidade, por sua vez, implica em que as mutaçbes devem ter ocorrido frequetemente no passado.

As mutaç̧es espontaneas tem sido relatadas em varias especies de citrus. SOOST \& CAMERON (1975) listaram vários mutantes em muitas especies de citrus e mencionaram 
que a maioria dos cultivares comerciais surgiu de algum tipo de mutaçăo espontanea.

A indução de mutaçós, atraves do uso de agentes mutagenicos, aumenta a frequencia das mutaçbes e afeta o espectro da mutaça (HOWLAND \& HART, 1977).

Devido aos problemas encontrados no emprego de metodos convencionais de melhoramento genetico nas especies cltricas e ao grande potencial de resposta destas especies ao emprego da técnica de induçăo de mutaçbes, varios trabalhos foram desenvolvidos in vivo ou in vitro.

2. 4.1. Indução de mutaç̧es in vivo

- primeiro relato sobre o uso de raios $x$ para induzir mutaçós em plantulas de citrus aconteceu em 1935 (Haskins Moore", citado por RUSSO et alii, 1981). Os raios $x$ aplicados as sementes de 5 especies de Citrus produziram varias anormalidades nas plantulas, tais como, fasciaçă, fol has bi ou trifoliadas e um grande número de plantulas albinas.

Os trabalios de melhoramento genetico com Citrus utilizando a tecnica de induçăo de mutaç̧es tiveram grande impulso na decada de 70 , concentrando-se na obtenção

\footnotetext{
HASKINS, C.P. \& MOORE, C.N. Growth modifications in citrus seedlings grown from $x$-rayed seed. Plant Physiology, 10: 179-185, 1935 .
} 
de amadurecimento precoce e lta qualidade dos frutos obtidos de mutantes espontaneos, subsequentemente na indução de mutantes sem sementes com a utilizaça de radiaçáo gama e outros mutagenicos fisicos e quimicos (ZHANAO et alii, 1989 ).

HENSZ (1971) obteve um novo cultivar de "grapefruit" denominado de Star Ruby de coloração vermel ha intensa atraves da irradiaçáo de sementes com nêutrons termicos. Este cultivar recebeu reconhecimento em todos os palses onde se cultiva "grapefruit". Entretanto, alguns produtores obtiveram baixa produça de frutos e voltaram a utilizar o cultivar original a partir do qual o star Ruby foi obtido. Outra progenie obtida neste mesmo programa de melhoramento atraves da indução de mutaçăes e mantida por vários anos produzindo árvores vigorosas, frutiferas e frutos de coloração vermel ha intensa como os do cultivar star Ruby foi introduzida recementemente (HENSZ, 1990).

Em geral, a maioria dos projetos de melhoramento, atraves da induça de mutaçzes, foi iniciada recentemente e anda não se obteve mutantes comerciais. BROERTJES \& VAN HARTEN (1988) Iistaram dois cultivares mutantes com produçá comercial que sao, o ja comentado star Ruby, e o ev. Hongju 418, um cultivar de laranja doce, sem sementes e atamente produtivo eriado na China em 1983.

Estes mesmos autores fizeram uma revisao sobre este assunto, onde citam trabalhos realizados na URSS 
e China, principalmente, com o uso de mutagenicos +1sicos e quimicos en sementes e borbulhas para obter plantas com frutos sem sementes, plantas de porte compacto, frutos com melhores caracteristicas com amadurecimento precoce e tambem, melhora na atividade fotossintetica da planta.

HEARN (1985) obteve varios clones promissores juvenis, sem sementes do cV. Foster em "grapefruit", através da irradiaça de borbulhas com as doses de $30-50$ GY de raios gama.

Da mesma forma, SPIEGEL-ROY et alii (1985) obtiveram uma linhagem mutante de limăo Eureka sem sementes a partir de borbulhas irradiadas com 6 kR de raios gama de uma fonte de ${ }^{\infty} \mathrm{Co}$.

RUSSO et alii (1981), tambem fazendo uso da mutagenese aplicada ao melhoramento de Citrus, irradiaram borbulhas com raios $x$ e obtiveram frutos com número reduzido de sementes no cv. Monreal Clementine (Citrus reticulata).

No Brasil, TULMANN NETO et alii (1990) estzo utilizando a tecnica de indução de mutaçбes com o objetivo de obter resistencia ao cancro cltrico (xanthomonas campestris pv. citril e outras caracteristicas na laranja doce (Citrus sinensis Osb.). A irradiação resul tou em uma grande variabilidade nas caracteristicas agronómicas. A seleçăo para resistencia ao cancro esta em andamento.

A obtenção de resistencia a Xanthomonas citri em um cultivar de grapefruit foi relatada por ZUBRZYCKI \& 
ZUBRZYCKI (1982). Estes mesmos autores estão trabal hando na obtença de resistencia ao virus da tristeza utilizando a induça de mutaços.

Un outro enfoque dado a utilizaça da radiaçăo visando diminuir o número de embrizes nucelares nas espécies poliembriónicas. IKEDA \& NISHIDA (1977) descobriram que a formaça de embribes nucelares poderia ser restringida atraves da irradiaça de borbulhas florais com raios gama. Desta forma, WATANABE (1985) obteve hibridos $F_{1}$ pela regulação da poliembrionia atraves da radiação gama em cultivares de Citrus unstiv.

2. 4. 2. Indução de mutações in vitro

As tecnicas de cultura de tecidos e celulas foram introduzidas visando contornar os problemas de quimerismo e seleçăo diplóntica ocorridos quando se faz irradiação de borbulhas e sementes (KOCHBA \& SPIEGEL-ROY, 1977a; ZHANAO Et alii, 1989).

outra vantagem de se utilizar a inducăo de mutaçbes invitro, no melhoramento, e que grandes populaçbes de individuos podem ser tratadas e submetidas a pressáo de seleçăo sob condiçós uniformes. Os processos in vitro podem ser utilizados inclusive para suspensós celulares, culturas de protoplastos, embriogenese somatica 
em cultura de celulas em suspensao ou calos, em gemas adventicias e en material tratado com mutagenico in vivo, do qual setores de tecidos mutantes sao utilizados in vitro para recuperar os mutantes (CONSTANTIN, 1984).

Os trabalhos realizados por KOCHBA et alii (1972) com cultura de ovulos e nucelos de tres cultivares de Citrus, tinham como objetivo estudar a diferenciaçăo de explantes nucelares e expor as culturas ao tratamento mutagenico, antes do desenvolvimento de embriódes. Isto possibilitaria a induçăo de mutaçăo nas células nucelares de onde posteriormente haveria a regeneraça de mutantes sólidos.

PASQUAL (1985) estudou a radiossentividade, sob diferentes condiçbes, em nucelos extraldos do cv. Valencia (Citrus sinensis) e encontrou o valor da LDso (dose que causa $50 \%$ de letalidadel de $1-2 \mathrm{krad}$. Forem, SPIEGELROY \& KOCHBA (1977a) observaram um aumento na formaça de embribides nas doses de 0,5 e $1,0 \mathrm{kR}$ em relaçăo a testemunta. Segundo KOCHBA \& SPIEGEL-ROY (1977a), OVulos em estadio apropriado de desenvolvimento para os trabalnos com indução de mutação estão disponiveis por um periodo de tempo limitado. A extração do nucelo e trabalhosa e os explantes nucelares sã extremamente sensiveis a radiação gama, o que torna diflcil a realização de estudos com indução de mutaçóes nestes explantes.

Um programa de melhoramento de Citrus utilizando indução de mutaçóes foi iniciado na Italia em 1974 
com a finalidade de induzir resistencia a "mal secco" no lima "Femminello siracusano" (C. Iimon L. Burm. f.). Este cultivar extremamente importante na ltalia devido a grande produtividade e boa qualidade de seus frutos. Aproximadamente 120 dias apos a polinizaça, frutos imaturos foram irradiados a uma exposiça total de $2 \mathrm{kR}$ e $4 \mathrm{kR}$. Os nucelos foram excisados das sementes destes frutos e cultivados in vitro (STARRANTINO \& RUSSO, 1976-1977).

A partir da determinaça da metodologia para obtença de calos embriogenicos de cultura de óvulos de Citrus (KOCHBA et alii, 1972; SPIEGEL-ROY \& KOCHBA, 1973), vários trabalhos foram realizados no sentido de se estudar o efeito da radiação sobre estes calos (SPIEGEL-ROY \& KOCHBA, 1973; KOCHBA \& SPIEGEL-ROY, 1977a).

Altas doses de radiaça gama $(12-20 \mathrm{kR})$, especialmente $16 \mathrm{kR}$, estimularam significativamente a formaça de embrioides e inibiram o crescimento dos calos do cv. Shamouti. Porem, este estimulo significante ocorreu a uma taxa de dose de $3,1 \mathrm{kR} / \mathrm{h}$. Aplicando-se uma taxa de $50 \mathrm{kR} / \mathrm{h}$ o estamulo ocorreu mas foi pequeno a $100 \mathrm{kR} / \mathrm{h}$ ocorreu uma reduça na formaça de embribides (SPIEGEL-ROY \& KOCHBA, $1973)$

SPIEGEL-ROY \& KOCHBA (1973) relataram que o efeito parece ser devido as mudanças ocorridas no meio de cultura, provocadas pela radiagao. Porem, este efeito nao foi observado quando experimentos foram realizados em calos 
habituados do ev. Shamouti (KOCHBA SPIEGEL-ROY, 1977(C).

KOCHBA \& SPIEGEL-ROY (1977c) verificaram que alguns fatores tais como, periodo de tempo entre um subcultivo e outro, e a inoculaçăo dos calos, após irradiaça, em meios com diferentes concentraçbes de IAA podem modificar - efejto da radiaçáo sobre os calos. Estes autores chamaram atença para o fato de que os calos em subcultivo apresentam-se en vários estádios de desenvolvimento, desde colulas isoladas, ate pro-embribides (BUTTON et alii, 1974). Portanto, estes diferentes estadios podem responder de modo diferente a irradiação. A constituiça dos explantes muda com a idade dos calos, sendo que é esperada uma composiçá menos uniforme com o aumento da idade dos calos. Verificou-se tambem que a sensitividade dos calos as doses mais altas aumentou com o prolongamento do periodo de subcultivo dos mesmos, e que diferentes niveis de reguladores de crescimento podem influenciar na embriogenese dos calos irradiados no cv. Shamouti. A inibição da embriogenese pela presença de IAA foi removida progressivamente com o aumento da dose de radiação.

Posteriormente, outros trabalhos foram realizados utilizando calos embriogenicos habituados do cv. Shamouti irradiados com doses de 8,12 e 16 kR la uma taxa de dose de $85 \mathrm{kR} / \mathrm{hl}$ e calos nåo irradiados, visando a seleça in vitro para resistencia a salinidade, herbicidas e es- 
treptomicina (KOCHBA et aii, 1982, SPIEGEL-ROY et alii, 1983; KoCHBA et alii, 1982). Mutagenicos quimicos e raios gama foram utilizados para induça de mutaçes em calos de diferentes cultivares de Citrus com a finalidade de selecioná-los para tolerancia ao NaCl (ZHANAO et alil, $1989)$.

Nas pesquisas realizadas com o cV. Shamouti, a comparaça náo revelou diferenças significantivas entre as linhas originadas de calos irradiados e não irradiados, quanto a tolerancia ao NaCle 2,4-D. Segundo KoCHBA \& SPIEGEL-ROV (1982), estas diferencas, entretanto, poderăo ser encontradas nas plantas regeneradas a partir destes calos.

MATSUMOTO \& YAMAGUSHI (1984) obtiveram um aumento na variaçăo para tolerância ao NaCl em embribes adventicios de Poncirus trifoliata obtidos na regiăo de transiçăo entre a parte aerea e a raz de plantulas obtidas in vitro e tratadas com EMS.

Em todos estes trabalhos, a estabilidade da tolerancia foi verificada atraves de varios subcultivos em meio sem o agente seletivo e posterior inoculaçăo em meio de cultura com o agente seletivo. Porem, nã há relatos sobre a verificaçăo da estabilidade da tolerancia em plantas adultas obtidas a partir dos calos e embribides selecionados nestes trabalhos.

Qutra técnica com grande potencial de apli- 
cacão em trabalhos con induçáo de mutaçbes a tecnica de isolamento e cultura de protoplastos. Segundo NEGRUTIU et ali (1984), a mutagenese em protoplastos constitui o único sistema em que o tratamento mutagenico pode ser aplicado em uma populaçăo relativamente sincronizada, de celulas isoladas e geneticamente homogeneas, onde existe grande probabilidade de obtença de mutantes năo quimericos.

VARDI et alii (1975) estudaram o efeito do mutagenico quimico EMS e dos raios $x$ na sobrevivencia de protoplastos, analisando a formaçăo de colonias de celulas após 4 semanas do tratamento mutagenico. Este mesmo tipo de trabalino foi realizado por GOLDMAN (1988), com protoplastos de cv. Pera tratados com raios gama e a sobrevivencia foi avaliada com o corante azul de metileno. ZHANAO et alii (1989) obtiveram embrizes somaticos originados de protoplastos de calos irradiados a partir de varios cultivares elou especies de citrus.

Um fato interessante encontrado no trabalio de VARDI et alii (1975) e que as doses de $4,5 \mathrm{kR}$ e $7,5 \mathrm{kR}$ estimularam a diferenciaça de embribes nos calos provenientes de protoplastos irradiados.

Os trabalhos com indução de mutaçôes em protoplastos de Citrus foram realizados pelos autores acima citados, para estudar a radiossensitividade dos mesmos, mas năo há relatos de obtenção de plantas adultas a partir dos protoplastos obtidos. 


\section{MATERIAIS E MÉTODOS}

Os experimentos foram realizados na seçăo de Radiogenetica do Centro de Energia Nuclear na Agricultura (CENA/USP). OS frutos foram coletados na Estação Experimental de Limeira, Instituto Agronomico de Campinas-IAC, em Cordeiropolis, São Paulo.

3.1. Procedimentos gerais

Os nucelos foram extraldos de frutos imaturos do ev. Pera Premunizada (Citrus sinensis Osbeck), aproximadamente, 12 semanas apos a antese.

A assepsia das sementes foi realizada em soluçăo composta de uma parte de água sanitária comerciall"QBoa" - hipoclorito de sodio $2 \%$ ) e tres partes de água destilada, durante dez minutos. Em seguida, em condiçzes assepticas, foram feitas tres lavagens com água destilada esteril. 
Após a assepsia, com auxilio de pinça bisturi, sob o estereo-microscopio, as sementes foran cortadas longitudinalmente en duas partes, extraindo-se o tecido nucelar de cada uma delas e retirando-se os embrioides que eventualmente ja estivessem en formaça nas sementes por ocasiao da extraça dos nucelos.

Os meios de cultivo constituiram-se basicamente, dos sais minerais e vitaminas do meio MT suplementado com reguladores de crescimento e substancias complexas de acordo com cada experimento. Os meios foram solidificados $\operatorname{com} 8 \mathrm{~g} / 1$ de agar $e \mathrm{pH}$ ajustado para $5,7 \pm 0,1$. Os mejos foram autoclavados a $121 \circ \mathrm{C}$ por 15 minutos a 1.5 atm. 0 delineamento experimental utilizado em todos os experimentos foi - inteiramente casualizado. Para efeito de analise estatistica, os dados relativos ao peso e contagem, foram transformados en $\sqrt{x+0,5}$.

A irradiaça dos diferentes materiais foi realizada com raios gama da fonte ${ }^{\infty}$ Co do CENA-USP.

3.2. Procedimentos especificos

3.2.1. Efeito de diferentes concentraçôes de CIN e IAA na formação de calos e embrióldes em tecido nucelar (Experimento 1 )

Os meios constituiram-se basicamente do meio MT suplementado com $50 \mathrm{~g} / 1$ de sacarose, $500 \mathrm{mg} / 1$ de extrato 
de malte (EM), contendo diferentes concentraçes dos reguladores de crescimento. Foram testadas todas as combinaços das concentraçbes de $0,0,1,0,5$ e $1,0 \mathrm{mg}$ dos reguladores de crescimento IAA e CIN, totalizando 16 meios de cultura diferentes. Foram inoculados 15 nucelos por placa de Petri, contendo $40 \mathrm{ml}$ de meio de cultura, com quatro repetiçoes por meio de cultura.

As culturas foram mantidas em condiçes de escuro (BOD) a temperatura de $24 \pm 1 \cdot \mathrm{C}$ e no mesmo meio de cultivo ate a avaliação.

A avaliaçăo foi realizada apos 8 semanas do inficio do cultivo dos nucelos. Foram obtidas as porcentagens de nucelos responsivos, isto é, nucelos que formaram embribides elou calos e o número medio de embríbides por nucelo em cada tratamento. Os resultados estão expressos como as medias obtidas das quatro repetiçós.

3.2.2. Efeito de diferentes melos de cultura na formaçăo de calos e embribides em tecido nucelar (Experimento 2 )

Estudos complementares foram realizados com a finalidade de se obter um melo de cultura com maior capacidade de formação de calos nucelares embriogenicos.

Neste ensaio, estudou-se trés meios de cultura constituidos do meio basico MT sem reguladores de 
crescimento, meio MT suplementado com $\operatorname{CIN}(0,1 \mathrm{mg} / \mathrm{l})$ e IAA $(1,0 \mathrm{mg} / 1)$ e meio MT suplementado com BAP $(10 \mathrm{mg} / 1)$. Todos os meios receberam adiça de $50 \mathrm{~g} / 1$ de sacarose e 500 $m g / 1$ de EM.

Foram inoculados 25 nucelos por placa de petri, contendo $40 \mathrm{ml}$ de meio de cultura. Sete repetiçes foram realizadas para cada tratamento.

As culturas foram mantidas no escuro (BOD), a temperatura de $24 \pm 1 \circ \mathrm{C}$ no mesmo meio de cultivo ate a úl tima avali işão.

As avaliaçoses foram realizadas após 8 a 12 semanas de cultivo. Foram obtidas as porcentagens de nucelos responsivos para formaça de calos elou embribides e - número médio de embrioides por nucelo em cada tratamento. Os resultados estão expressos como as medias obtidas das sete repetiços.

3.2. 3. Induçăo de embriogenese somática em calos nucelares (Experimento 3 )

os calos nucelares, obtidos em meio de culturaMT, suplementado com BAP (10 $\mathrm{mg} / \mathrm{l})$ (Experimento 2), foram inoculados em meio MT contendo diferentes açúcares e diferentes concentraçós de EM, como listados a seguir: 


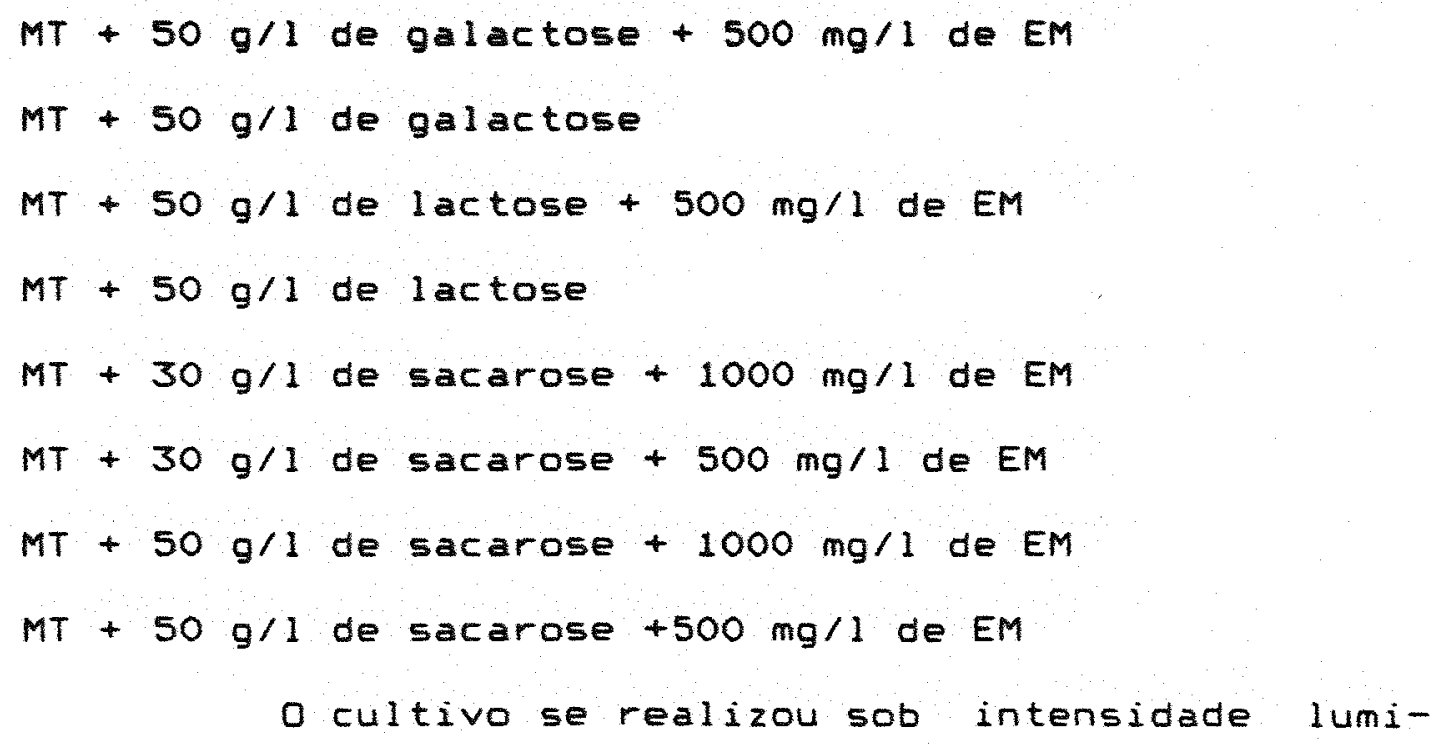

o cultivo se realizou sob intensidade luminosa de 3000 Iux, fotoperiodo de 16 horas de luz e a temperatura de $27 \pm 1 \cdot \mathrm{C}$.

Foram realizadas dez repetiçós para cada tratamento. Cada repetiçăo era composta por um tubo de ensaio contendo $10 \mathrm{ml}$ de meio de cultura onde foram inoculados $20 \mathrm{mg}$ de calo.

A avaliação foi realizada apos 40 dias fazendo-se a contagem do número de embrioides, no estadio cotiledonar e embrioides em diferentes outros estadios (globular, cordiforme e torpedol, por cultura com auxilio do estereo-microscopio.

3.2.4. Efeito de diferentes concentraç̧es de CIN e IAA no desenvol vimento de plantas a partir de embribides (Experimento 4 ) 
mentado com $50 \mathrm{~g} / 1$ de lactose e $500 \mathrm{mg} / \mathrm{l}$ de EM (Experimento 3), no estadio cordiforme $(2-3 \mathrm{~mm})$ foram inoculados individualmente em tubos de ensaio, contendo $10 \mathrm{ml}$ de meio de cultivo composto do meio MT suplementado com $50 \mathrm{~g} / \mathrm{l}$ de sacarose, $500 \mathrm{mg} / 1$ de $\mathrm{EM}$, contendo diferentes concentraçzes dos reguladores de crescimento CIN e IAA. Foram estudadas todas as combinaçoes das concentraçzes de $0 ; 0,1 ; 0,5$ e 1,0 $\mathrm{mg} / \mathrm{l}$ dos reguladores de crescimento, totalizando 16 tratamentos. o cultivo foi realizado sob intensidade luminosa de 3000 lux, fotoperiodo de 16 horas a a temperatura de $27 \pm$ $1 \cdot C$

Cada tratamento era composto de um número diferente de repetiçoses. A avaliaça foi realizada apos 60 dias da inoculaçăo dos embrioides. Foram obtidas as porcentagens de plantas normais, de anormalidades e a porcentagem de enraizamento em cada tratamento.

3.2.5. Efeito de diferentes meios de cultura na proliferaçăo de calo de embribides em calos obtidos em meio MT básico com reguladores de crescimento (Experimento 5$)$

Calos embriogenicos, obtidos em meio MT basico (suplementado com $50 \mathrm{~g} / 1$ de sacarose e $500 \mathrm{mg} / 1$ de EM) (Experimento 2), foram inoculados em meio basico de cultura contendo $1 \mathrm{mg} / \mathrm{l}$ de CIN e $1 \mathrm{mg} / 1$ de IAA, $50 \mathrm{~g} / \mathrm{l}$ de sacarose e 
$500 \mathrm{mg} / \mathrm{l}$ de EM para que se proliferassem mais rapidamente. Após o periodo de subcultivo de 4 semanas e, posteriormente, foram subcultivados tres vezes em meio MT sem reguladores de crescimento. Estes calos foram inoculados em meios de cultura com diversos tipos de suplementaçes. Estes meios eram: MT + $50 \mathrm{~g} / 1$ de sacarose, MT + $50 \mathrm{~g} / 1$ de sacarose, 500 $m g / 1$ de EM e as combinaçoses das concentraçbes de $0 ; 0,1$; 0,5 e $1,0 \mathrm{mg} / 1$ de CIN e IAA; MT + $50 \mathrm{~g} / 1$ de lactose; MT + 50 $9 / 1$ de galactose: $M T+50 \mathrm{~g} / 1$ de sacarose + BAP $(10 \mathrm{mg} / 1)$ e EM ( $500 \mathrm{mg} / 1)$, perfazendo-se um total de 20 tratamentos. Foram inoculados $20 \mathrm{mg}$ de calos em tubos de ensaio contendo $10 \mathrm{ml}$ de meio de cultura, com dez repetiçőes por tratamento. o cultivo realizou-se sob intensidade luminosa de 3.000 lux, fotoperiodo de 16 horas de luz e temperatura de $27 \pm 1 \circ \mathrm{C}$. Quarenta dias apos o infcio do cultivo, realizou-se a avaliaçá pesando-se os calos (peso fresco) e contando-se 0 número de embribides obtidos por calo. A contagem do numero de embrioides foi feita com auxilio do microscópio estereoscopico.

3.2.6. Verificação do fenomeno da habituação em calos nucelares (Experimento 6)

o objetivo deste experimento era verificar a ocorrencia da habituação em calos nucelares, frequentemente 
observada em outros cultivares de Citrus (SPIEGEL-ROY \& KOCHBA, 1975).

Calos do ev. Pera foram subcultivados por 6 passagens de 4 semanas cada uma, nos seguintes meios de cultivo (Experimento 5): $M T+\operatorname{CIN}(0,1 \mathrm{mg} / 1)+$ IAA $(0,5$ $\mathrm{mg} / 1), M T+\operatorname{CIN}(0,5 \mathrm{mg} / 1)+\operatorname{IAA}(0,5 \mathrm{mg} / 1), M T+\operatorname{CIN}(1,0$ $\mathrm{mg} / 1)+\operatorname{IAA}(0 \mathrm{mg} / 1), M T+\operatorname{CIN}(1,0 \mathrm{mg} / 1)+\operatorname{IAA}(0,1 \mathrm{mg} / 1)$, $M T+\operatorname{CIN}(1,0 \mathrm{mg} / 1)+\operatorname{IAA}(0,5 \mathrm{mg} / 1)$ e $M T+B A P(10 \mathrm{mg} / 1)$. Todos os meios foram suplementados com $50 \mathrm{~g} / 1$ de sacarose e $500 \mathrm{mg} / 1$ de $E M$

Subsequentemente, uma parte destes calos continuou a ser subcultivada nos mesmos meios de cultivo e outra parte foi inoculada em meio básico MT, suplementado com $50 \mathrm{~g} / 1$ de sacarose e $500 \mathrm{mg} / \mathrm{l}$ de EM sem requladores de crescimento. Estes calos foram subeultivados por mais 3 subcultivos de 4 semanas cada um e um subcultivo com 45 dias. Ao final do ultimo subcultivo, obteve-se o peso fresco dos calos subcultivados em meio basico MT e em meio com reguladores de crescimento.

Foram realizadas 10 repetiçoes para cada tratamento. Cada repetição era composta por 1 tubo de ensaio contendo $10 \mathrm{ml}$ de meio de cultura e inicialmente, $20 \mathrm{mg}$ de calo. O cultivo foi realizado sob fotoperiodo de 16 horas de luz, intensidade luminosa de 3000 lux e a temperatura de $27 \pm 1 \cdot C$. 


\title{
3.2.7. Efeito de diferentes concentraços de BAP e
}

\author{
NAA na indução de brotaçBes adventicias \\ (Experimento 7 )
}

o objetivo deste experimento era estudar o desenvolvimento de brotaçoes adventleias, a partir de cotiledones de embrizes nucelares do $C V$. Pera $(C$. sinensis osbeck), uma vez que, estes sáo obtidos de tecido somatico e, portanto, possuem o mesmo genotipo da planta mae $e$, alem disto, por serem obtioos in vitro, estes explantes nao necessitam de assepsia.

Os nucelos foram inoculados em meio MT, suplementado com $50 \mathrm{~g} / 1$ de sacarose e $500 \mathrm{mg} / 1$ de EM e mantidos em condiçoses de fotoperlodo de 16 horas de luz, a temperatura de $27 \pm 1 \circ \mathrm{C}$ sob intensidade luminosa de 3000 lux. Apos aproximadamente $3-4$ semanas, comecaram a surgir os embriós nucelares. Estes embribides foram individualizados e transferidos para o mesmo meio de cultura fresco. Apos 3-4 semanas, estes embribides atingiram o estadio cotiledonar expandido. Os cotiledores foram extraldos e divididos longitudinalmente en duas partes, sob condiçoses assepticas com auxilio de pinça e bisturi. Estas partes foram inoculadas em meio básico MT, suplementado com $30 \mathrm{~g} / 1$ de sacarose e todas as combinacbes das concentraçós de 0 ; 0,$5 ; 1,0 ; 1,5 ; 2,0 ; 2,5$ e $3,0 \mathrm{mg} / 1$ de BAP e NAA.

o cultivo foi realizado, inicialmente, por duas 
semanas sob condiça de 24 horas de escuro (BOD) e a temperatura de $24 \pm 1 \cdot \mathrm{C}$. Subsequentemente, o cultivo foi realizado sob intensidade luminosa de 3000 lux, fotoperiodo de 16 horas de luz a temperatura de $27 \pm 1 \cdot C$.

Foram inoculados 3 explantes por tubo de ensaio contendo $10 \mathrm{ml}$ de meio de cultura e tres repetiçes foram realizadas para cada tratamento.

A avaliação foi realizada apos 90 dias do inficio do cultivo dos cotiledones, obtendo-se a porcentagem de explante responsivo e o número medio de brotaçbes por explante responsivo.

3.2.8. Efeito de diferentes concentraçóes de BAP na multiplicação de brotaçôes adventicias (Experimento 8$)$

Nesse experimento, brotaçoses 11,0 a $1,5 \mathrm{~cm}$ de altura) provenientes de gemas adventicias, obtidas a partir de cotiledones inoculados em meio MT, suplementado com 30 $\mathrm{g} / 1$ de sacarose, $0,5 \mathrm{mg} / 1$ de BAP e $1,0 \mathrm{mg} / 1$ de NAA (Experimento 7) foram individualizadas em tubos de ensaio contendo meio MT, $30 \mathrm{~g}$ de sacarose e as concentraçós de $0 ; 1,0$; 2,$0 ; 3,0 ; 4,0$ e $5,0 \mathrm{mg} / 1$ de $\mathrm{BAP}$.

o cultivo foi realizado sob intensidade luminosa de $3000 \mathrm{lux}$, fotoperiodo de 16 horas a temperatura de $27 \pm 1 \cdot \mathrm{C}$. 
Foran realizadas 8 repetiçóes para cada tratamento sendo que cada repetiça era constitulda de uma brotaça inoculada em tubo de ensaio contendo $10 \mathrm{ml}$ de meio de cultura. A avaliaça foi realizada 60 dias apos a inoculaçao dos explantes. obteve-se a porcentagem de explantes que produziram gemas adventicias e o numero medio de gemas adventicias por explante.

3.2.9. Efeito de diferentes reguladores de crescimento no enraizamento das brotaçzes adventicias (Experimento 9 )

Brotaçōes adventicias $(1,0$ a $1,5 \mathrm{~cm})$ obtidas em meio básico MT suplementado com $0,5 \mathrm{mg} / 1$ de BAP e 1,0 mg/l de NAA (Experimento 7) e multiplicadas em meio contendo $3 \mathrm{mg} / 1$ de BAP (Experimento 8 ), foram inoculadas em meio básico MT, contendo $30 \mathrm{~g} / 1$ de sacarose e diferentes reguladores de crescimento e concentraçZes dos mesmos: NAA 10 ; $0,1 ; 0,3 ; 0,5 ; 1,0 ; 2,0 ; 3,0$ e $5,0 \mathrm{mg} / 1), \operatorname{GA} 3(1,0 ; 5,0$ e 10,0 $\mathrm{mg} / 1)$, NAA $(0,1 \mathrm{mg} / 1)+\operatorname{IBA}(2,0 \mathrm{mg} / 1), \mathrm{NAA}(1,0 \mathrm{mg} / 1)$ $+I B A(2,0 \mathrm{mg} / 1), \operatorname{NAA}(1,0 \mathrm{mg} / 1)+\operatorname{IBA}(5,0 \mathrm{mg} / 1)$, NAA $(5,0$ $m g / 1)+\operatorname{IBA}(2,0 \mathrm{mg} / 1)$ e $\operatorname{NAA}(5,0 \mathrm{mg} / 1)+\operatorname{BAP}(0,1 \mathrm{mg} / 1)$.

Tubos de ensaio, contendo $10 \mathrm{ml}$ de meio de cultura, foram inoculados com 3 brotaçes. Foram realizadas nove repetiçoes para cada tratamento.

- cultivo se realizou sob fotoperiodo de 16 
horas, sob intensidade luminosa de 3.000 lux e a temperatura de $27 \pm 1 \cdot C$.

A avaliaça foi realizada 4 semanas apos o inlcio do cultivo, obtendo-se a porcentagem media de plantas enraizadas em cada tratamento.

\subsubsection{Cortes histologicos (Experimento 10 )}

Os cortes histologicos foram realizados em cotiledones de embrizes nucelares com aproximadamente $3-4$ semanas de idade (estadio cotiledonar expandido), obtidos in vitro, e trinta dias apos a inoculaçăo dos cotiledones em meio de cultura para induzir a formação de brotaçoses adventicias.

As amostras do material para estudo anatsmico foram fixadas em FAA $50 \%$ (SASS, 1951).

A tecnica empregada para desidratação e emblocamento de material em parafina, corte e distensa das fitas em laminas, foi a indicada por SASS (1951). A espessura dos cortes variou entre $10 \mathrm{e} 12 \mathrm{\mu m}$. Seguiram-se a desparafinaça das láminas pelo xilol, a coloraçă do material pela safranina e "fast-green" (SASS, 1951), e, finalmente, a montagem en diafane.

Foram tiradas fotografias de material vivo e fotomicrografias de material preparado em laminas. 


\subsubsection{Obtenção de protoplastos}

\subsubsection{Isolamento de protoplastos}

(Experimento 11 )

Calos obtidos em meio MT, $50 \mathrm{~g} / 1$ de sacarose, $500 \mathrm{mg} / 1$ de extrato de malte e $10 \mathrm{mg} / 1$ de BAP (Experimento 2) foram subcultivados neste mesmo meio a intervalos de 4 semanas. Estes calos foram utilizados para o isolamento dos protoplastos. Foram estudados meios de maceraça e lavagem (Tabela 1 ) extraldos de 4 protocolos diferentes, utilizados em diversos cultivares de Citrus sinensis, inclusive cv. Pera. Estes meios foram denominados Meio 1, Meio 2, Meio 3 e Meio 4, apresentados na Tabela 1.

Foram inoculados $500 \mathrm{mg}$ de calo/10 $\mathrm{ml}$ de meio de maceração em placas de Petri com $9 \mathrm{~cm}$ de diametro. Foram realizadas duas repetiçóes por tratamento enzimático e por periodo de digestáo enzimatica, sendo que cada repetiçăo era representada por uma placa de Petri. A digestao enzimatica ocorreu em condiça de escuro a temperatura de $27 \pm$ $1 \circ \mathrm{C}$, a 25 rpm de agitação rotatória. As avaliaçós foram realizadas 5,10 e 15 horas após a inoculação dos calos em meio enzimático.

3.2.11.2. Purificação dos protoplastos

Após cada periodo de incubação, a suspensăo, composta por meio enzimatico, protoplastos e calos, foi fil- 
trada en peneiras com tela de Nylon com poros de $30 \mathrm{~mm}$ e 25

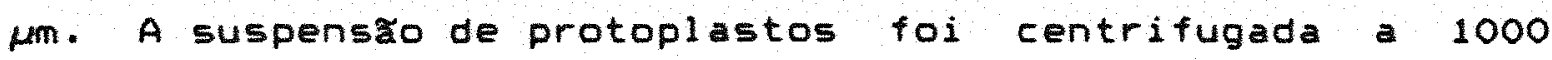
rpm durante 5 minutos.

- sobrenadante foi descartado e aos protoplastos precipitados foram acrescentados $10 \mathrm{ml}$ do meio de lavagem (Tabela 1 ). Os protoplastos foram ressuspensos cuidadosamente com pipeta de Pasteur e centrifugados novamente. Esta operacáo foi repetida por mais duas vezes.

Tabela 1. Meios de maceraçăo e de purificaçăo (lavagem) de acordo com 4 diferentes protocolos.

MEIO 1 (GOLDMAN, 1988)

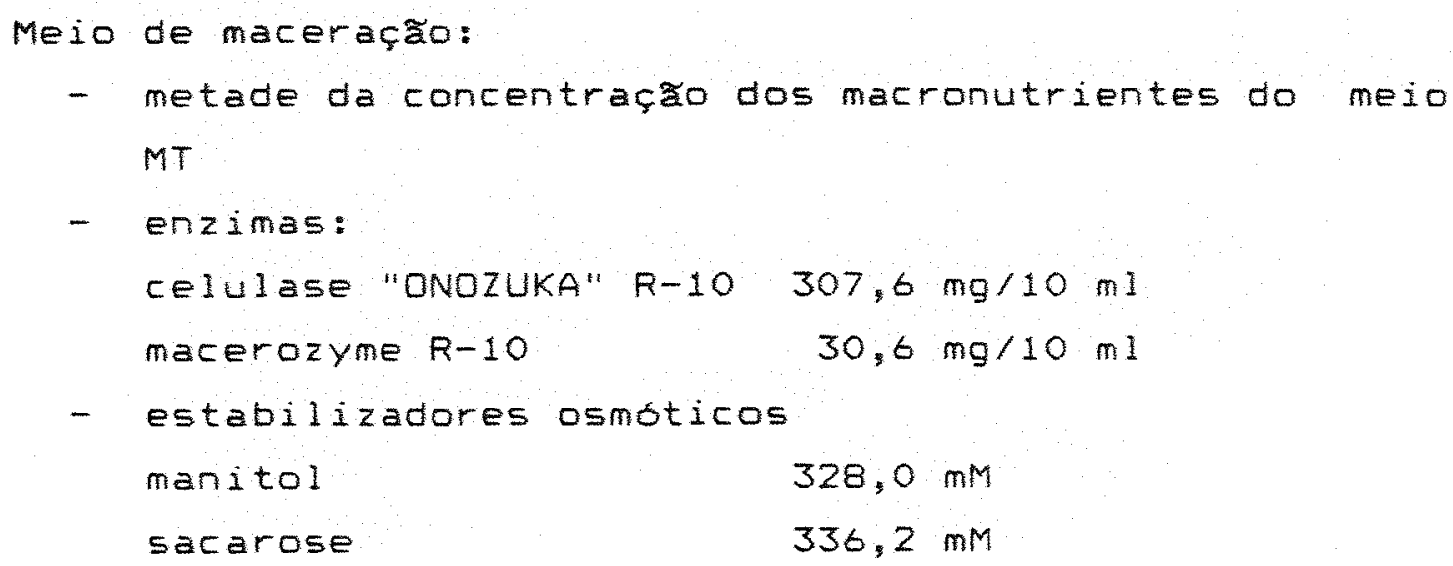

Meio de lavagem:

- meio MT completo

- estabilizadores osmóticos:

$\begin{array}{ll}\text { manitol } & 328,0 \mathrm{mM} \\ \text { sacarose } & 336,0 \mathrm{mM}\end{array}$


Tabela 1. Continuaçao.

MEIO 2 (VARDI et alii, 1982)

Meio de maceraça:

Metade dos macronutrientes do meio MT

- enzimas:

$\begin{array}{ll}\text { pectinase } & 30 \mathrm{mg} / 10 \mathrm{ml} \\ \text { celulase "ONOZUKA" R-10 } & 20 \mathrm{mg} / 10 \mathrm{ml} \\ \text { driselase } & 10 \mathrm{mg} / 10 \mathrm{ml} \\ \text { estabilizadores osmóticos } \\ \text { sacarose } & 0,14 \mathrm{M} \\ \text { manitol } & 0,56 \mathrm{M}\end{array}$

Meio de lavagem:

Meio MT completo

- estabilizadores osmóticos

$\begin{array}{ll}\text { sacarose } & 0,3 \mathrm{M} \\ \text { manitol } & 0,3 \mathrm{M}\end{array}$

MEIO 3 (KOBAYASHI et alii, 1987)

Meio de maceraça:

metade da concentração dos macronutrientes do meio MT Enzimas:

celulase "ONOZUKA" R-10 $30 \mathrm{mg} / 10 \mathrm{ml}$

macerozyme R-10 $30 \mathrm{mg} / 10 \mathrm{ml}$

oriselase $\quad 1,0 \mathrm{mg} / 10 \mathrm{ml}$

Estabilizadores osmóticos:

manitol $0,7 \mathrm{M}$

Meio de lavagem:

meio MT completo 
Tabela 1. Continuaça.

Estabilizadores osmóticos:

$\begin{array}{lll}\text { manitol } 0,6 \mathrm{M} & \text { (1a. e } 2 \mathrm{a} \text { lavagem) } \\ \text { manitol } 0,45 \mathrm{M} & \text { (3a. lavagem) }\end{array}$

MEIO 4 (SPIEGEL-ROY \& VARDI, 1984)

Meio de maceração:

metade da concentraçăo dos macronutrientes do meio MT

- enzimas

macerozyme $\mathrm{R}-10 \quad 30 \mathrm{mg} / 10 \mathrm{ml}$

celulase "ONOZUKA" $\mathrm{R}-10 \quad 20 \mathrm{mg} / 10 \mathrm{ml}$

driselase $10 \mathrm{mg} / 10 \mathrm{ml}$

- estabilizadores osmoticos:

sacarose $0,3 \mathrm{M}$

manitol $\quad 0,4 \mathrm{M}$

Meio de lavagem:

meio MT completo

sacarose $0,3 \mathrm{M}$

manitol $0,3 \mathrm{M}$ 


\subsubsection{Verificaça do rendimento dos protoplastos durante o processo de isolamento}

Após a purificaçáo dos protoplastos, a verificaça do rendimento foi realizada, retirando-se duas amostras de cada repetiço por tratamento, após cada periodo de digestáo enzimatica e fazendo-se a contagem do número de protoplastos em 8 campos da camara de Neubauer para cada amostra. o resultado final fol expresso como o número medio de protoplastos por grama de calo.

3.2.12. Verificaçåo da viabilidade dos protoplastos (Experimento 12$)$

A avaliação dos protoplastos viaveis foi realizada, utilizando-se o metodo de coloraçăo com diacetato de fluorescelna, descrito por WIDHOLM (1972).

Estudou-se o efeito de trés diluiçres de diacetato de fluoresceina em meio de lavagem. As diluiçós foram de 1:50, 1:100 e 1:150 da solução estoque de diacetato de fluoresceina e meio de lavagem, respectivamente. Uma allquota de $1 \mathrm{ml}$ do corante dilusdo fol adicionada a uma aliquota de igual volume da suspensão de protoplastos.

A contagem realizou-se 5 minutos após a inoculaçăo do corante na suspensão de protoplastos. 


\section{Imediatamente apos o isolamento e purifica-} qăo dos protoplastos, foi verificada a viabilidade dos mesmos. Tres repetiços foram realizadas para cada diluiça do corante, sendo que duas amostras foram obtidas de cada repetiçăo, contando-se o número de protoplastos em 8 campos da camara de Neubauer. Obteve-se o número total de protoplastos atraves da contagem en camara de Neubauer, em microscópio otico comum posterior contagem en microscopio de fluorescencia. Verificou-se desta forma, a porcentagem de protoplastos viáveis.

3.2.13. Cultivo dos protoplastos (Experimento 13 )

Após o processo de purificação, a densidade dos protoplastos foi ajustada para $10^{5}$ e $2 \times 10^{5}$ protoplastos/ m1. O meio de cultura era constituido do meio básico MT, complementado com diferentes concentraçóes de manitol e sacarose, conforme descrito na Tabela 2.

Foram adicionados $2 \mathrm{ml}$ de meio $11 q u i d o, d e$ cada tratamento, aos protoplastos precipitados nos tubos de centrifuga. Posteriormente, $2 \mathrm{ml}$ de meio de cultura, contendo $1,2 \%$ de agarose $(40 \cdot \mathrm{C})$, foram adicionados em cada frasco contendo uma suspensão de meio de cultura e protoplastos. Desta forma, o volume foi completado para $4 \mathrm{ml}$ e a concentraçá final de agarose no meio de cultura, ficou sendo de $0,6 \%$ (SPIEGEL-ROY \& VARDI, 1984). Assim como, as densidades 
de plaqueamento de protoplastos ficaram ajustadas em $5 \times 10^{4}$ e $10^{5}$ protoplastos/ml. As suspensoes, de protoplastos e meio de cultura, foram cuidadosamente homogeneizadas e inoculadas em placas de petri com $5 \mathrm{~cm}$ de diametro, com auxilio da pipeta de Pasteur.

Tabela 2. Mejos de cultura e densidade de plaqueamento utilizadas no cultivo de protoplastos isolados a partir de calos embriogenicos do cV. Pera.

\begin{tabular}{cccc}
\hline Meios de & Manitol & Sacarose & Densidade \\
cultura & $($ M) & $($ M) & $5 \times 10^{4}$ \\
\hline 1 & 0,15 & 0,15 & $5 \times 10^{4}$ \\
3 & 0,25 & 0,15 & $5 \times 10^{4}$ \\
4 & 0,15 & 0,25 & $5 \times 10^{4}$ \\
5 & 0,25 & 0,25 & $10^{5}$ \\
6 & 0,15 & 0,15 & $10^{5}$ \\
7 & 0,25 & 0,15 & $10^{5}$ \\
8 & 0,15 & 0,25 & $10^{5}$ \\
9 & 0,25 & 0,25 & $5 \times 10^{4}$ \\
10 & 0,15 & 0,15 & $5 \times 10^{4}$ \\
11 & 0,45 & 0,15 & $5 \times 10^{4}$ \\
12 & 0,15 & 0,25 & $5 \times 10^{4}$ \\
13 & 0,45 & 0,25 & $10^{5}$ \\
14 & 0,15 & 0,15 & $10^{5}$ \\
15 & 0,45 & 0,15 & $10^{5}$ \\
16 & 0,15 & 0,25 & $10^{5}$ \\
\hline
\end{tabular}


o cultivo realizou-se a temperatura de $24 \pm$ 1.C sob condição de escuro.

Tres repetiçbes foram realizadas para cada tratamento.

Observaçós foram realizadas semanalmente com auxilio do microscopio invertido.

\subsubsection{Radiossensitividade dos diferentes materials}

\section{2 .14 .1 . Radiossensitividade dos tecidos} nucelares (Experimento 14)

Neste experimento, os nucelos foram extraidos de acordo com o que foi descrito no item 3.1 (Procedimentos gerais). O meio de cultura utilizado foi o meio básico MT suplementado com $50 \mathrm{~g} / 1$ de sacarose e $500 \mathrm{mg} / 1$ de EM.

Cada parte do tecido nucelar, extraldo de uma semente, fol inoculada em um tubo de ensaio contendo $10 \mathrm{ml}$ do meio de cultura e imediatamente apos a inoculaçăo foram irradiados juntamente com o meio de cultura com as doses de radiaçăo gama de: $0 ; 20,0 ; 40,0 ; 60,0 ; 80,0 ; 100,0 ; 120,0$; 140,0 e 160,0 Gy a uma taxa de dose de 970 Gy/h. Foram realizadas 28 repetiçóes para cada tratamento. O cultivo se realizou sob fotoperiodo de 16 horas, temperatura de $27 \pm 1{ }^{\circ} \mathrm{C}$, sob intensidade luminosa de 3.000 lux.

As avaliaçóes realizaram-se após 6 e 8 semanas de cultivo, fazendo-se a contagem do número de embrió- 
des por nucelo responsivo e o numero de nucelos responsivos.

\subsubsection{Radiossensitividade dos calos nucelares (Experimento 15 )}

Calos provenientes de nucelos cultivados em meio MT, suplementado com $50 \mathrm{~g} / 1$ de sacarose, $500 \mathrm{mg} / \mathrm{l}$ de EM e $10 \mathrm{mg} / 1$ de BAP, e subcultivados a intervalos de 4 semanas foram irradiados com doses de $0 ; 30,0 ; 60,0 ; 90,0$; $120,0,150,0$ e 180,0 Gy,com taxa de dose de 970 Gy/h.

Cinco tubos de ensaio, contendo calos com 4 semanas de subcultivo e mantidos no escuro à temperatura de $24 \pm 1 \circ \mathrm{C}$ foram irradiados em cada dose. Após o tratamento mutagênico com radiaçăo gama, sob condiçóes assepticas, os calos irradiados com a mesma dose foram agrupados em uma placa de Petri, de onde foram retiradas porçbes de $25 \mathrm{mg}$ de calos e inoculadas em tubos de ensaio contendo $10 \mathrm{ml}$ do meio MT, adicionado de $50 \mathrm{~g} / \mathrm{l}$ de lactose e $500 \mathrm{mg} / \mathrm{l}$ de $\mathrm{EM}$. cultivo se realizou sob fotoperiodo de 16 horas, intensidade luminosa de 3.000 lux e temperatura de $27 \pm 1 \circ \mathrm{C}$. Realizaramse 10 repetiçôes para cada tratamento, isto 6,10 tubos de ensaio contendo $25 \mathrm{mg}$ de calo. Quarenta dias apos o tratamento mutagénico, realizou-se a avaliaçao, pesando-se os calos e fazendo-se a contagem do número de embribides por calo. 
3.2.14.3. Radiossensitividade em protoplastos (Experimento 16)

Protoplastos isolados de calos embriogenicos, obtidos atraves de nucelos inoculados em meio MT contendo $50 \mathrm{~g} / 1$ de sacarose, $500 \mathrm{mg} / 1$ de EM e $10 \mathrm{mg} / 1$ de BAP, foram irradiados com as doses de $0,15,0,30,0,45,0$ e 60,0 Gy a uma taxa de dose de 290 Gy/h. Quarenta gramas de calos embriogenicos foram inoculados em $80 \mathrm{ml}$ de soluçăo enzimática. Após a primeira lavagem, uma aliquota de $2,5 \mathrm{ml}$ da suspensao de protoplastos foi inoculada en tubo de ensaio. Tres tubos de ensaio contendo $2,5 \mathrm{ml}$ da suspensão de meio de lavagem e protoplasto foram irradiados em cada dose.

Apos a irradiaça, os protoplastos foram lavados mais duas vezes e ressuspensos novamente em $2,5 \mathrm{ml}$ de meio de lavagem com uma densidade final de $2 \times 10^{5}$ protoplastos/ml e incubados por 24 horas, neste mesmo meio, em condiçós de escuro, à temperatura de $24 \pm 1 \cdot \mathrm{C}$. Vinte e quatro horas apos o tratamento mutagenico, estudou-se a viabilidade dos protoplastos atraves da tecnica de coloraçăo com diacetato de fluoresceina descrita no item 3.2.12. De cada uma das tres repetiçzes por tratamento, uma amostra foi retirada e misturada a um volume igual do corante, diacetato de fluoresceina, previamente dilusdo em meio de lavagem na proporçăo de 1:150, ou seja, $0,1 \mathrm{ml}$ do corante para $15 \mathrm{ml}$ da solução de lavagem. Aguardou-se 5 minutos para que ocorresse a reação com o corante e a fluoresceina fosse liberada. 
Com auxilio da camara de Neubauer e do miscroscopio de fluorescencia, realizou-se a contagem do numero de protoplastos viaveis.

Na camara de Neubauer, contou-se para cada amostra o número de protoplastos en 8 campos e tirou-se uma media. Obteve-se, desta forma, a porcentagem de protoplastos viáveis após exposiçăo as diferentes doses de radiaçăo gama.

3.2.14.4. Radiossensitividade en cotiledones de embribes nucelares (Experimento 17 )

Embribes nucelares, no estadio cotiledonar expandido ( 3 a 4 semanas de idade), obtidos in vitro, for am irradiados com raios gama com as doses de $0,10,0,20,0$; 30,$0 ; 40,0 ; 50,0 ; 60,0,70,0 ; 80,0$ e 90,0 6y a uma taxa de dose de 970 Gy. Apos a irradiaça, as follhas cotiledonares foram extraidas e divididas longitudinalmente en duas partes iquais e 4 partes foram inoculadas em tubos de ensalo contendo meio MT suplementado com $30 \mathrm{~g} / 1$ de sacarose, 0,5 $\mathrm{mg} / 1$ de BAP e $1,0 \mathrm{mg} / 1$ de NAA. o cultivo se deu inicialmente, em condição de escuro, por 15 dias e posteriormente, sob intensidade luminosa de 3.000 lux, fotoperiodo de 16 horas e temperatura de $27 \pm 1 \circ \mathrm{C}$.

Foram realizadas 10 repetiças para cada tratamento. A avaliação realizou-se 90 dias apos o infeio do 
cultivo, obtendo-se a porcentagen de explantes responsivos e - número medio de brotaçbes adventicias por explante responsivo. 


\title{
4. RESULTADOS E DISCUSSÃO
}

\author{
4.1. Induçăo de calos e embritos somáticos a \\ partir de nucelos
}

4.1.1. Efeito de diferentes concentraçós de CIN E IAA (Experimento 1 )

Os resultados obtidos com o uso de diferentes concentraçBes de CIN e IAA e suas combinaçz̃es estão apresentados na Tabela 3 . Pode-se observar, que de uma forma geral, a aumento da concentração de IAA em todas as concentraçzes de CIN produziu um aumento na porcentagem de formacåo de calos a partir dos nucelos (Figura 1). A maior porcentagem $(66,67)$ para a formação de calos foi obtida no meio de cultura MT, suplementado com $0,1 \mathrm{mg} / 1$ de cinetina e $1,0 \mathrm{mg} / 1$ de IAA, e a menor porcentagem $(0 \%)$ foi obtida no meio de cultura MT sem suplementaça com reguladores de crescimento.

Quanto a formaçăo de embrioides, pode-se notar que, de uma forma geral, a porcentagem de nucelos res- 
ponsivos e número medio de embribides por nucelo diminuiu com o aumento da concentraça de IAA em todas as concentraçס̋es de CIN. 0 maior número de embrioides por nucelo foi obtido no meio de cultura suplementado com $1,0 \mathrm{mg} / 1$ de CIN e $0,0 \mathrm{mg} / 1$ de IAA. Pode-se observar tambem que os meios que proporcionaram as maiores porcentagens de nucelos responsivos $(60 \%)$, nå são os que produziram maior número de embribides por nucelos.

Os calos obtidos em todos os tratamentos apresentavam coloraça amarela, eram compactos e nao havia sinal de formação de embrioides a partir dos mesmos.

Os calos formaram-se por toda a superficie dos explantes e, eventualmente, a partir destes calos compactos proliferava uma massa de celulas de coloraça branca e de textura friavel. Houve a proliferaçăo de calo e embribides a partir do mesmo explante nos diferentes tratamentos e os calos proliferavam-se lentamente.

Estes dois tipos de calos foram observados no cultiva de ovulos inteiros do ev. Pera por GOLDMAN (1988), que sugeriu que a formaçă dos calos tivesse sido estimulada pelo fornecimento de reguladores de crescimento presentes em outros tecidos do óvulo. De fato, no presente trabalho, verificou-se que o fornecimento de reguladores ao meio de cultura estimulou a formaça de calos a partir do tecido nucelar, entretanto, os calos nå apresentavam caracteristicas embriogenicas como se desejava. 
Tabela 3. Efeito das diferentes concentraçBes de CIN e IAA, adicionadas a mejo MT, na formaça de calos e embribides no tecido nucelar, 8 semanas após a inoculação dos nucelos.

\begin{tabular}{|c|c|c|c|c|}
\hline \multicolumn{2}{|c|}{$\begin{array}{c}\text { Tratamentos } \\
\text { (mg/1) }\end{array}$} & $\begin{array}{c}\text { Prolife- } \\
\text { raça de } \\
\text { calos } \\
(\%)\end{array}$ & $\begin{array}{c}\text { Prolife- } \\
\text { raço de } \\
\text { embrioides } \\
(\%)\end{array}$ & \multirow{2}{*}{$\begin{array}{l}\text { No medio } \\
\text { de embrioides } \\
\text { /nucelo } \\
\text { ( } \pm 5) \\
1,34 \pm 0,28\end{array}$} \\
\hline $\mathrm{CIN}-\mathrm{O}, \mathrm{O}$ & + IAA-O,O & 0,00 & 33,34 & \\
\hline CIN-O,O & $+I A A-0,1$ & 40,00 & 54,84 & $1,13 \pm 0,84$ \\
\hline CIN-O,O & + IAA-0,5 & 26,67 & 40,00 & $0,43 \pm 0,14$ \\
\hline $\mathrm{CIN}-\mathrm{O}, \mathrm{O}$ & $+I A A-1,0$ & 26,67 & 27.05 & $0,50 \pm 0,04$ \\
\hline CIN-0,1 & + IAA-O, & 26,67 & 33,34 & $0,97 \pm 0,52$ \\
\hline CIN-O, 1 & $+I A A-0,1$ & 20,00 & 33,34 & $1,40 \pm 0,09$ \\
\hline CIN-O,1 & + IAA-0,5 & 46,67 & 33,34 & $0,70 \pm 0,52$ \\
\hline CIN-O, 1 & $+I A A-1,0$ & 66,67 & 26,67 & $0,40 \pm 0,09$ \\
\hline CIN-O, 5 & $+I A A-0,0$ & 6,67 & 60,00 & $1,20 \pm 0,66$ \\
\hline CIN-O, 5 & $+I A A-0,1$ & 22,20 & 55,56 & $1,34 \pm 0,56$ \\
\hline CIN-O, 5 & $+\quad I A A-0,5$ & 40,00 & 26,67 & $0,57 \pm 0,04$ \\
\hline CIN-0,5 & $+I A A-1,0$ & 57,13 & 20,00 & $0,34 \pm 0,09$ \\
\hline CIN $-1,0$ & + IAA-O,O & 20,00 & 46,67 & $1,97 \pm 0,14$ \\
\hline $\mathrm{CIN}^{-1}, \mathrm{O}$ & $+\quad I A A-0,1$ & 20,00 & 60,00 & $1,47 \pm 0,09$ \\
\hline $\mathrm{CIN}-1,0$ & $+I A A-0,5$ & 40,00 & 40,00 & $0,77 \pm 0,14$ \\
\hline CIN-1,O & $+I A A-1,0$ & 33,34 & 20,00 & $0,53 \pm 0,09$ \\
\hline
\end{tabular}


Nucelos cultivados en meio de cultura sem suplementaça com reguladores de crescimento, ná apresentaram formação de calos, mas foi observada somente a formaça de embribides, neste caso. Este fato está de acordo com o que foi verificado por KOCHBA et alii (1972), para cultivares Shamouti, Valencia e Marsh e por GOLDMAN (1988), para o cV. Pera.

Segundo Esan, citado por PASQUAL et alii (1988), a adiçăo das auxinas IAA, NAA e $2,4-D$ ao meio de cultura suprimiu significativamente ou completamente a embriogenese nucelar. PASQUAL et alii (1988) observaram que a adiçăo de $2,4-D$, em qualquer concentraçăo, aos nucelos mantidos no escuro, inibiu completamente a embriogenese, independentemente da presença de citocinina. Este mesmo fato foi observado por GOLDMAN (1988), para o cV. Pera. Entretanto, GMITTER \& MOORE (1986) obtiveram porcentagens entre 0 e $54 \%$ de ovulos produzindo embribides, em meio acrescido de $0,01 \mathrm{mg} / 1$ de 2,4-D. Estes autores trabalharam com varios cultivares e especies de Citrus, que diferiram bastante quando ao efeito do 2,4-D sobre a embriogenese.

No presente trabalho, verificou-se que a adição do IAA do meio de cultura não suprimiu completamente a embriogenese em nenhuma das concentraçbes utilizadas, porem, causou uma diminuiçăo do número medio de embriódes obtidos por nucelo (Figura 1), conforme aumentou sua concentração no meio de cultura. Entretanto, a porcentagem de nucelos res- 
ponsivos, em certas concentraçes de IAA, foi maior que a porcentagem encontrada em meio de cultura sem suplementaça com reguladores de crescimento.

A proliferação de embriódes, a partir dos embrioides ja presentes, foi evidenciada,principalmente, nos meios de cultura contendo cinetina. E possivel entao, que a cinetina esteja favorecendo a formaço de embriódes a partir de embribides imaturos, no presente trabalho. GMITTER \& MOORE (1985) observaram a formaça de embrióides, a partir dos embriódes já existentes, no cultivo de ovulos do cv. Marsh, em meio suplementado com daminozida, um inibidor da sintese de GA3. Estes autores verificaram que o número de embribides produzidos por ovulos responsivos aumentou consideravelmente no tratamento utilizado a concentraçăo 10 mg/l de daminozida, devido, principalmente, à formação de embribides a partir dos já existentes.

4.1.2. Efeito dos reguladores de crescimento CIN, IAA E BAP CExperimento 2

O efeito dos reguladores de crescimento CIN, IAA E BAP, adicionados do meio de cultura MT, sobre a formação de calos e embrioides, a partir de nucelos, está apresentado nas Tabelas 4 e 5 , em duas datas diferentes de avaliação.

A primeira avaliaçăo foi realizada 8 semanas 
após a inoculação dos nucelos em meio de cultura. Observase que nao houve a formacao de calos no meio MT, sen a suplementacáo de reguladores de crescimento. o meio suplementado con CIN e IAA resultou na maior porcentagem de nuce105 com calos. Porem, assim como foi observado no Experimento 1 (item 4.1 .1 ), estes calos eram compactos e nao apresentavam caracteristicas embriogenicas. O meio suplementado com $10 \mathrm{mg} / \mathrm{l}$ de BAP originou pequenos calos na extremidade micropilar dos nucelos (Figura 2). Estes calos eram friaveis e bastante soltos. Năo foi observada a formaça de embridides nestes calos durante o perlodo de avaliaça.

Apos 12 semanas de cultivo, observou-se um aumento na porcentagem (de 7,42 para $36,57 \%$ ) de nucelos responsivos quanto a formaçăo de calos no meio de cultura suplementado com BAP. Pequena proliferaça de celulas aparecia na extremidade micropilar dos nucelos, mas proliferavam-se rapidamente neste meio de cultura (Figura 3 ). Foi observada tambem uma pequena proliferação de celulas a partir de proembribides e embribides imaturos (regiao do hipocotilo) no meio MT, sem suplementaça com reguladores de crescimento.

Quanto a obtença de embrioides, diretamente do explante nucelar, observa-se que o meio MT, sem a suplementação com requladores de crescimento, foi o que resultou em maior numero de embribides/nucelo (Figura 4). 0 meio suplementado com BAP $(10 \mathrm{mg} / 1)$ resultou na formação de um número muito pequeno de embrioides/nucelo. 
Tabela 4. Efeito dos reguladores de crescimento CIN, IAA BAP, adicionados ao meio de cultura MT, na porcentagen de formaça de calos. Avaliaç⿸es 8 e 12 semanas apos o cultivo de nucelos.

\begin{tabular}{lcc}
\hline $\begin{array}{c}\text { Tratamentos } \\
(m g / 1)\end{array}$ & $\begin{array}{c}8 \text { semanas } \\
(\%)\end{array}$ & $\begin{array}{c}12 \text { semanas } \\
(\%)\end{array}$ \\
\hline$M T$ & 0,00 & 1,71 \\
$M T+$ CIN-0,1+IAA- 1,0 & 47,00 & $52,00 *$ \\
$M T+$ BAP-10,0 & 7,42 & $36,57 * *$ \\
\hline
\end{tabular}

* Calos não embriogenicos

* calos embriogenicos

Tabela 5. Efeito dos reguladores de crescimento CIN, IAA e BAP sobre o número médio de embrioides obtidos por nucelo. Avaliaços $\theta$ e 12 semanas apos o cultivo de nucelos.

\begin{tabular}{|c|c|c|}
\hline $\begin{array}{c}\text { Tratamentos } \\
\text { (mgli) }\end{array}$ & $\begin{array}{c}8 \text { semanas } \\
( \pm S)\end{array}$ & $\begin{array}{c}12 \text { semanas } \\
( \pm 5)\end{array}$ \\
\hline
\end{tabular}

$\begin{array}{lll}M T & 0,96 \pm 0,11 & 1,54 \pm 0,21 \\ M T+C I N-0,1+1 A A-1,0 & 0,65 \pm 0,26 & 0,92 \pm 0,17 \\ M T+B A P-10,0 & 0,03 \pm 0,04 & 0,05 \pm 0,07\end{array}$

A obtenção de calos embriogenicos em cv. Pera (C. sinensis) já havia sido relatada por PASQUAL et alii (1988) em óvulos cultivados em meio com requladores de cres- 
cimento, principalmente 2,4-D. Entretanto, 0 uso deste regulador de crescimento en cultura de tecido tem sido correlacionado com o aparecimento de aberraçóses cromossomicas (VARDI et alii, 1982; SPIEGEL-ROY et alii, 1983). GOLDMAN (1988) obteve calos embriogenicos deste cultivar sem a utilizacão de requladores de crescimento. Entretanto, estes calos foram obtidos cerca de 7 meses apos a inoculacão dos explantes en meio de cultura, na regiáo do hipocótilo dos embrioides formados a partir dos nucelos.

A formação de calos embriogenicos,em melo sem suplementaça com reguladores de crescimento, fol obtida para diferentes cultivares e especies de Citrus (KOCHBA et alii, 1972; VARDI et alii, 1982). Estes calos proliferavam-se lentamente e apresentavam uma composiça bastante neterogênea.

No presente trabalho, observou-se a formaça de calos extremamente pequenos a partir de embrioides imaturos na região do hipocotilo em uma porcentagem pequena dos nucelos $(1,71 \%)$ em meio básico MT sem suplementaço com reguladores de crescimento. Alem disto, estes calos tinham um crescimento lento quando subcultivados neste mesmo meio de cultura.

o meio MT, suplementado com $10 \mathrm{mg} / 1$ de $B A P$, produziu calos que se proliferavam rapidamente e com caracterlsticas embriogenicas. KOBAYASHI et alii (1984) induziram a formaçăo de calos em onze cultivares de citrus em 
meio de cultura com BAP $(10 \mathrm{mg} / 1)$, após aproximadamente 80 dias de cultivo. Segundo estes autores, estes calos foram mantidos por cinco anos de subcultivo no meio de cultura e conservaram seu potencial embriogenic o. Estudos realizados sobre o formato das folhas, padrbes de cromatografia, padraes de bandamento de isoenzimas e número de cromossomos em plantas regeneradas a partir destes calos e a partir de protoplastos obtidos destes calos embriogenicos ná revelaram nenhuma variaçăo nas caracteristicas examinadas. A uniformidade observada entre as plantas regeneradas era identica a encontrada nas plantas nucelares.

Assim sendo, este meio de cultura constituiuse em um meio bastante adequado para a inducão e proliferação de calos nucelares. A obtençao de calos embriogenicos, em grande quantidade e em pequeno espaço de tempo, era de importancia fundamental para o prosseguimento deste trabaIho, pois estes se constituiam na materia prima para o isolamento de protoplastos e para os estudos sobre radiossensitividade em calos embriogenicos.

4.2. Indução de embriogenese somática em calos nucelares (Experimento 3)

Os resultados, obtidos com o uso de meios de cultura suplementados com diferentes carboidratos e dife- 
rentes concentraç̋es de EM, estao apresentados na Tabela 6. Pode-se notar que houve um estimulo sensivel na formaça de embrioides (em diferentes estadios de desenvolvimento), em calos obtidos no meio MT contendo BAP (10 $\mathrm{mg} / \mathrm{l})$, quando os meios de cultura utilizados para induça da embriogenese continham galactose e lactose (Figuras 5 a 8 ). O EM beneficiou a embriogenese nos meios suplementados com galactose e lactose.

Nos meios de cultura, contendo sacarose, verificou-se que a concentração de $30 \mathrm{~g} / 1$ deste açucar e de 1000 mg/l de EM produziram o maior número de embriódes.

A avaliaçå foi realizada, levando-se em conta os embridides presentes em todos os estádios de desenvolvimento, isto é, globular, cordiforme, torpedo e cotiledonar (figura 9).

Defeito estimulador da galactose e lactose sobre a embriogenese foi interpretado em relaça a interaça destes carboidratos com a biossintese de IAA. A galactose age diretamente inibindo a sintese de IAA ou indiretamente, estimulando a formação do etileno que, en al tos niveis, suprime a biossintese de auxinas (KOCHBA et alii, 1978; BENHAYYIM \& NEUMANN, 1983).

KOCHBA et alii (1982), estudando o efeito de vários carboidratos sobre a embriogenese em calos habituados de diferentes cultivares e especies de Citrus, verificaram que as mais baixas concentraçóes de sacarose $(B, 16$ e $32 \mathrm{~mm})$ 
favoreceram a embriogenese nos diferentes genotipos estudados. Entretanto, o efeito estimulador da galactose e lactose sobre a embriogenese foi pronunciado, em todos os genotipos estudados, en concentraçzes de 32 ou $64 \mathrm{mM}$ ate $256 \mathrm{mM}$.

Tabela 6. Efeito de diferentes carboidratos sobre a embriogénese en calos nucelares, obtidos em meio MT, suplementado com BAP $(10 \mathrm{mg} / 1)$. Avaliação 40 dias apos cultivo.

\begin{tabular}{|c|c|c|}
\hline $\begin{array}{c}\text { Meio de cul tura } \\
(\mathrm{mg} / 1)\end{array}$ & $\begin{array}{c}\text { No medio } \\
\text { de embrioides } \\
\text { maduros/ } \\
\text { calo* }\end{array}$ & $\begin{array}{l}\text { No medio } \\
\text { de embrioides } \\
\text { em diferentes } \\
\text { estádios/calo* }\end{array}$ \\
\hline$M T+g a 1$ actose $-50.000+E M-500$ & $1,50 \mathrm{~b}$ & $1.175,25 a$ \\
\hline$M T+1$ ectose $-50.000+E M-500$ & $4,00 \mathrm{~b}$ & $1.316,25 \mathrm{a}$ \\
\hline$M T+g a l a c t o s e-50.000$ & $2,25 \mathrm{~b}$ & $691,75 \mathrm{ab}$ \\
\hline$M T+1 a c$ tose -50.000 & $5,75 \mathrm{~b}$ & $705,00 a b$ \\
\hline$M T+s a c a r o s e-30.000+E M-1000$ & $19,00 \mathrm{a}$ & $142,00 \mathrm{bc}$ \\
\hline$M T+5$ ecarose $-30.000+E M-500$ & $13,00=$ & $27,75 c$ \\
\hline$M T+5$ acarose $-50.000+E M-1000$ & $15,75 \mathrm{a}$ & $25,50 \mathrm{c}$ \\
\hline$M T+s a c a r 0 s e-50.000+E M-500$ & $11,25 \mathrm{a}$ & $41,50 \mathrm{c}$ \\
\hline
\end{tabular}

Medias seguidas de letras iguais não diferem significativamente entre si pelo teste Tukey - $5 \%$.

* embrióides maduros = embribides completamente desenvol$\checkmark$ idos.

* embrioides nos estadios: globular, cordiforme, torpedo e cotiledonar. 
No presente trabalho, estudou-se o efeito de concentraçós relativamente altas de sacarose ( 30 a $50 \mathrm{~g} / 1$ ), verificando-se que a menor concentraça produziu melhores resultados que a major concentraça. Entretanto, um estudo ampliando a faixa de concentração de sacarose e de outros carboidratos seria interessante, pois segundo koCHBA et ali (1982), baixas concentraçZes de sacarose aumentaram a embriogenese em diferentes genotipos, inclusive, en cultivares de C. sinensis. Entretanto, por mais que estas concentraçoes de sacarose tivessem aumentado o número de embribides por calo, não conseguiram atingir os valores obtidos quando se utilizaramos carboidratos galactose e lactose.

o numero de embriódes, em estadio mais avancado de desenvolvimento (cotiledonar maduro), aumentou nos meios suplementados com sacarose. Este fato ocorreu, possiveimente, porque o numero total de embribides nestes meios foi menor e, havendo pouca concorrencia pelos nutrientes do meio de cultivo, os embrioides puderam utiliza-los com mais eficalia para promover o desenvolvimento.

KOCHBA et alii (1982) verificaram que a galactose e a lactose influenciaram positivamente o desenvolvimento dos embribides, favorecendo o desenvolvimento destes para formas cotiledonares mals avançadas, sendo que a lactose foi mais efetiva que a galactose.

No presente trabalno, observou-se que a Iactose produziu maior efeito no desenvolvimento dos em- 
brioides entre meios suplementados com galactose e lactose, porem, os meios contendo sacarose produziram os melhores resultados quanto ao número de embribides que alcancaram o estádio mais avançado de desenvolvimento, possivelmente, pela razáo ja citada acima.

\section{3. Desenvol vimento de plantas a partir de embribes somáticos em meios de cultura com diferentes concentraçóes de CIN e IAA (Experimento 4)}

Os embribides seguem um processo de maturação passando pelos estadios globular, cordiforme, torpedo e cotiledonar expandido ou embrião maduro (RANGASWAMY, 1961). Uma vez obtidos embriões somaticos maduros, a proxima fase de desenvolvimento, é sua conversão em plantas (SCHULTHEIS et alis, 1990).

A formação de ralzes e parte aerea, in vitro, e controlada pele relaça entre a concentraça de auxinas e citocininas presentes no meio de cultura.

KoCHBA et alii (1972) năobtiveram desenvolvimerto dos embribides em meio básico de cultura, porem, com a adiça de reguladores de crescimento tais como IAA, CIN OU GAs, este problema foi resolvido. Entretanto, outros autores nă tiveram dificuldade em regenerar plantas em meio basico de cultivo, sem a adiço de requladores de crescimEN To (NAVARRO \& JUAREZ, 1977 ; GOLDMAN, 1988 ). 
A Tabela 7 apresenta as observaçes realizadas, no presente estudo, sobre o desenvolvimento de embriódes inoculados en meios de cultura com diferentes concentraçסes de CIN e IAA, no estádio cordiforme $12-3 \mathrm{~mm}$ de comprimentol. Foram avaliadas as porcentagens de embrioides que desenvolveram ralzes, parte aerea e plantulas normais (parte aérea e raiz aparentemente normais). O desenvolvimento anormal foi observado em muitos embribides em todos os meios de cultura, e incluia anormalidades tais como cotiledones múltiplos, cotiledones fundidos e fasciados. A formaça de plantulas normais (Figura 10) foi prejudicada devido as anomalias encontradas nos embribides. Muitos embribides desenvolveram o sistema radicular, porém, os cotiledones apresentavam anormalidades (Figuras 11 a 13 ) e não se observou o desenvolvimento dos apices meristematicos deixando, entá, de formar a parte aerea da planta. Anormalidades foram tambem observadas nos apices meristematicos (Figura 14), desenvolvidos a partir dos embrioides germinados. Estas anormalidades ja foram relatadas em varios traDal Hos (RANGASWAMY, 1958; KOCHBA et alii, 1972; GMITTER \& MOORE, 1986; PASQUAL et alii, 1988).

Un trabalio semelhante a este foi realizado por GMITTER \& MOORE $(1986)$. Estes autores inocularam embribides cordiformes en meio de cultura e, quando estes atingiram o estadio desenvolvido (cotiledones e primordios de gemas e raszes), foram transferidos para meio suplementa- 
do com $1 \mathrm{mg} / \mathrm{l}$ de GAs para induzir a germinaça. No entanto, eles observaram que das varias centenas de embribides produzidos pela maioria dos eultivares estudados, poucas plantas foram obtidas. Foram observadas anormalidades entre os embrioides produzidos de todos os cultivares, em todos os meios estudados, incluindo pluricotiledonia, apices meristemáticos múltiplos, embriódes fundidos e fasciaça dos cotilédones. Para o cv. Hamlin (Citrus sinensis), somente $35 \%$ dos embribides pareciam suficientemente normais listo $b$, com alguma evidencia de polaridade e desenvolvimento cotiledonar) para garantir a transferencia para meio de germinaçå.

No presente trabalio năo se quantificou o número de embrioides que foram capazes de se desenvolver ate o estádio cotiledonar, assim como, o número de embribides que atingiram o estadio cotiledonar e, posteriormente, formaram plantas. No entanto, observou-se que de um total de plantas inotuladas no meio contendo $1,0 \mathrm{mg} / 1$ de CIN E $0,1 \mathrm{mg} / 1$ de IAA, por exemplo, 36,37\% dos embribides desenvolveram plantas normais. 
Tabela 7. Observaçbes sobre o desenvolvimento de embrioides* em meios de cultura com diferentes concentraços de CIN e IAA. Avaliação 8 semanas apos o inlcio do cultivo.

\begin{tabular}{|c|c|c|c|c|}
\hline $\begin{array}{c}\text { Tratamentos } \\
(m g / 1)\end{array}$ & $\begin{array}{l}\text { No de } \\
\text { embribides } \\
\text { ino- } \\
\text { culados }\end{array}$ & $\begin{array}{c}\text { Embrioi- } \\
\text { des pro- } \\
\text { zindo } \\
\text { ralzes } \\
(\%)\end{array}$ & $\begin{array}{c}\text { Embrioi- } \\
\text { des } \\
\text { produ- } \\
\text { zindo } \\
\text { p.aerea } \\
(\%)\end{array}$ & $\begin{array}{c}\text { Plantulas } \\
\text { normais } \\
(\%)\end{array}$ \\
\hline MT & 24 & 58,33 & 33,33 & 25,00 \\
\hline$M T+C I N-0,0+I A A-0,1$ & 18 & 55,55 & 22,22 & 11,11 \\
\hline$M T+C I N-0,0+I A A-0,5$ & 16 & 62,50 & 50,00 & 18,75 \\
\hline$M T+C I N-0, O+I A A-1,0$ & 13 & 69,23 & 46,16 & 15,38 \\
\hline$M T+C I N-0,1+I A A-0,0$ & 18 & 50,00 & 27,77 & 22,22 \\
\hline$M T+C I N-0,1+I A A-0,1$ & 19 & 42,10 & 36,84 & 26,31 \\
\hline$M T+C I N-0,1+I A A-0,5$ & 21 & 52,38 & 28,57 & 19,04 \\
\hline$M T+C I N-0,1+I A A-1,0$ & 19 & 57,89 & 42,10 & 21,05 \\
\hline$M T+C I N-0,5+I A A-0,0$ & 22 & 57,27 & 27,27 & 4,54 \\
\hline$M T+C I N-0,5+I A A-0,1$ & 20 & 55,00 & 15,00 & 10,00 \\
\hline$M T+C I N-0,5+I A A-0,5$ & 21 & 57,14 & 42,85 & 21,85 \\
\hline$M T+C I N-0,5+I A A-1,0$ & 14 & 71,42 & 35,71 & 21,42 \\
\hline$M T+C I N-1, O+I A A-0,0$ & 20 & 55,00 & 20,00 & 10,00 \\
\hline$M T+C I N-1, O+I A A-0,1$ & 22 & 50,00 & 45,45 & 36,37 \\
\hline$M T+C I N-1, O+\operatorname{IAA}-0,5$ & 20 & 55,00 & 25,00 & 15,00 \\
\hline$M T+C I N-1, O+I A A-1,0$ & 16 & 43,75 & 31,25 & 12,50 \\
\hline
\end{tabular}


Quanto ao efeito dos reguladores CIN e IAA no desenvolvimento dos embribides, os resultados apresentados na Tabela 7 mostraram que, no presente estudo, a porcentagen de formaço de raiz ná foi muito diferente para os meios utilizados, exceto para os meios contendo a maior concentraça de IAA $(1,0 \mathrm{mg} / 1)$ e as mais baixas concentraços de CIN. Este resultado esta de acordo com o que foi observado por KOCHBA et elil (1972). Segundo estes mesmos autores, tanto 0 GA3 e O IAA estimularam o enraizamento nos embrioides do ev. shamouti (C. sinensis), enquanto os embrioides do ev. Valencia enrelzaram melhor com a adiçá de GAs e o cv. Marsh, com a adição de IAA.

Una interaça entre sacarose e requladores de crescimento foi encontrada no enraizamento de embribes somaticos of Citrus sinensis cv. Shamouti. O enraizamento foi otimo com $5 \%$ e $6 \%$ de sacarose, quando o sulfato de adenina (ADS) e O GA3 foram adicionados ao meio. No entanto, o enraizamento, na ausencia de ADS ou GA3, ocorreu numa faixa mais ampla de concentraçßes $(2$ a $6 \%$ ) de sacarose (KOCHBA et alis, 1974$)$.

Os resultados apresentados na Tabela 7 , mostraram que as altas concentraçós de IAA tambem favoreceram - desenvolvimento da parte aerea nos embrioides; no entanto, observa-se que o meio contendo $\operatorname{CIN}(1,0 \mathrm{mg} / 1)$ e IAA $(0,1$ mg/1) tambem favoreceu o desenvolvimento da parte aerea e, ainda, deu origem a maior porcentagem de plantas normais 
$(36,37 \%)$. En sua pesquisa, KOCHBA et alii (1972) verificaram que altos nlveis de CIN e baixos de IAA foram melhores que outras taxas de CIN/IAA para o desenvolvimento de ambos os brgaos.

No presente trabalho, os embribides foram inoculados em meio de cultura no estadio cordiforme aproximadamente $2-3 \mathrm{~mm}$ de comprimento. 0 estadio de desenvolvimento dos embribides tem grande influencia sobre a germinaçăo destes embrioides e regeneraçáo de plantas. KochBA et alii ( 1974 ) observaram que embribides com cotiledones ja desenvolvidos tiveram uma porcentagem de enraizamento de $83 \%$ em meio basico, enquanto que em embribides inoculados no estagio cordiforme ( $3-5 \mathrm{~mm}$ de comprimento) observou-se uma porcentagem de $38 \%$ de enraizamento em meio basico. Neste último caso, a adição de GA3, ao meio basico de cultivo, elevou a porcentagen para $67 \%$ de enraizamento. Portanto, se os embrioides utilizados estivessem em um estádio mais avancado de desenvolvimento, e possivel que, malores porcentagens de plantas normais tivessen sido obtidas.

Apesar de grande porcentagem de anormalidades encontradas nos embrioides, estudos demonstraram que as plantas, obtidas, a partir da regeneraça de embrioides obtidos em nucelos, calos embriogenicos e protoplastos, eram normais (NAVARRO et alii, 1979; VARDI et alii, 1982; $\mathrm{kO}-$ BAYASHI et alii, 1984, KOBAYASHI, 1987). 
Segundo KOBAYASHI (1987) a explicaço para a estabilidade fenotipica encontrada nos protoclones (clones regenerados de protoplastos obtidos a partir de calo embriogenico, pode estar na forma de regeneracăo destas plantas, ou seja, vía embriogenese somatica. VASIL (1983) relatou que a estabilidade genetica encontrada en plantas regeneradas a partir de calos tecidos de muitas especies de gramineas era devido a regeneraço atraves da embriogenese somatica.

Este fato indica o grande potencial da aplicação prática de calos nucelares embriogenicos em programas de melhoramento de citros.

4. 4. Efeito de diferentes meios de cultura no desenvolvimento dos calos nucelares e induça da embriogenese nestes calos (Experimento 5 )

Calos obtidos de acordo com o procedimento descrito no item 3.2 .5 foram inoculados en diferentes meios de crescimento. Os resultados apresentados na Tabela 8 representam o peso médio destes calos e o número medio de embribes obtidos a partir destes nos diferentes meios de cultura estudados.

Observa-se que o meio de cultura MT, suplementado com galactose foi o que apresentou maior peso médio 
de calo. Entretanto, devido impossibilidade de separar calos e enbrioides, os valores modios para peso representam - peso total de calos e embribides formados. Assin sendo, natural que grande parte do valor apresentado para o peso medio seja devido a presença de embrioides e nzo propriamente a proliferaço de calos, neste meio de cultura. Este fato tamben se aplica a meio de cultura MT suplementado com lactose. Por outro lado, e posslvel que, os embrioides, competindo por nutrientes do melo de cultura, ná permitam maior desenvolvimento dos calos nos meios com galactose e lactose.

Levando estes fatos em consideraçăo, pode-se notar que o meio de eultivo, suplementado com CIN (1,0 mg/l) e IAA $(0,1 \mathrm{mg} / 1)$, apresenta un valor que nao difere significativamente do major valor encontrado para o peso e também apresenta um pequeno número de embribides por calo, podenoose, entzo, concluir que este mejo de culture favoreceu a proliferaça de calos nucelares.

Os melos de cultivo suplementados com lactose e galattose promoveram significativamente a embriogenese nos calos nucelares. 
Tabela 8. Peso madio dos calos e numero modio de enbríbides por calo cultivado en meio basico MT con diferentes suplemen t eçes. Avaliaça 40 dies aps infeio do cultivo.

Tratamentos

(ng/1)
Peso medio dos

calos (mg)
N- medio de

embribides/calo
Lactose-50.000

Galactose -50.000

$E M-500$

CIN-O,O+IAA-0,O

CIN-O,O+IAA-0, 1

CIN-O,O+IAA-0, 5

CIN-O,O+IAA-1,O

CIN-O, I IAA-O,O

CIN-O,1+IAA-0,1

CIN-O,1+IAA-0,5

$C I N-0,1+I A A-1,0$

CIN-O, S+ IAA-O,O

CIN-O, S+IAA-O, 1

CIN-0,5+IAA-0,5

$\operatorname{CIN}-0,5-1 A A-1,0$

CIN-I,O+1AA-O,O

EIN-1,O+IAA-O,1

CIN-1,O-1AA-0,5

CIN-1,O+IAA-1,0

$B A P-10,0$
$126,79 \mathrm{ab}$

$201,93 a$

$71,88 b$

$69,69 \mathrm{~b}$

$89,95 \mathrm{~b}$

$115,20 \mathrm{ab}$

$89,95 \mathrm{~b}$

128,94 ab

$101,42 b$

$97,82 \mathrm{~b}$

$95,32 \mathrm{~b}$

$99,83 \mathrm{~b}$

$85,56 \mathrm{~b}$

$89,54 \mathrm{~b}$

$67,96 \mathrm{~b}$

157,14 ab

155,74 ab

119,73 ab

$93,74 b$

$85,51 b$
540,05 a

$207,11 \mathrm{~b}$

$25,43=$

$19,94 \mathrm{C}$

$14,65 \mathrm{C}$

$18,86 \mathrm{C}$

$6,84 c$

$28,03 c$

$10,89 \mathrm{C}$

$12,11 \mathrm{C}$

$9,18 \mathrm{C}$

$15,25 \mathrm{C}$

$12,31 \mathrm{c}$

$10,89 \mathrm{C}$

$8,17 \mathrm{C}$

$37,77 \mathrm{c}$

$7,83=$

$25,74 c$

$12,82 \mathrm{c}$

$0,58 \mathrm{C}$

Medias seguidas de letras iquais nă diferem significativamente entre si pelo teste de Tukey $-5 \%$. 
Embora os valores obtidos par o numero nodio de embribides por calo nao estejam diferindo significativamente entre 1 , pode-se observar que, de forma geral, ha uma tendancia do numero de embrióldes diminuir com o aumento da concentraça de IAA, nos tratamentos combinando as diferentes concentraçes de CIN e IAA. O tratamento que resultou no maior número de embrióldes diferenciados por calo foi aquele en que se adicionou $1 \mathrm{mg} / 1$ de CIN ao meio MT.

- meio contendo BAP $(10 \mathrm{mg} / 1)$ resultou no menor número de embriolides obtidos e o meio contendo EM $(500$ mg/1) não estimulou a embriogenese; estes fatos estao de acordo com o que fol observado por KOBAYASHI et ali $(1984)$.

De acordo com os trabalhos realizados por KOCHEA E SPIEGEL-ROY (19770) e KOCHBA et al1I (1982), substancias que inibem a sintese de auxinas e citocininas estimularam a embriogenese em calos nucelares habituados do CV. Shemouts (C. SIMENSIS). SEgundo KOCHBA \& SPIEGEL-ROY (1977b), a presença de IAA, no mejo de cultura, suprinilu a embriogenese en concentraços acima de $1,0 \mathrm{mg} / 1$. A presença de CIN não suprimiu a embriogenese em nenhuma das concentraços utilizadas, porem, causou uma diminuiço no número de emorides obtidos em relaçăo ao meio básico.

No presente estudo, observou-se que as diferentes concentraçBes de IAA diminuiram a embriogenese, porem, na houve supressão da mesma em nentuma concentraçăo; veri- 
ficou-se tamben que a CIN promoveu um aumento na embriogenese nas concentracbes de 0,1 e $1,0 \mathrm{mg} / 1$. Curiosamente, neste trabalho, a maior concentracto de $\operatorname{CIN}(1,0$ mg/1) utilizada tamben foi melhor para induzir a embriogonese a partir de nucelos. Possivelmente, concentracbes maiores de cinetina sejan necessarias, no cv. Pera, para induzir a embriogenese.

A cinetina tamben promoveu um aumento no peso dos calos nas maiores concentraçbes, o que esta de acordo com os resultados obtidos por KOCHBA \& SPIEGEL-ROY $(1977 \mathrm{~b})$

- erescimento dos calos, de forma geral, oiminuil com o aumento da concentração de IAA, porem, deve-se considerar que o numero de embrioides tambem diminuiu nestes casos e isto pode estar influenciando nos valores encontradOs para o pESO. KOCHBA SPIEGEL-ROY (1977b) observaram que o crescimento dos calos na presenca de IAA fol, geralmerte, menor que na ausencia desta substancia, mas a resposta ao aumento oas concentraçoes de IAA flutuaran, cons oeraveimente. 


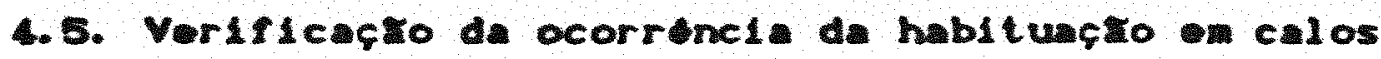 - mbr 1 ogenicos (Experimento b)}

Os resultados apresentados na Tabela 9 permiten concluir que os calos nucelares do cv. Pera, apos quatro subcultivos en meio basico MT, continuaram a proliferar mesmo sem a adiço de reguladores de crescimento ao meio basico de cultivo. Este fato indica que os calos nucelares perderam a necessidade de fornecimento de citocininas e auxinas ao meio basico de cultura para proliferaçao. Este fenomeno e denominado de habituação.

observando-se os resultados apresentados na Tabela 9, pode-se notar que os meios suplementados com 0,1 mg/l de CIN e $0,5 \mathrm{mg} / \mathrm{I}$ de IAA, $0,5 \mathrm{mg} / 1$ de CIN e $0,5 \mathrm{mg} / 1$ de IAA, e $1,0 \mathrm{mg} / 1$ de CIN e $0,1 \mathrm{mg} / 1$ de IAA e $10 \mathrm{mg} / 1$ de $\mathrm{BAP}$ tiveran un aumento da proliferaçăo en mejo básico MT, o que significa que nestes meios obteve-se o efeito da hatituaçă dos calos. Os mejos suplementados con $0,5 \mathrm{mg} / \mathrm{l}$ dE CIN E $0,5 \mathrm{mg} / \mathrm{d}$ dE IAA E $0,5 \mathrm{mg} / 1$ de CINE $1,0 \mathrm{mg} / \mathrm{l}$ de IAA na promoveram a habituaçá dos calos nutelares.

A habituaça fol observade en vários trabaIhos com cultivo de calos em Citrus (SPIEGEL-ROY \& KOCHBA, 1975; HIDAKA \& KAJIURA, 1988). Os calos habituados continuaram a proliferar em meio sem reguladores de crescimento por vários anos (SPIEGEL-ROY \& VARDI, 1984). 
Tabela 9. Crescimento de calos nucelares en meios de cultura com en ediça de reguladores de crescimento eo meio de cultura basico - MT. Avaliafro realizada 45 dias apos o infcio do cultivo.

\begin{tabular}{|c|c|c|c|}
\hline $\begin{array}{c}\text { Adicbes ao meio } \\
\text { MT (mg/l) }\end{array}$ & $\begin{array}{l}\text { Peso medio } \\
\text { ne presença } \\
\text { de adiçbes } \\
\text { (A) }\end{array}$ & $\begin{array}{l}\text { Peso medio } \\
\text { na eusencia } \\
\text { de adiçes } \\
\text { (B) }\end{array}$ & $\begin{array}{c}\text { Taxa de } \\
\text { crescinento } \\
\text { B/A }\end{array}$ \\
\hline $\operatorname{CIN}-1,0+$ IAA-0,1 & $119,02 \mathrm{a}$ & $194,63 a$ & 1,63 \\
\hline$C I N-0,1+I A A-0,5$ & $71,93 a$ & $116,49 \mathrm{ab}$ & 1,62 \\
\hline$C I N-0,5+I A A-0,1$ & $87,18 \mathrm{a}$ & $107,89 b$ & 1,23 \\
\hline$B A P-10,0$ & 75,120 & $79,24 \mathrm{bc}$ & 1,05 \\
\hline$C I N-0,5+I A A-1,0$ & $80,47 a$ & $76,00 b c$ & 0,94 \\
\hline CIN-0,5+IAA-0,5 & $70,05 a$ & $53,18 c$ & $0,75 *$ \\
\hline
\end{tabular}

* Meios de cultura onde não ocorreu a habitueção.

Medias seguidas de letras iguais nao diferem significativamente entre si pelo teste de Tukey - $5 \%$.

SPIEGEL-ROY \& KOCHBA (1975) verificaram quE a major concentração de cinetina $(1 \mathrm{mg} / \mathrm{l})$ mostrou un maior efeito na habituação de calos, exceto quando a cinetina estava combinada com adenina. No presente trabalto, verificou-se que as concentraçoes de $1 \mathrm{mg} / 1$ de CIN em combinaçáo com $0,1 \mathrm{mg} / 1$ de IAA e $0,1 \mathrm{mg} / 1$ de CIN e $0,5 \mathrm{mg} / \mathrm{J}$ de IAA produziram o maior efeito na habituaça, pois os calos 
provenientes destes meios de cultur a apresentaram a maior taxa de crescimento em meio de cultivo, sem suplementacro com reguladores de crescimento.

A habituaça - considerada uma variação epigenetica associada com a cultura de tecidos de plantas in VITEO (SKIRUIN, 1978).

Calos nucelares embriogenicos habituados tem sido utilizados, com grande sucesso, na obtenção de protoplastos totipotentes. Segundo GROSSER \& GMITTER (1990), calos que necessitam de reguladores de crescimento, isto e, calos náo habituados, nao sáo capazes de ressintetizar a parede celular e entrar en oivisão nos meios de cultura estabelecidos para cultivo de protoplastos de citros, meios estes que, en sua grande maioria, ná incluem os requladores de crescimento. Porem, quando protoplastos provenientes de calos nao habituados 5 ao fundidos com protoplastos de calos habituados, ocorre a complementaça e, portanto, E restaurada a capacidade de regeneraça de plantas a partir oos protoplastos fundidos. Da1, provavelmente, a importancia de se obter calos habituados. 


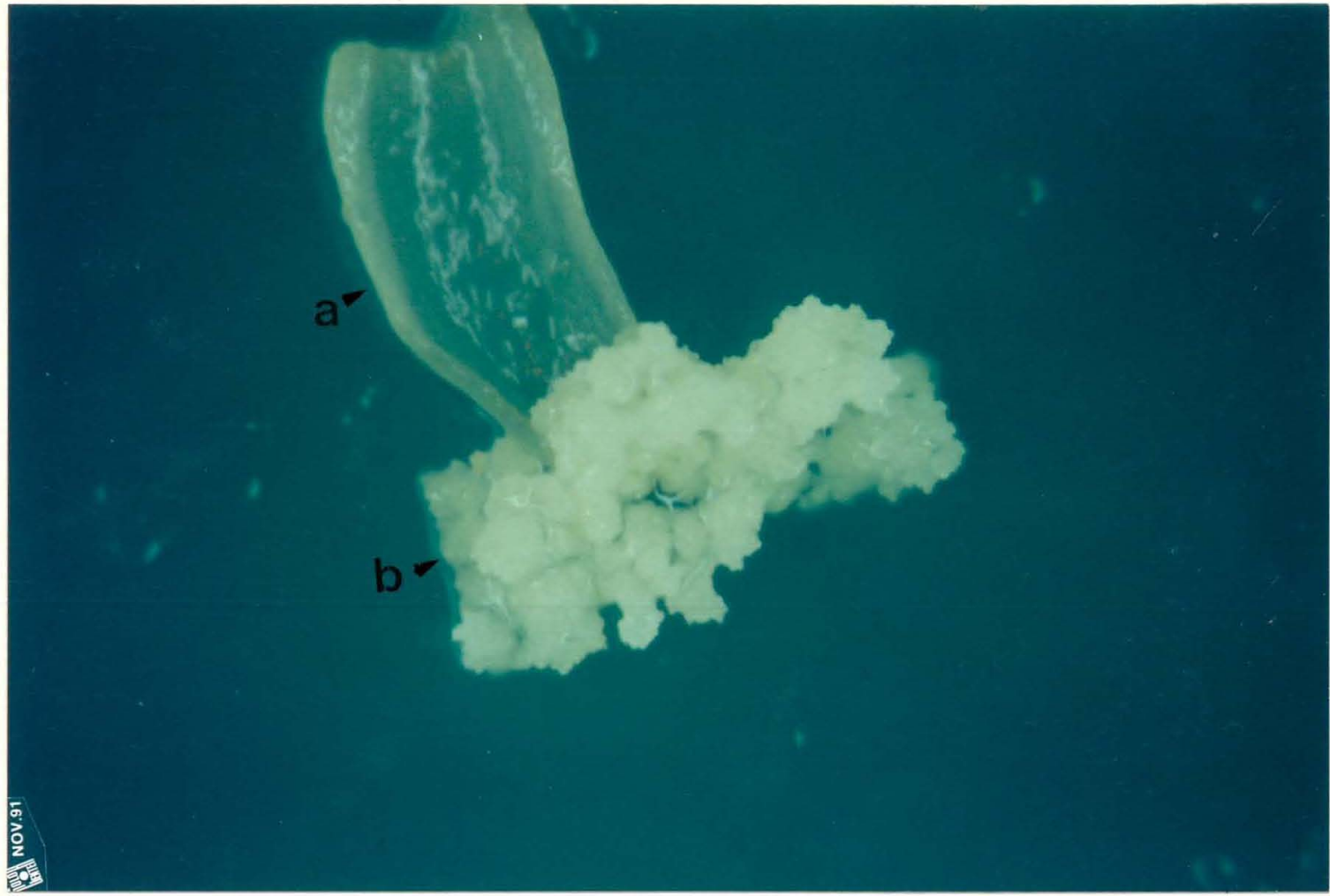

Figura 2. Proliferação de calo em nucelo, em meio de cultura suplementado com $10 \mathrm{mg} / \mathrm{l}$ de BAP.

(a) nucelo; (b) calo nucelar $(\times 10)$.

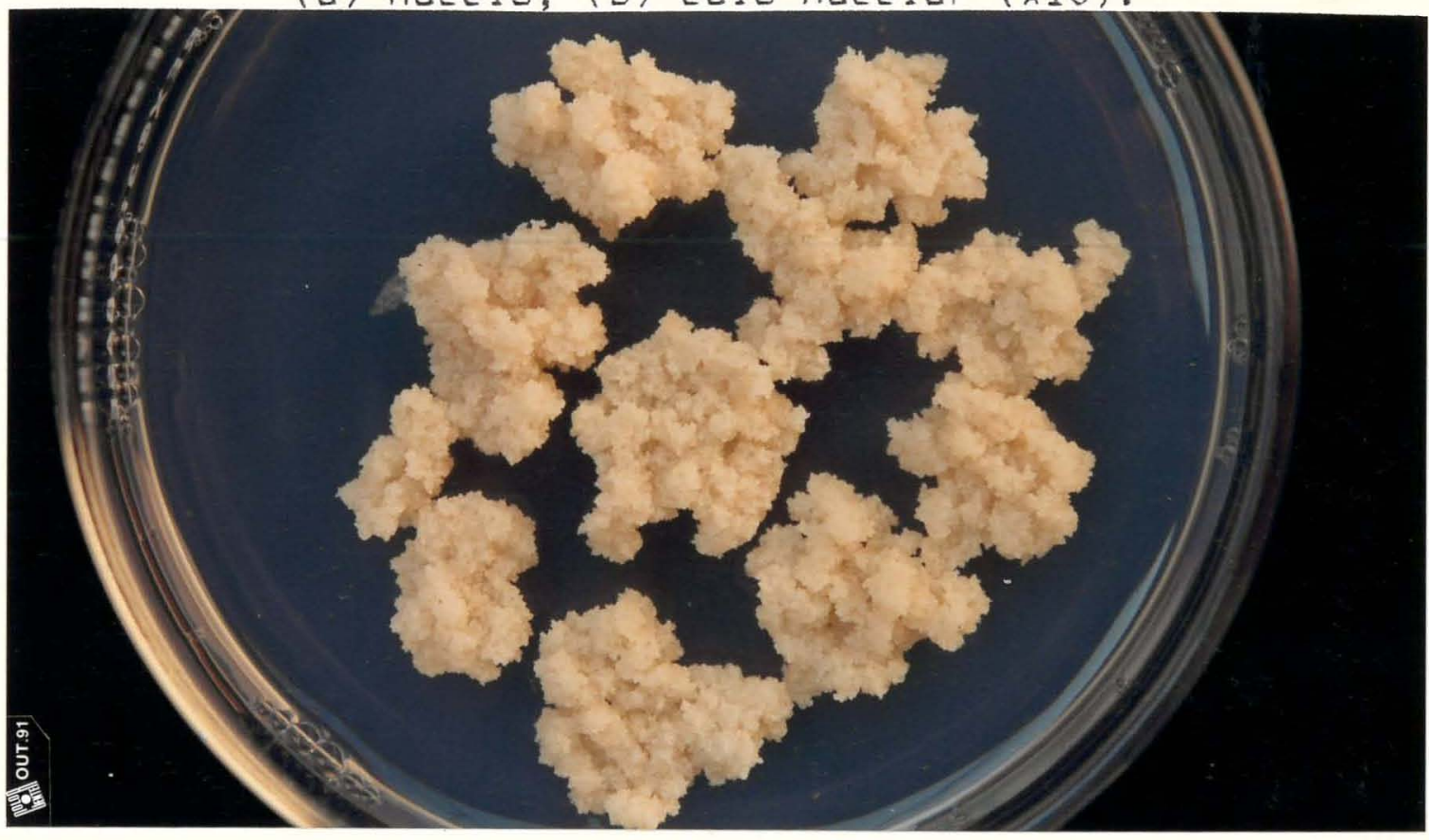

Figura 3. Proliferaçăo de calos embriogénicos em meio suplementado com $10 \mathrm{mg} / \mathrm{l}$ de BAF. 


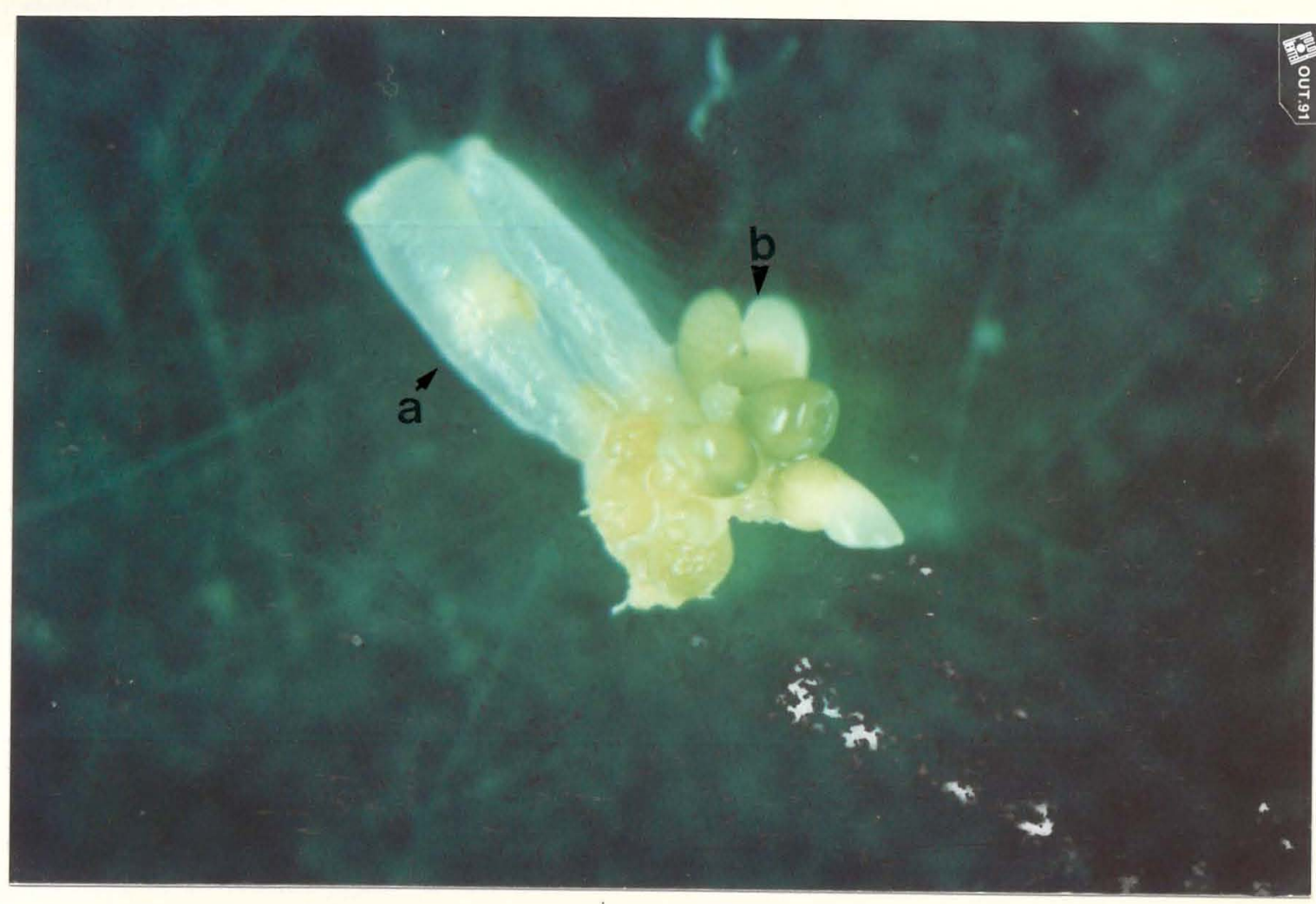

Figura 4. Proliferaçăo de embrióides

(b) em nucelos

(a) $(\times 10)$.

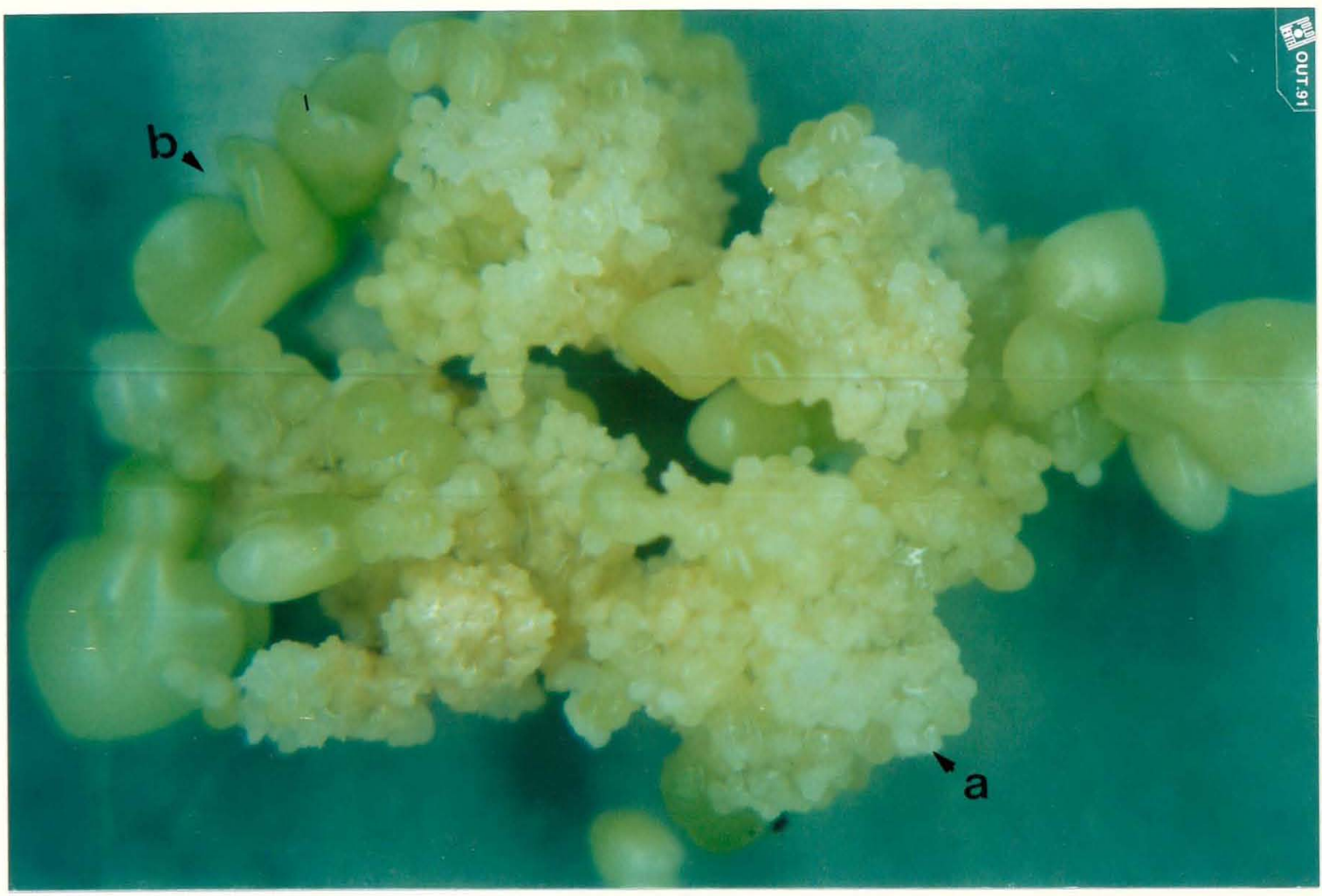
Figura 5. Proliferaçă de embrióides (b) em calos nucela-
res (a) $(\times 10)$. 


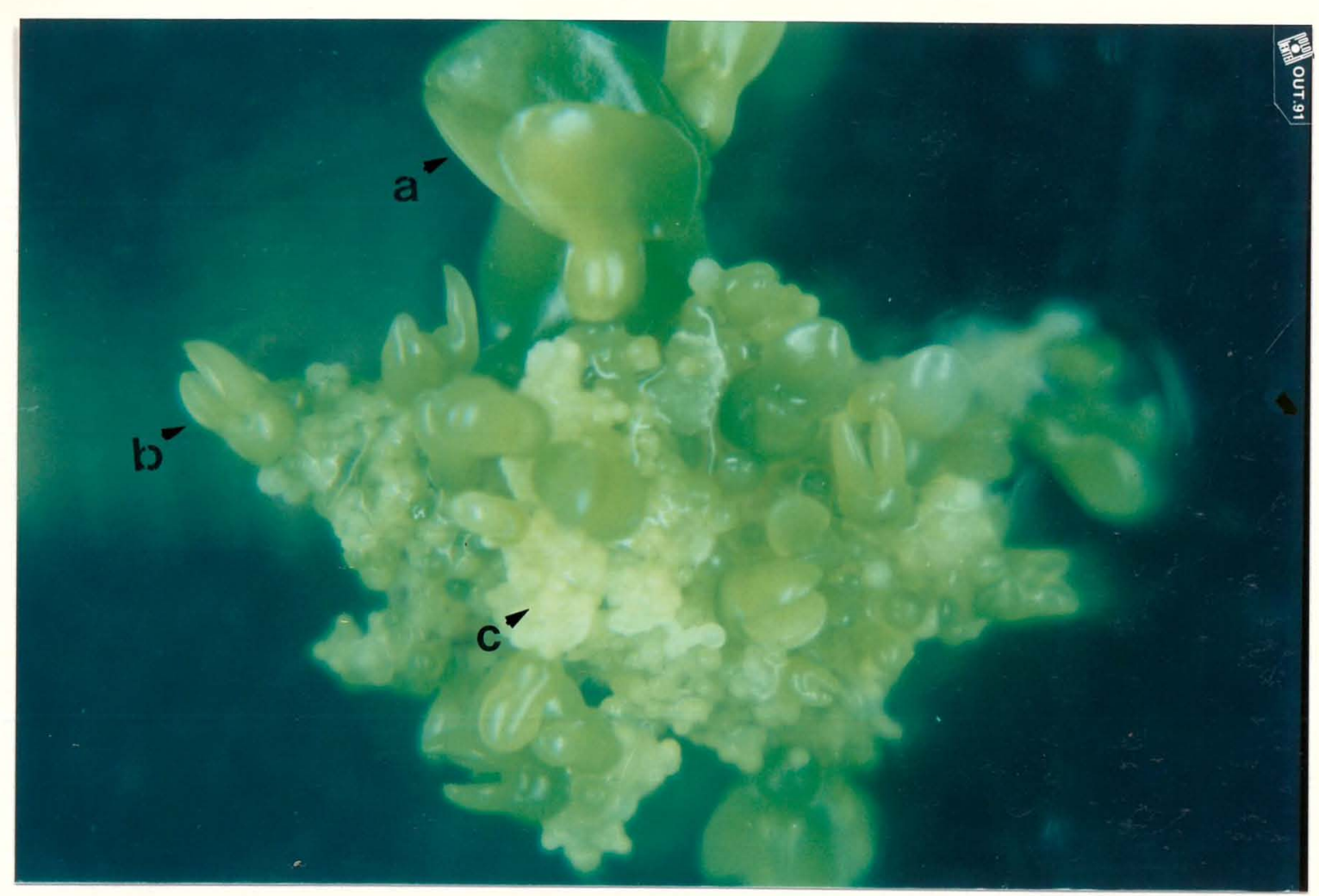

Figura 6. Embribides normais e maduros (a) e embrioides cotiledonares normais e imaturos (b) obtidos em calos nucelares (c) cultivados em meio suplementado com $50 \mathrm{~g} / \mathrm{l}$ de lactose e $500 \mathrm{mg} / \mathrm{l}$ de EM, 40 dias após o cultivo $(\times 10)$.

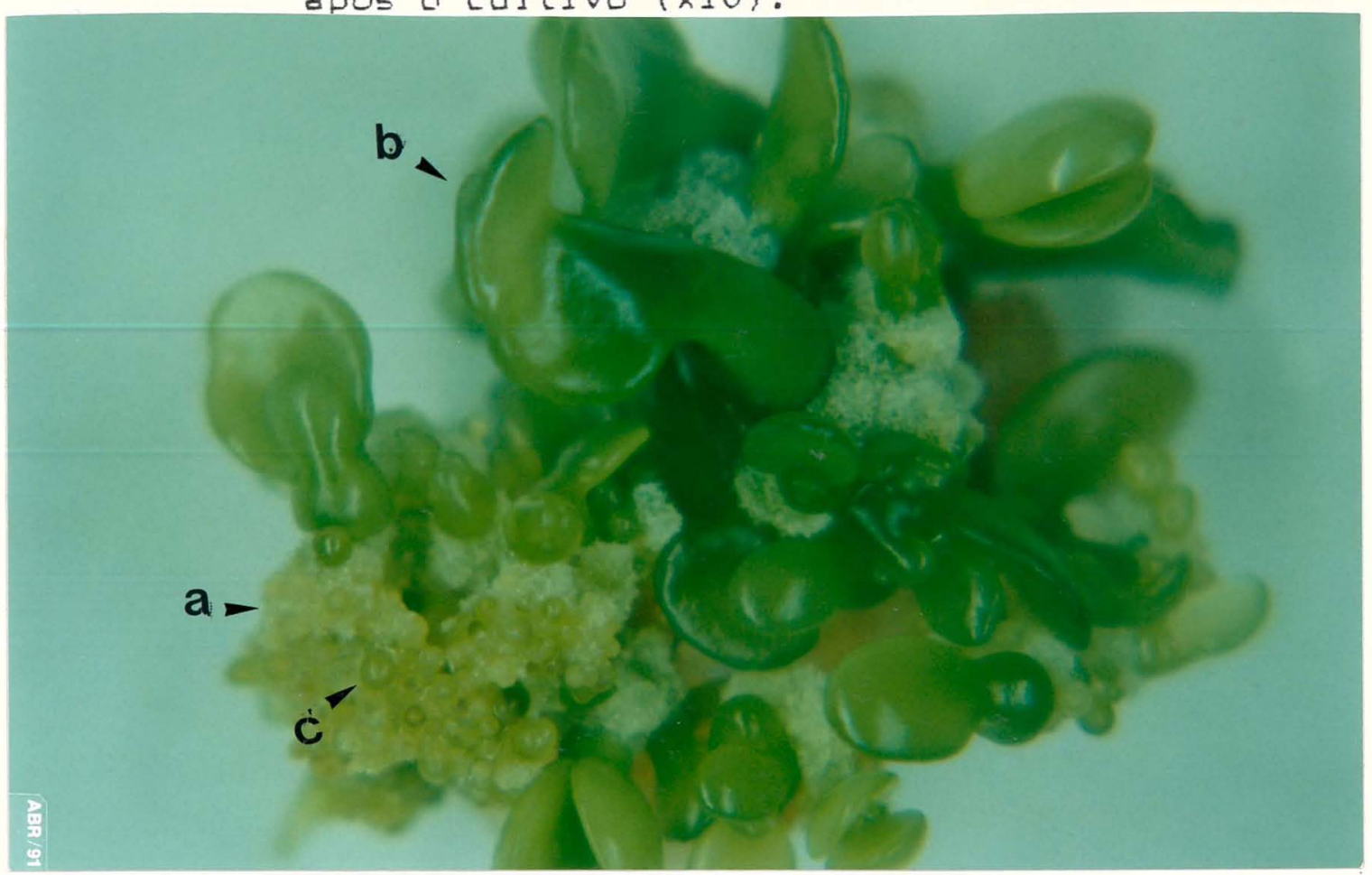

Figura 7. Calo embriogenico (a) apresentando embrióides cotiledonares maduros (b) e embribides no estádio globular (c) após 60 dias de cultivo em meio com $50 \mathrm{~g} / \mathrm{l}$ de lactose e $500 \mathrm{mg} / \mathrm{l}$ de EM $(\times 10)$. 


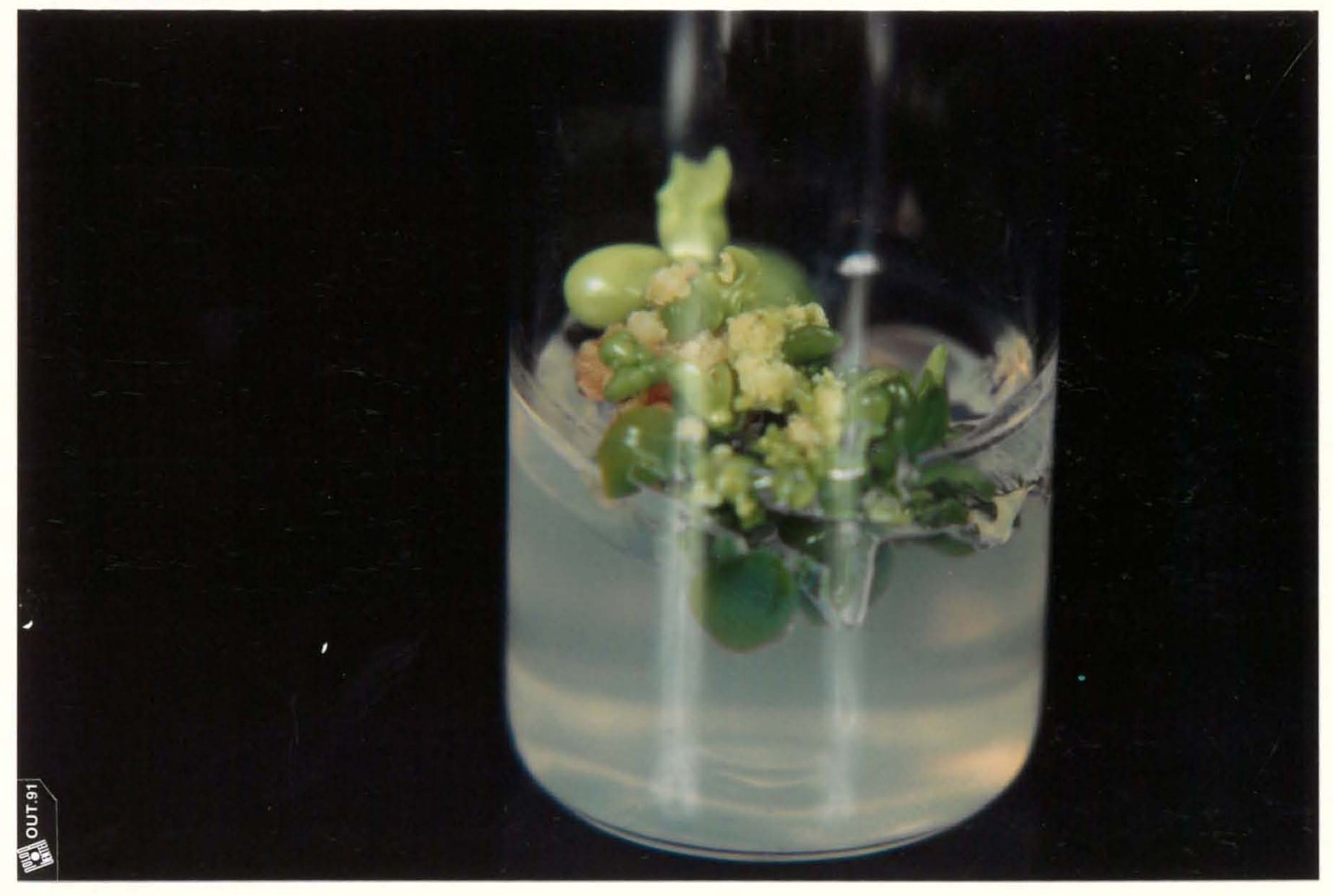

Figura E. Formação de embriódes em calos embriogénicos. 


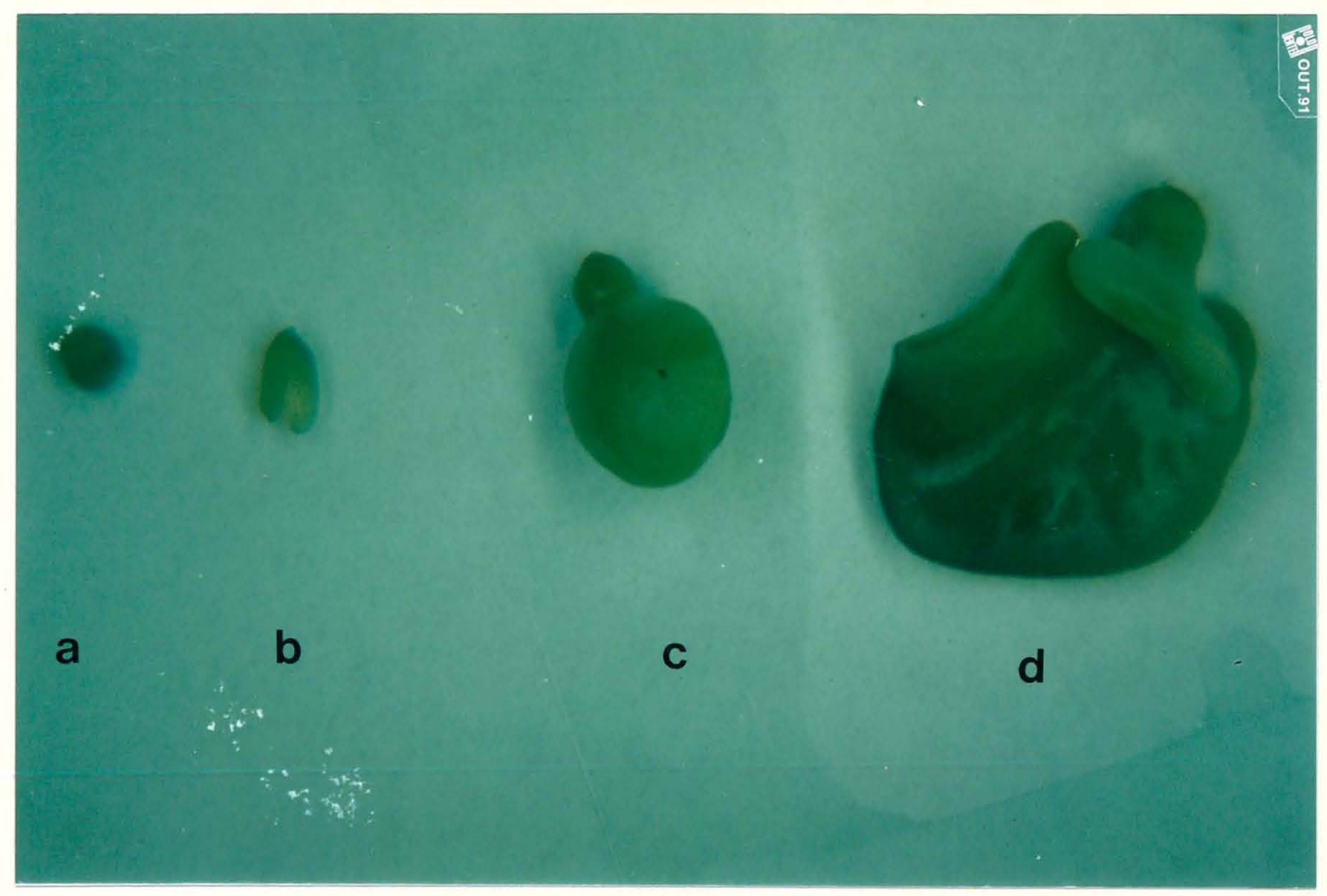
Figria 9. Embridides de Citrus sinensis cv. Pera em pro- cesso de maturação. Os diferentes estádios de de- senvolvimento podem ser observados em calos nuce- lares inoculados em meio suplementado com lactose e EM. (a) embrióide globular; (b) embribide com cotilédones em formação; (c) e (d) embriobides com dois cotiledones proeminentes $(\times 10)$.




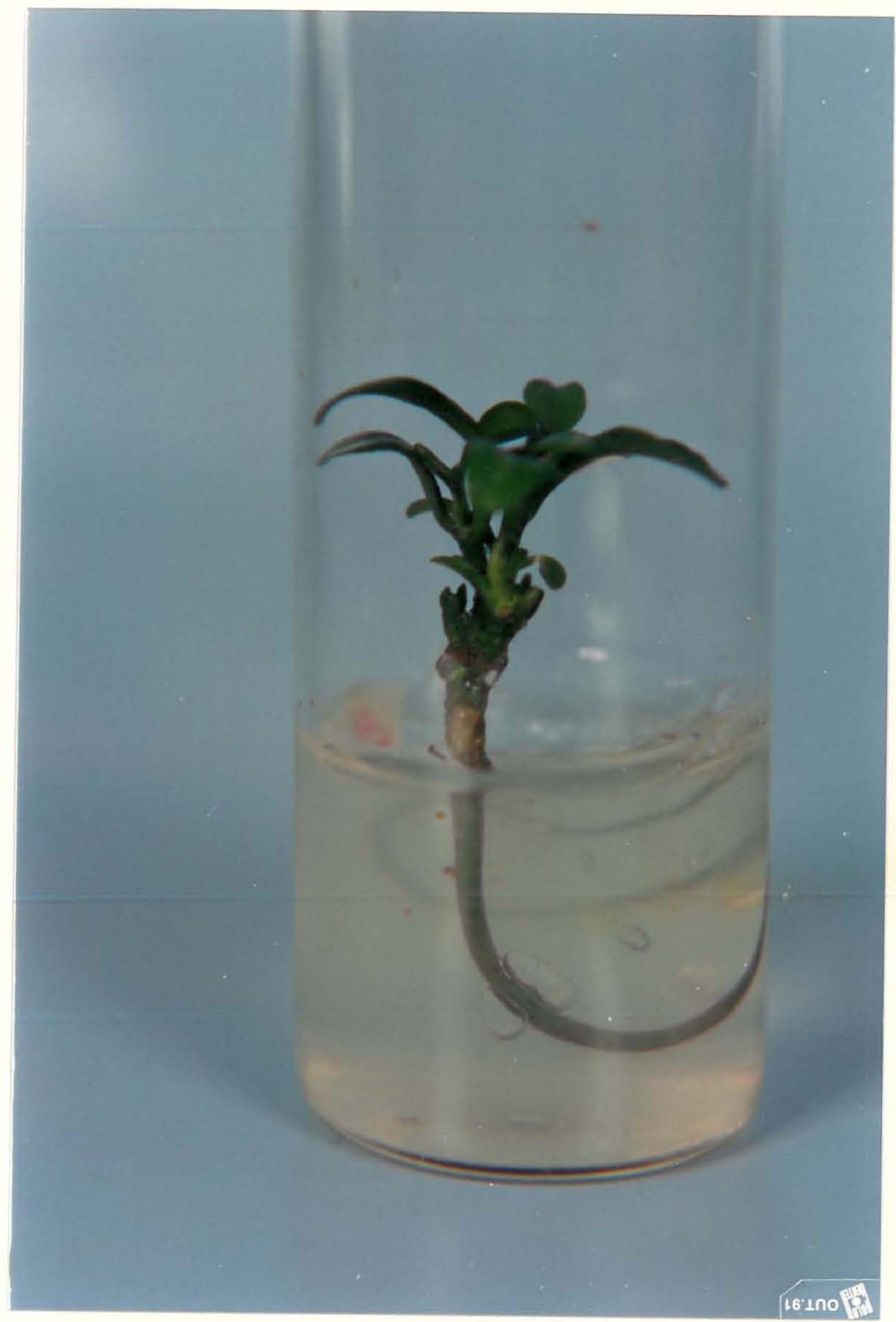

Figura 10. Plántula regenerada via embriogénese somática partir de calos nucelares, apresentando raiz parte aérea normais. 


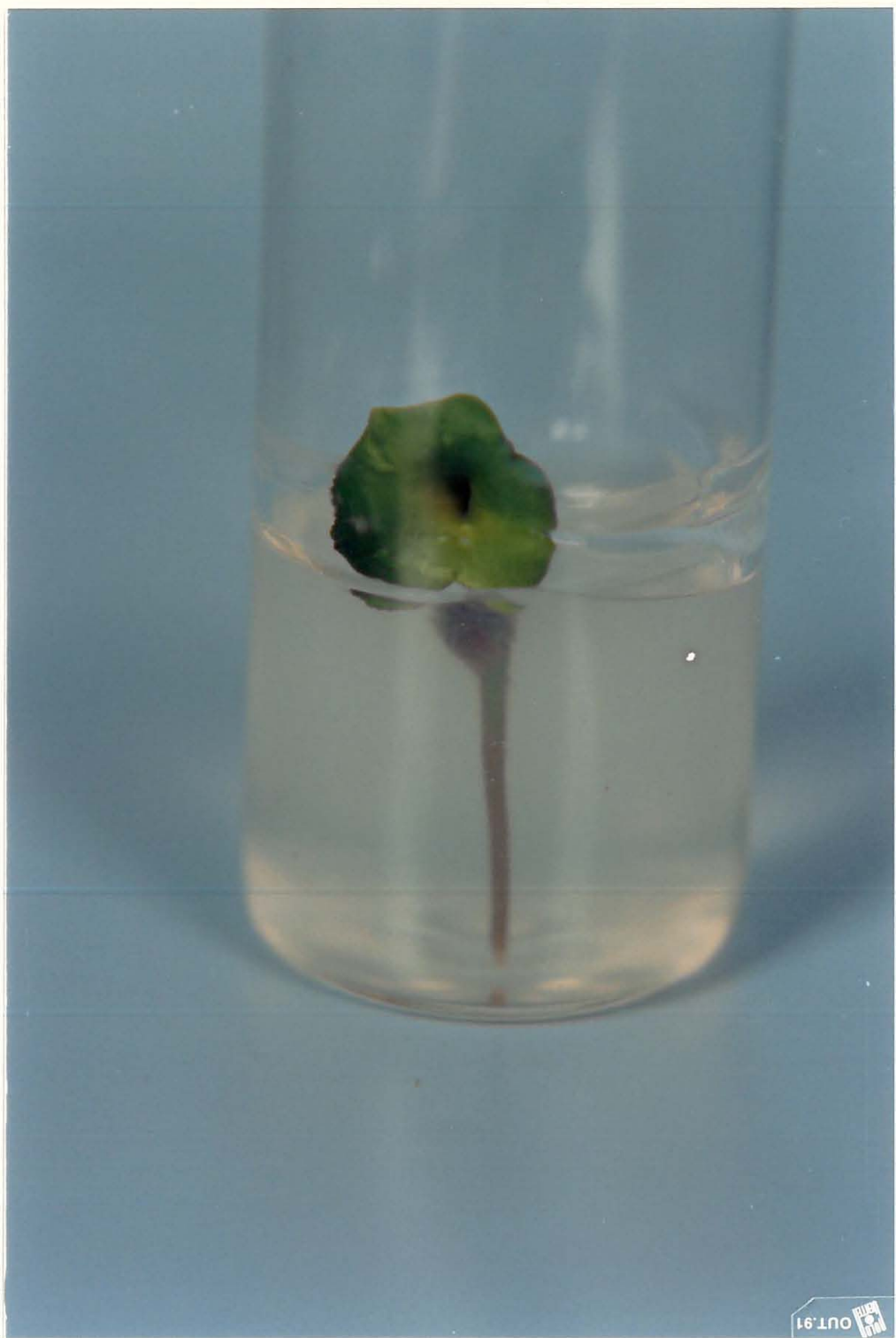

Figura 11. Plántula anormal com raiz e apresentando coti-. dones fundidos, semelhante a uma corneta. 


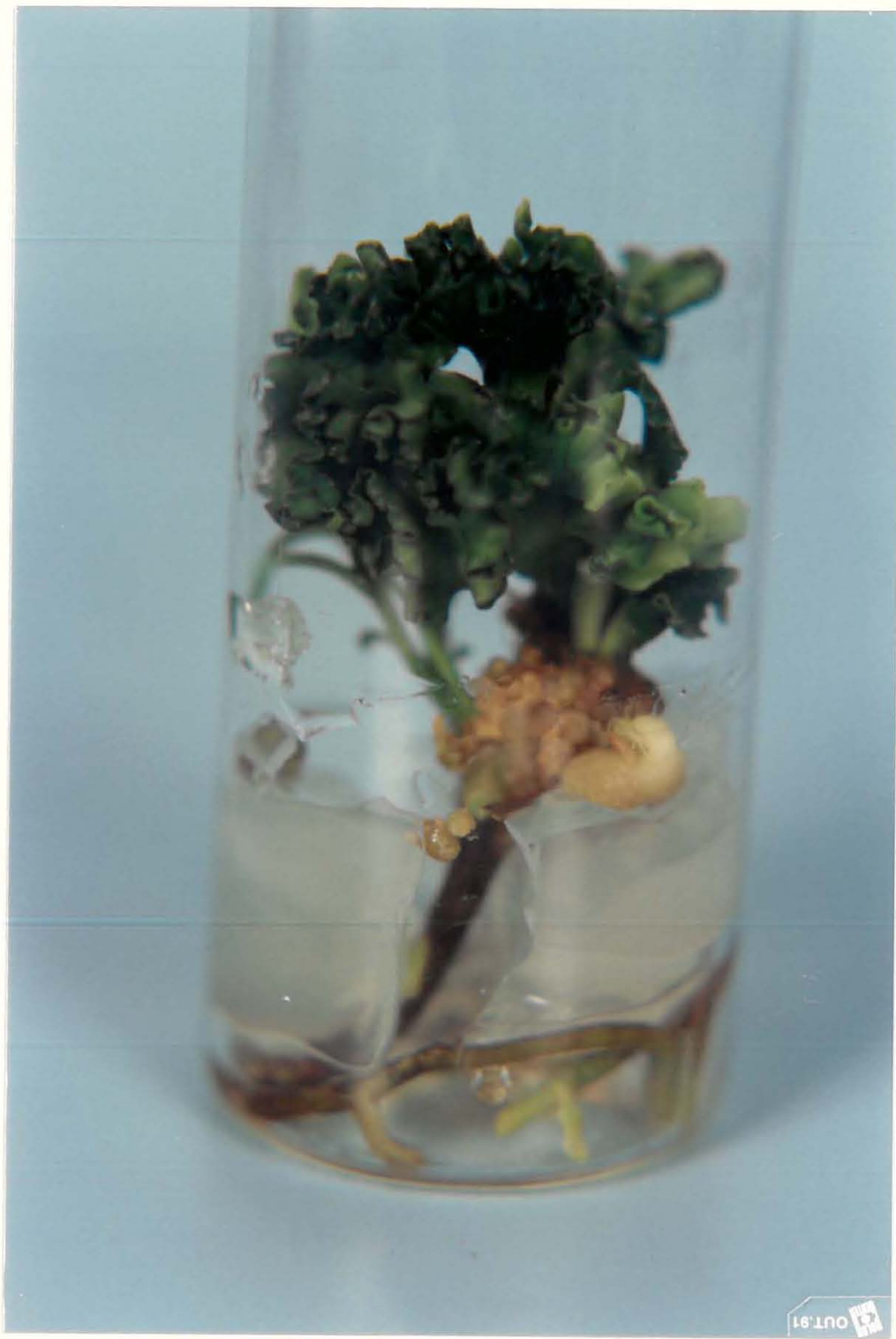

Figura 12. Plántula em roseta apresentando raiz e formação de cotilédones fasciados. 


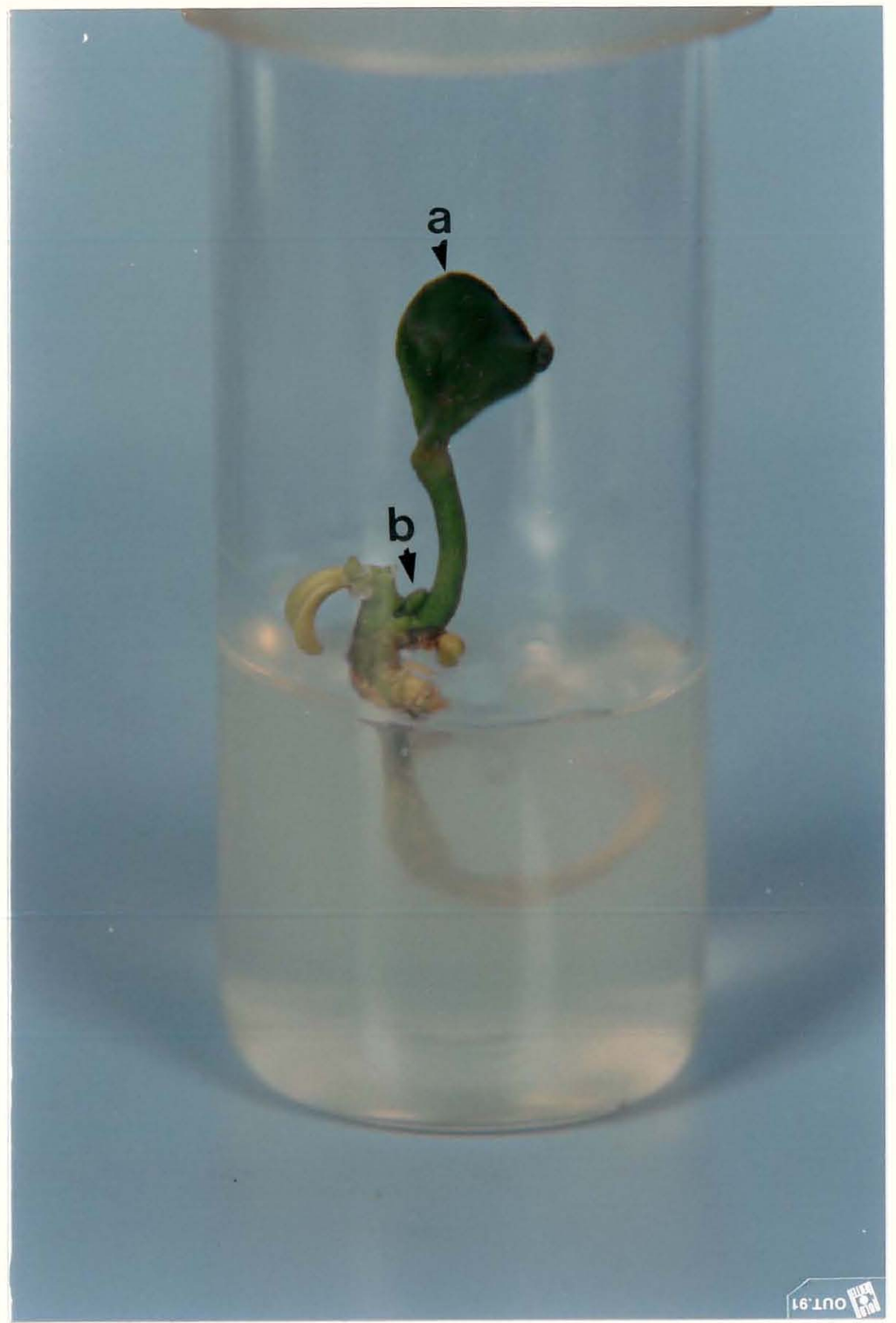

Figura 13. Plántula anormal enraizada apresentando um único cotilédone (a) e a presença de um meristema apical rudimentar (b). 


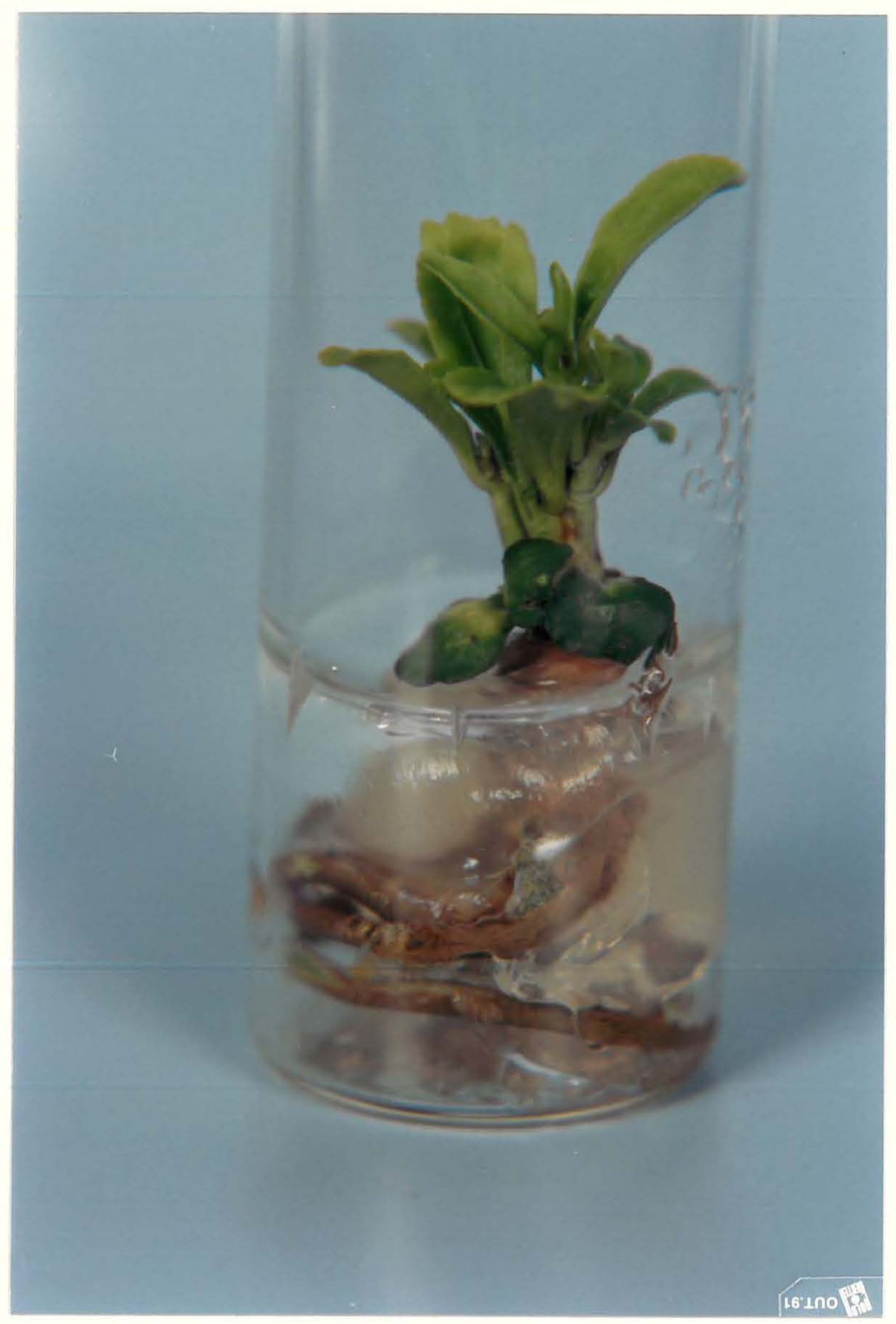

Figura 14. Plántula apresentando desenvolvimento da parte aérea anormal (gemas apicais múltiplas) e raiz. 


\section{6. Induço de brotaçes adventselas (Experimento 7 )}

Os cotiledones de embrioides nucelares (figura 15) foram escolnidos como explantes, neste experimento, pois sao os primeiros orgaos a se formarem no embrioide maduro e devido ao seu potencial inerente para regeneraça de orgãos adventIcios (BURGER \& HACKETT, 1982).

Nos diferentes protocolos estabelecidos para a induço de gemas adventicias,por via direta ou indireta, o meio de cultivo constituia-se do meio MS (MURASHIGE \& SKOOG, 1962) suplementado com $50 \mathrm{~g} / 1 \mathrm{de}$ sacarose, $500 \mathrm{mg} / \mathrm{l}$ de EM e o balanço de concentraça de dols reguladores de erescimento, invariavelmente, $B A$ E NAA.

A Tabela 10 apresenta as porcentagens medias de formação de brotaçós adventicias e o numero medio de brotaços obtidas por explante responsivo, 90 dias apos o inicio do cultivo dos explantes. Observa-se que as porcentagens de explantes que responderam aos tratamentos variam de 0 a $44,45 \%$. A maior meda de brotaçes por explante foi encontrada para o meio de cultura suplenentado com 0,5 mg/i de BAF E $1,0 \mathrm{mg} / 1$ OE NAA.

No presente estudo, utilizou-se o meio basico MT suplementado con $30 \mathrm{~g} / \mathrm{l}$ de sacarose, e diferentes combinaçbes de concentraçBes iguais de BAP e NAA, enquanto, na maioria dos protocolos estas combinaços eram feitas com concentraçBes altas de BAP e baixas de NAA. A avaliaça, no 
presente estudo, foi realizada fazendo-se a contagem do numero de brotaçbes obtidas por explante e nao o numero de genas formadas. Por esta raza, a avaliaço foi realizada 90 dies apos o infcio do cultivo dos explantes. Entretanto, as culturas foram inspecionadas semanalmente. Observouse que as gemas comecaram a surgir 3 a semanas apos a inoculaça dos explantes e continuaram a se proliferar ate aproximadamente 8 semanas apos o cultivo. As primeiras gemas a se formarem ja apresentavam um estadio mais desenvolvido en relacáo as gemas mais tardias. Geralmente, os explantes que formaram poucas gemas, não apresentaram a proliferaçăo de gemas tardias, permanecendo apenas aquelas que se formaram nas primeiras semanas de cultivo. Nos explantes que formaran um bom número de gemas, observou-se que estas surgiram en toda a superflcie do explente e tambem na face do explarte que estava em contato com o meio de cultura.

$$
\text { Apos } 60 \text { dias de Eultivo, todos os explantes }
$$

foram transferidos para mejos de cultura frescos, onde permaneceram por mais 30 dias e onde, tamben, as gemas tardias se deservolveram em brotaços. Nã foi observada a proliferaçáo de novas gemes, nestes explantes, apos a transferencia para meio fresco. Todos os meios de cultura que formaram gemas foram capazes de promover o alongamento destas gemas e a formação de brotaçbes (Figura 16 ).

Normalmente, tem-se utilizado uma relaçăo de altas concentraçbes de BAP e baixas de NAA. Entretanto, no 
trabal ho realizado por EDRISS a BURGER (1984) verificou-se a formaça direta de oemas en segmentos do epicotilo nas concentracbes de $0,5 \mathrm{mg} / 1$ de $\mathrm{BAP}$ e $1,0 \mathrm{mg} / 1$ de NAA.

BURGER \& HACKETT (1981) verificaram que os cotiledones dos cultivares de citrus estudados, regeneraram gemas somente quando uma grande proporçá $(100,1)$ de BAP foi utilizada en relaça a NAA.

No presente estudo, observou-se que houve formaça de brotaços em cotiledones em varias combinaçaes das concentraçes de BAP e NAA, inclusive en meio sem adicăo de requladores de crescimento.

4. 7. Multiplicação das brotaçóes adventicias (Experimento 8$)$

Brotaços adventicias, com aproximadamente I, 5 cm de altura, obtidas em meio de cultivo contendo 0,5 mgll de BAP e $1,0 \mathrm{mg} / \mathrm{l}$ de NAA, foram transferidas para meios de cultura contendo oiferentes concentraços de BAf para induzir a multiplicaça das brotaçes.

o princlpol objetivo da fase de multiplicaça - O de produzir o major numero de plantas possivel, no menor espaço de tempo. Entretanto, outro aspecto essencial é a qualidade e homogeneidade das partes aereas produzidas, o que vai determinar, em grande parte, o sucesso na fase seguinte de enraizamento. 
Tobel 10. Efeito de diferentes concentracbes de BAP a NAA na formaça de brotaçes adventicias na cultura de cotilfones de embribes nucelares.

Tratamentos
$(m g / 1)$

$B A P+N A A$

$\begin{array}{cc}0 & 0 \\ 0 & 0,5 \\ 0 & 1,0 \\ 0 & 1,5 \\ 0 & 2,0 \\ 0 & 2,5 \\ 0 & 3,0 \\ 0,5 & 0,0 \\ 0,5 & 0,5 \\ 0,5 & 1,0 \\ 0,5 & 1,5 \\ 0,5 & 2,0 \\ 0,5 & 2,5 \\ 0,5 & 3,0 \\ 1,0 & 0 \\ 1,0 & 0,5 \\ 1,0 & 1,0 \\ 1,0 & 1,5 \\ 1,0 & 2,0 \\ 1,0 & 2,5 \\ 1,0 & 3,0 \\ 1,5 & 0 \\ 1,5 & 0,5 \\ 1,5 & 1,0\end{array}$

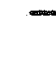

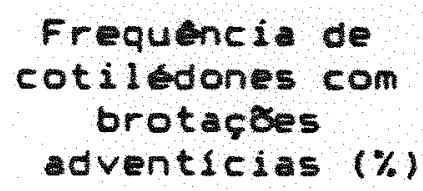

Frequencia de cotiledones com brotaços adventleias (\%)

N. nedio de brotaçes advent1cias/explante responsivo 
Tobela 10. Continuaço.

\begin{tabular}{|c|c|c|c|c|c|}
\hline \multicolumn{2}{|c|}{$\begin{array}{l}\text { Tratamentos } \\
(\mathrm{mg} / 1)\end{array}$} & \multicolumn{2}{|c|}{$\begin{array}{l}\text { Frequencia de } \\
\text { cotiliedones con } \\
\text { brotactes } \\
\text { adventicias }(\%)\end{array}$} & \multicolumn{2}{|c|}{$\begin{array}{l}\text { No medio de } \\
\text { brotaçes adventi- } \\
\text { cias/explante } \\
\text { responsivo }\end{array}$} \\
\hline 1,5 & 1,5 & 22,23 & (9)* & 3,0 & $\pm 1,4$ \\
\hline 1,5 & 2,0 & 33,34 & (9) & 3,0 & $\pm 1,0$ \\
\hline 1,5 & 2.5 & 0 & (9) & & - \\
\hline 1,5 & 3,0 & 22,23 & (9) & 2,5 & $\pm 2,1$ \\
\hline 2,0 & 0 & 22,23 & $(9)$ & 3,0 & $\pm 0,0$ \\
\hline 4,0 & 0,5 & 0 & $(9)$ & & - \\
\hline 4,0 & 1,0 & 11,12 & (9) & 4,0 & $\pm 0,0$ \\
\hline 2,0 & 1,5 & 22,23 & (9) & 3,5 & $\pm 0,7$ \\
\hline 2,0 & 2,0 & 22,23 & $(9)$ & 4,0 & $\pm 2,8$ \\
\hline 2,0 & 2,5 & 22,23 & (9) & 6,0 & $\pm 2,8$ \\
\hline 2,0 & 3,0 & 22,23 & (9) & 2,5 & $\pm 2,1$ \\
\hline 2,5 & 0 & 0 & (9) & & - \\
\hline 2,5 & 0,5 & 11,12 & (9) & 6,0 & $\pm 0,0$ \\
\hline 2,5 & 1.0 & 0 & (9) & & - \\
\hline 2,5 & \pm .5 & 0 & $(9)$ & & - \\
\hline 2,5 & 2,0 & 22,23 & $(9)$ & 10,5 & $\pm 0,7$ \\
\hline 2,5 & 2,5 & 22,23 & (9) & 2,0 & $\pm 1,4$ \\
\hline 2,5 & 3.0 & 22,23 & (9) & 3,0 & $\pm 2,8$ \\
\hline 3,0 & 0 & 0 & $(9)$ & & - \\
\hline $3,-$ & 0,5 & 11,12 & (9) & 4,0 & $=0,0$ \\
\hline 3,0 & 1,0 & 11,12 & (9) & 2,0 & $=0,0$ \\
\hline 3,0 & 1.5 & 44,45 & (9) & 2,0 & $=0,8$ \\
\hline 3,0 & 2,0 & 44,45 & (9) & 10,0 & $\pm 2,5$ \\
\hline 3,0 & 2,5 & 11,12 & (9) & 9,0 & $\pm 0,0$ \\
\hline 3,0 & 3,0 & 33,34 & (9) & 5,0 & $\pm 2,0$ \\
\hline
\end{tabular}

* Número total de explantes inoculados depois de descartados os frascos contaminados 
Segundo KITTO \& VUNG (1981) proliferecto de gemas en apice neristematico - influenciada pelo genotipo, fonte de explante, citocinina, nlvel de sacarose e intensidade luminosa.

As citocininas constituem o grupo de requladores de crescimento indispensavel para a quebra de dominancia apical induça de proliferaço de gemas axileres. o BAP tem sido muito eficaz para promover multiplicaca em diversas especies e parece ser a citocinina mais adequada paramultiplicaço de partes aereas e induçao de eemas adventscias (GRATTAPAGLIA \& MACHADO, 1990).

No presente trabalho, estudou-se o efeito da concentraçao de BAF, no meio de cultura, na formação de gemas em brotaçás. A Tabela 11 apresenta os valores obtidos para porcentagem de explantes com proliferaçá de gemas e numero medio de gemaslexplante, $B$ semenas de cultivo. observou-se que a concentraça de $3 \mathrm{mg} / 1$ de BAP induziu a produçá de gemes em $100 \%$ dos explantes e um numero $=$ medio $(12,12)$ gemas por explante. As concentracbes de citocininas para a multiplicação estão, en geral, entre 0,1 e 5,0 mgl nos diferentes tratalhos (GRATTAPAGLIA \& MACHADO, 1990 ). MATSUMOTO \& YAMAGUSHI (1983) obtiveram maior multiplicaça de gemas adventicias em meio contendo $1,0 \mathrm{mg} / 1$ NAA e $5 \mathrm{mg} / 1$ de BAP. 
Tabela 11. Efeito da concentraça de BAP na multiplicaço de brotacbes adventicias. Avaliacto realizada 8 semanas apos o inlcio do cultivo.

\begin{tabular}{lcc}
\hline $\begin{array}{c}\text { Tratamentos } \\
(\text { mg/1) }\end{array}$ & $\begin{array}{c}\text { Explantes }(*) \\
\text { com gemas } \\
(\%)\end{array}$ & $\begin{array}{c}\text { No medio } \\
\text { demas/explante } \\
( \pm \leq)\end{array}$ \\
\hline$M T$ & 62,5 & $1,625 \pm 1,59$ \\
$M T+B A P-1,0$ & 87,5 & $6,125 \pm 4,10$ \\
$M T+$ BAP-2,0 & 87,5 & $7,125 \pm 3,83$ \\
$M T+B A P-3,0$ & 100,0 & $12,125 \pm 3,04$ \\
$M T+B A P-4,0$ & 100,0 & $11,125 \pm 4,35$ \\
$M T+B A P-5,0$ & 87,5 & $8,375 \pm 4,98$ \\
\hline
\end{tabular}

(*) Explantes = brotaçoes com $\cong 1,5 \mathrm{~cm}$, total de 8 explantes por tratamento.

Enbora nem sempre sejam necessarias no mejo de multiplicaço louoirin e Lepoivre", citados por GRATTAPAGLIA \& MACHADO, 19901, as auXinas sao utilizadas com o intuito de estimular o crescimento das partes eereas. Entretanto, cono fol observado no Experimento 7, o alongamento de parte aerea foi obtido en todos os mejos que formaram gemas adventicias. No presente estudo, observouse que todas as concentraçós de BAP promoveram o alongamento das gemas obtidas.

QUOIRIN, M. \& LEPOIVRE, P. Etude de milieux adaptes auX cultures in vitro de Prunus. Acta Hort., 78: 437-442, 1977. 
As gemas obtidas eram gemas axilares e gemas adventicias formadas na regixo de transicao, entre parte aerea e raiz da brotaço principal (Figura 17). As gemas comegaram a surgir por volta da segunda semana de cultivo e aumentaram em numero apos 8 semanas. As gemas formadas, nas primeiras semanas de cultivo, desenvolveram-se em brotaçes, mesmo estando ligadas a brotaça principal e,posteriormente, foram transferidas para meio de eultivo para induzir o enraizamento.

4. 8. Indução de enrai zamento em brotaçßes adventicias (Experimento 9)

A Tabela 12 apresenta as porcentagens medias de enraizamento obtidas em brotaçoes inoculadas en meio basico MT, suplementado com diferentes reguladoresde crescimento e suas combinaçzes.

$$
\text { Verificou-se que o meio suplementado com } 2 \text {, }
$$

mg/l de NAA produziU a major porcentagen de enrajzamento $(58,33 \%)$. Este resultado esta de acordo con os resultados ODtidos por MATSUMOTO \& YAMAGUSHI (1983) E EDRISS \& BURGER $(1984)$.

- regulador de crescimento, GAs, não promoveu - enraizamento em nenhuma concentraçăo utilizada e provocou um estiolamento nas brotaçbes. Concentraçbes de NAA abaixo de $0,5 \mathrm{mg} / 1$ năo promoveram o enraizamento. 
Tabel a 12. Porcentagen modia de enraizamento, de brotacaes en meio MT suplementado con varios reguladores de crescimento. Avaliaça 4 semanas apos o inleio do cultivo.

Tratamento

( $\mathrm{mg} / \mathrm{I})$

\section{Enraizamento}

(\%)

\begin{tabular}{|c|c|c|}
\hline NAA & $-0,0$ & 0 \\
\hline NAA & $-0,1$ & 0 \\
\hline NAA & $-0,3$ & 0 \\
\hline NAA & $-0,5$ & 11,11 \\
\hline NAA & $-1,0$ & 22,22 \\
\hline NAA & $-2,0$ & 58,33 \\
\hline NAA & $-3,0$ & 11,11 \\
\hline NAA & $-5,0$ & 11,00 \\
\hline GA & $-1,0$ & 0 \\
\hline GA3 & $-5,0$ & 0 \\
\hline GAs & $-10,0$ & 0 \\
\hline NAA- & $-0,1+1 B A-2,0$ & 16,67 \\
\hline NAA- & $-1,0+I B A-2,0$ & 16,67 \\
\hline NAA- & $-5,0+I B A-2,0$ & 25,00 \\
\hline NAA- & $-5,0+I B A-2,0$ & 20,83 \\
\hline NAA - & $-5,0+B A P-0,1$ & 0 \\
\hline
\end{tabular}

Existem diversos fatores que podem afetar enraizamento de brotaços tais como a concentraça de macronutrientes no meio de cultura, concentraça de sacarose e agar, tipos e concentraçós de auxinas. Compostos fenólicos podem atuar como cofatores de enraizamento como por exemplo, 
- floroplucirol. As condicbes de incubacro tambem poden efetar o enraizamento.

Estudos realizados por KITTO \& VUNG (1981) na eultivar Citrange Carrizo, mostraram que o NAA favoreceu - enraizamento quando comparado com IBA OU IAA. Das concentraços de NAA estudadas $(0,2,1,0$ e $5,0 \mathrm{mg} / 1)$ somente a concentraça $1,0 \mathrm{mg} / 1$ favoreceu a formaça de ralzes. outros fatores foram estudados, tais como: concentracao de agar, sacarose, utilizaça de suco de laranja, intensidade luminosa e fonte de mitrogenio no meio de cultura. Somente a diminuição da concentraça de agar de 2,0 para $0,5 \%$ produziu um aumento na resposta ao enreizamento das brotaçoses.

De acordo com os valores apresentados na Tabela 12 , as porcentagens de enraizamento variaram de 0 a $58,33 \%$ PASQUAL (1985) encontrou porcentagens de enraizamento de $12,5 \%$ a $96,0 \%$ pera o cv. Valencla e valores de 0 a $63,5 \%$ para o cv. Trifoliata nos diferentes meios de cultura estudados. E possivel que, un genbtipo seja mas responsivo que outro quanto ao enraizamento.

4. 9. Analises histologicas (Experimento 10 )

Os explantes utilizados nas analises histologicas eran cotiledones de embribes nucelares, obtidos in vitro, com 30 dias de idade sao mostrados na figura 15. 
Cortes transversais de folha cotiledonar, antes da inoculacáo no meio de cultura, revelam que a epiderme - constitulda por celulas compactas com núleo grande; o mesofilo homogeneo e se caracteriza por apresentar colulas isodiametricas arranjadas de maneira justaposta; os feixes vasculares sao colaterais (Figura 19, seta a).

YEUNG et ali (1981) verificaram que quando os cotiledones estao ainda no estado meristematico de crescimento, a adição de BAP do meio de cultura induz novos tecidos meristemáticos, porque as celulas epidermicas e subepidermicas nao estao completamente oiferenciadas, sendo então, mais suscetiveis as citocininas exogenas.

A analise de cortes transversais do explante, mantido por 4 semanas em meio de cultura (MT + 3 mg/l de BAP $+2,5 \mathrm{mg} / 1$ de $N A A)$, revelou que em algumas areas, a estrutura interna permanecia inalterada, verificando-se apenas o acumulo de amido em algumas celulas subepidermicas (Figura 20, seta $a$ ).

Porem, em outras areas, a epiderme e as caraoas subepidermicas, eram substituides por un meristeme semelharte e um cambio de cicatrizaço fFigura 21 , seta a).

Neste meristeme neoformado observou-se a ocorrencia de meristenosdes (Figura 22 , setas a e b).

THORPE \& MURASIGE (1968), por meio de observaçes histoquimicas, observaram uma forte correlaço entre 
- acumulo de amido nas celulas - iniciacro de primordios vegetativos. Os grasos de amido foram observados antes do inscio de qualquer desenvolvimento organizado, e nos locais de maior acumulo, posteriormente, formaram-se primordios. Segundo os autores, o tratamento dos tecidos con giberelina evitou o acumulo e a formaczo de primórdios, possivelmente devido a produça "de novo" da enzima $\alpha$-amilase. Em trabalno posterior, THORPE MEIER (1972) constataram grande relaça entre o acúmulo de amido, o aumento na taxa de respiraço e a formação de gemas.

Apos 60 dias em meio de cultura, podia-se observar várias formaçbes ao longo da superficie do explante (Figura 23 , seta a).

A anélise dos cortes longitudinais do explante passando pelas referidas formaçbes revela que estas são gemas vegetativas, caracterizadas por apresentarem meristema apical protegido por primordios foliares (Figura 24, seta a), glandulas de bleo (Figura 24 , seta b). As gemas apresentovam meristema vascular conectado ao explante.

As analises revelam que a neoformaçao de gemas ocorreu partir das estruturas meristematicas comentadas anteriormente, nå houve a formação de calo. Portanto, as gemas neoformadas sá exbgenas na origem.

RUMARY et alii (1986) estudaram a formaçăo de gemas adventicias em epicotilo cultivado in vitro (White \& Black Spruce). Os autores observaram 3 fases distintas na 
formaça dos brotosi induça da divisáo celular em areas denominadas "lvo", formaço de neristenoidese, finalmente, o desenvolvimento de gemas. Tais observaçbes concordan com as analises realizadas no presente estudo.

Os autores acima citados comentam que as divisbes celulares ocorriam na periferia do explante levando a formaçăo de numerosos meristemoides e, finalmente, de brotos adventicios. Tais brotos desenvolviam un sistema vascular que tornou-se conectado ao sistema vascular do explante. As mesmas observaçbes foram verificadas no presente estudo.

Ainda, RUMARY et alii (1986) comentam que a induça de gema teve lugar em tecidos do explante sem a formaçăo significativa de calo. Assim, segundo os autores, provavel que a fidelidade genetica tentia sido mantida nas plartulas desenvolvidas.

PATEL \& BERLYN (1982) comentam que as gemes formadas nos calos podem mostrar mudangas no nivel de ploida; aqueles formadas oiretamente dos explantes sao meis estávels geneticamente (PATEL \& THORPE, 1984).

Uma vez que, rieste estudo, as gemas se organizaram diretamente no explante sem a proliferaça do tipo calo, éprovavel que, a fidelidade genetica des plantulas formadas tentia sido mantida. 
As oemas adventicias poden ocorrer in vivo ou in vitro en diferentes partes da planta, frequentemente se originan de forma indireta a partir de calos, mas tambem diretamente de tecidos mais ou menos diferenciados. Elas podem ser de origem endogena ou exsgena. a número de celulas a partir do qual os primordios das gemas adventicias se originam varia de um a muitos. Este ponto e de grande importancia para os trabalhos de melhoramento genetico utilizando induça de mutaços, devido a ocorrencia de quimerISMO (BROERTJES \& VAN HARTEN, 1988 ). 


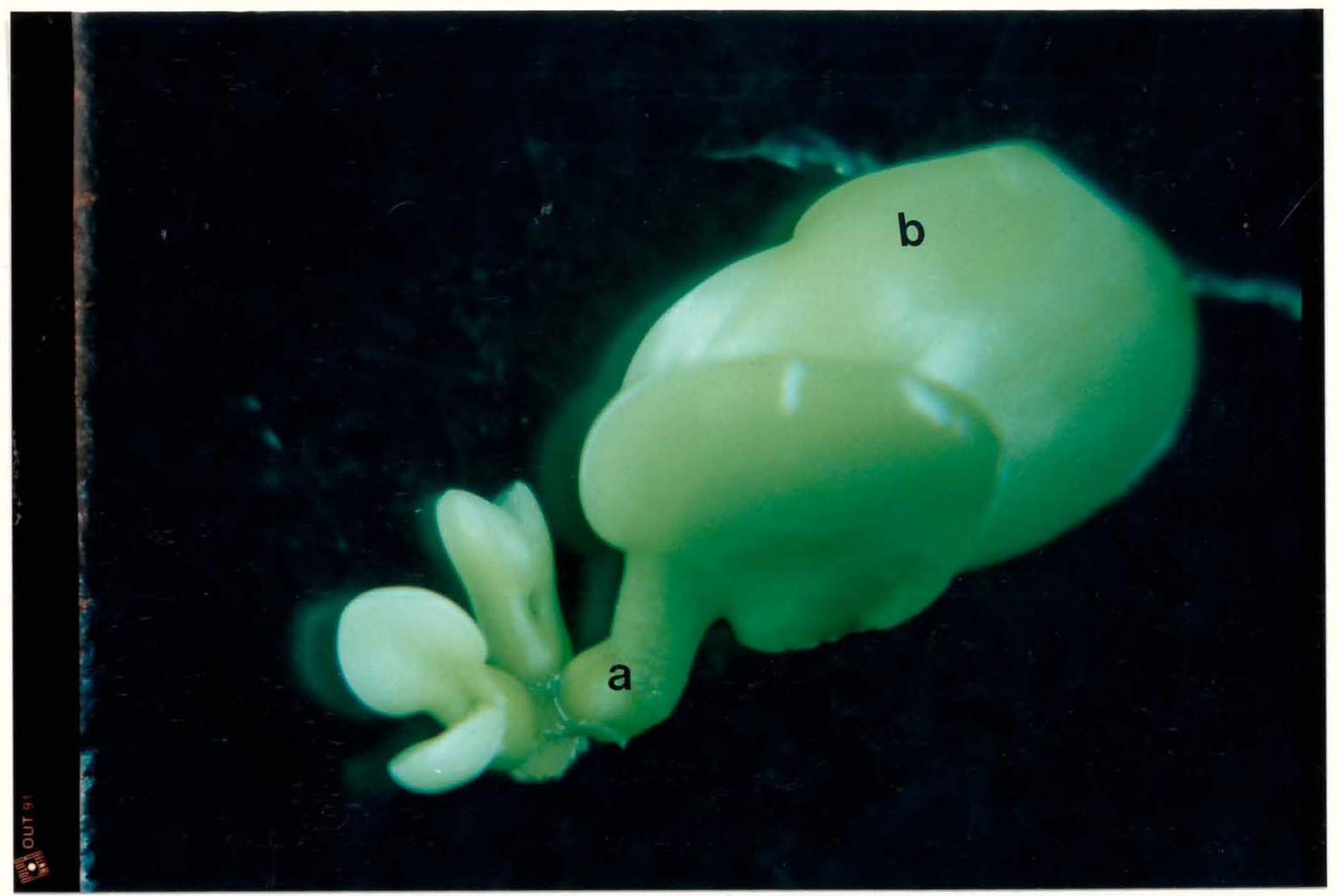

Figura 15. Embrião nucelar cotiledonar (a). Cotilédones utilizados na indução de gemas adventicias (b) $(\times 10)$.

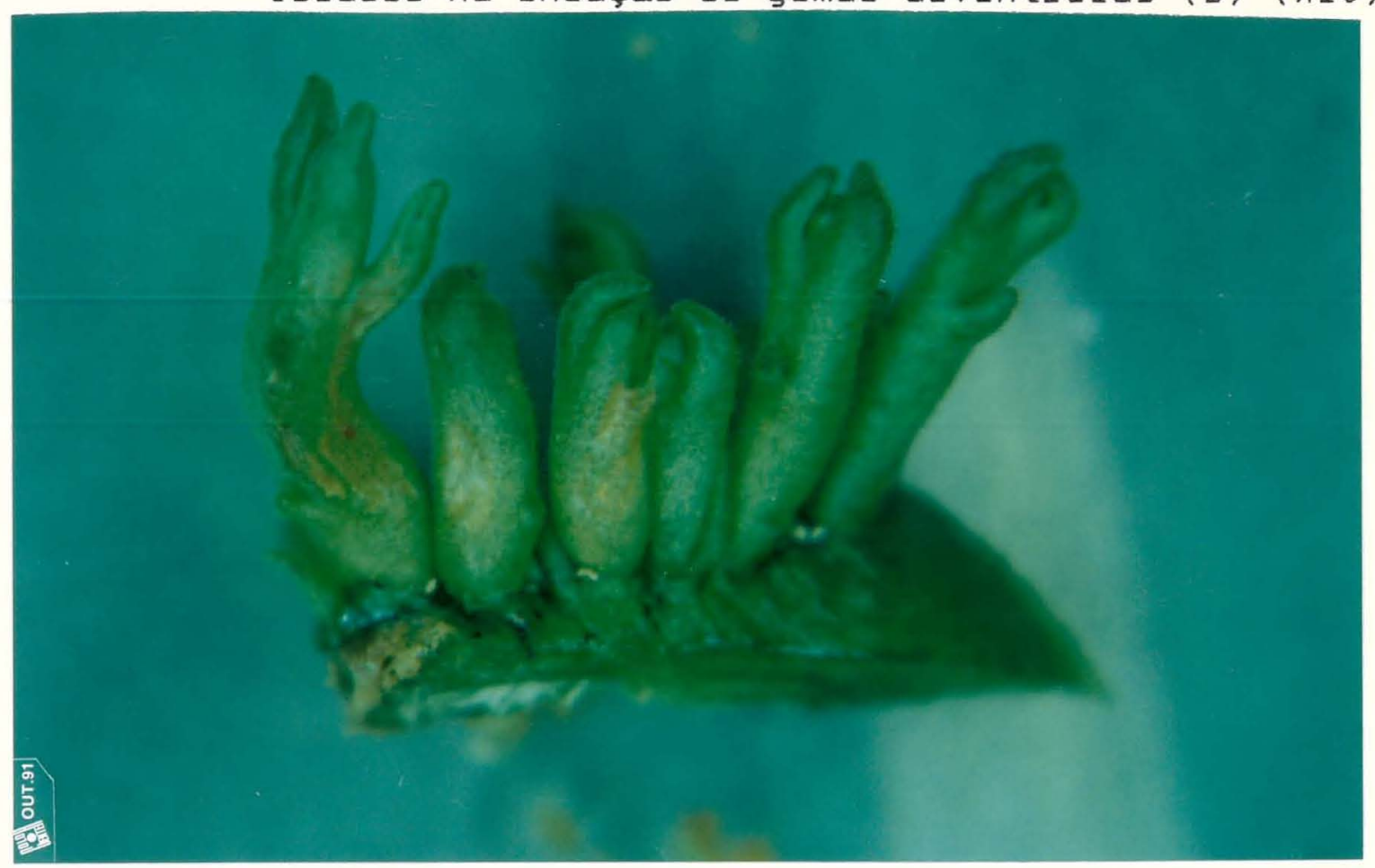

Figura 16. Desenvolvimento de brotaçžes adventicias em cotilédones de embrizes nucelares $(\times 10)$. 


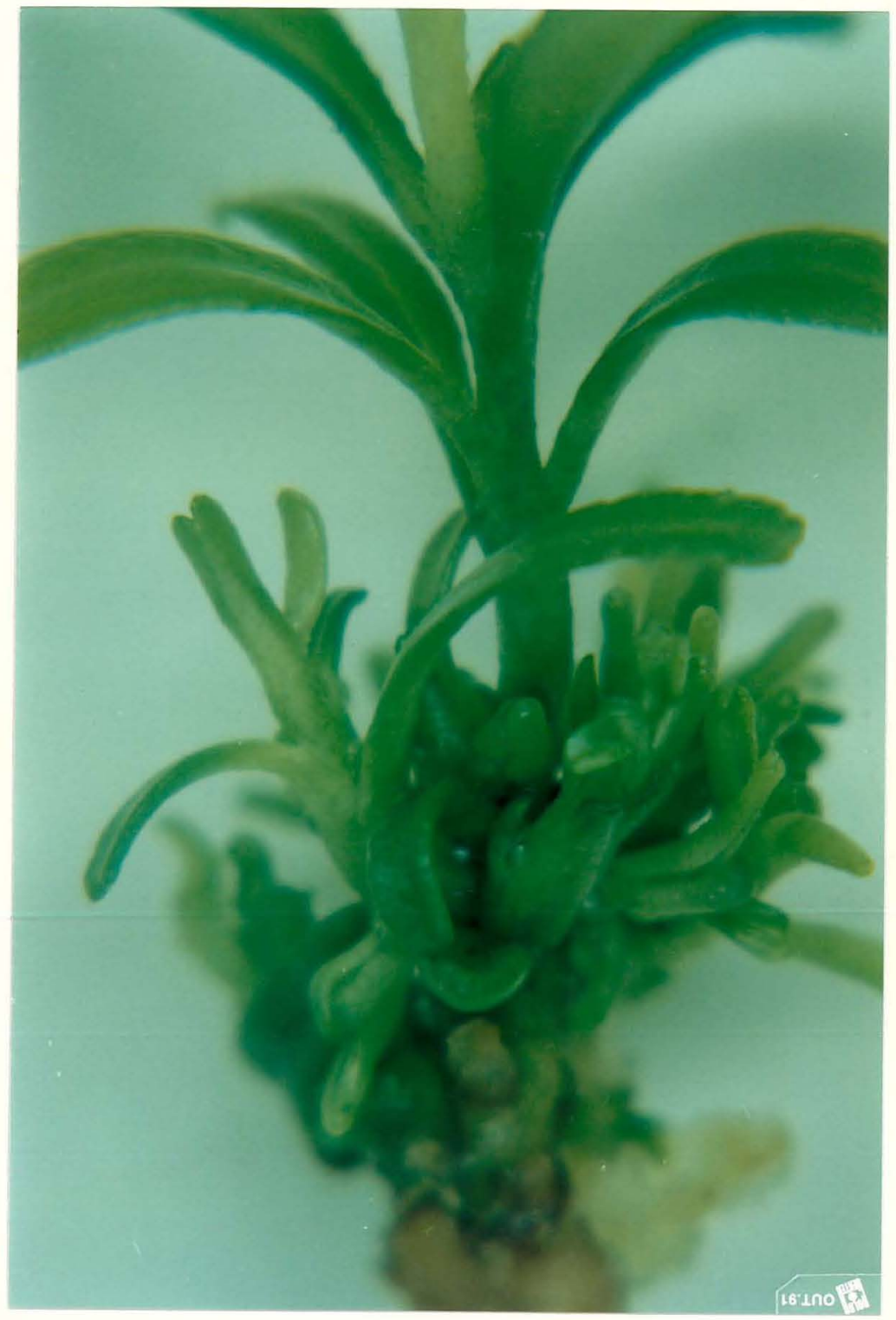

Figura 17. Multiplicaçăo de brotaçôses adventicias em meio suplementado com $3 \mathrm{mg} / \mathrm{l}$ de $\operatorname{BAP}(x 8)$. 


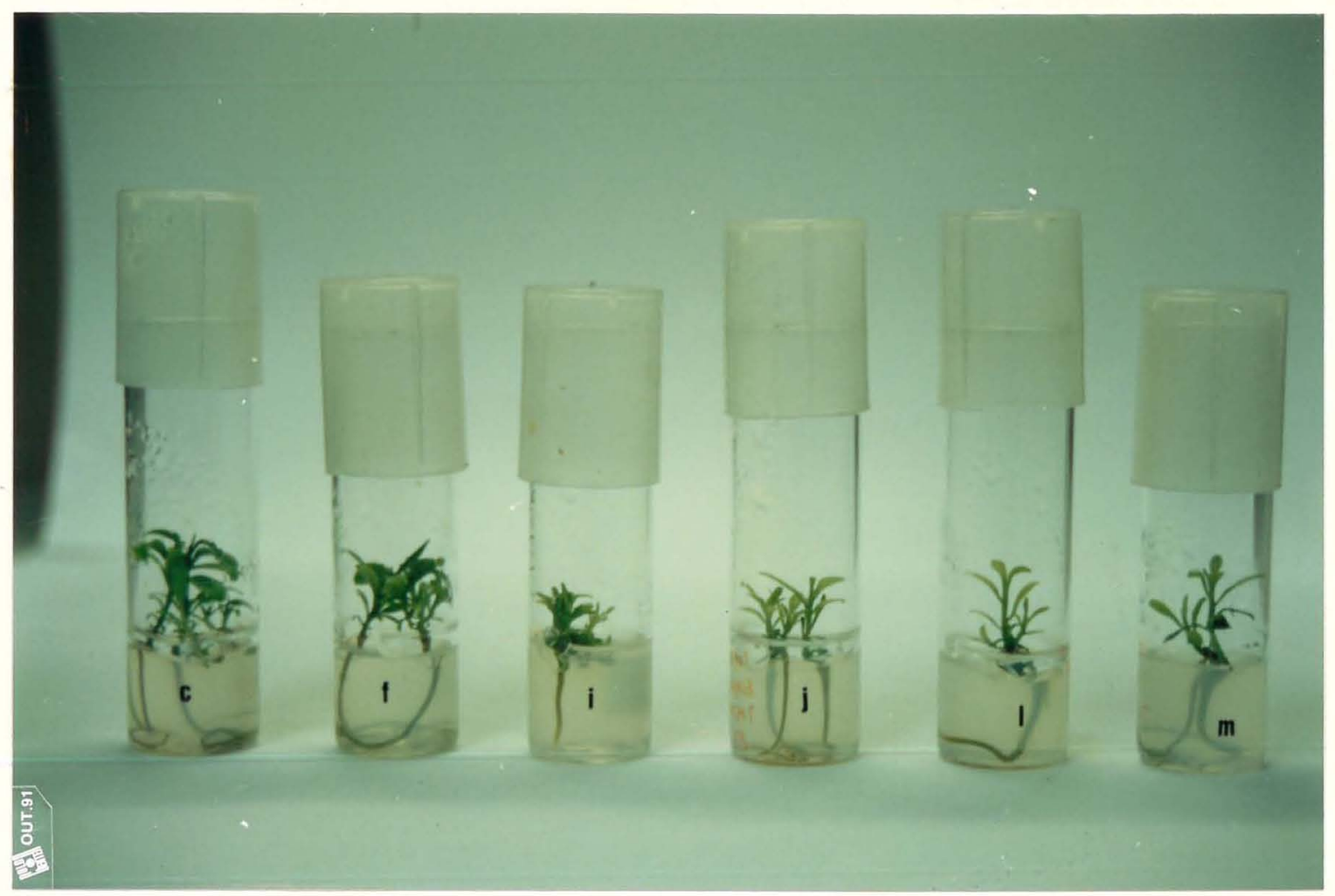

Figura 18. Enraizamento de brotações em diferentes meios de cultura 4 semanas apos o inicio do cultivo.

(c) $M T+N A A(0,5 \mathrm{mg} / 1) ;$ (f) MT + NAA $(2,0$

(i) $M T+N A A(0,1 \mathrm{mg} / 1+\operatorname{IBA}(2,0 \mathrm{mg} / 1) ;(j)$ $M T+N A A(1,0 m g / 1)+I B A(2,0 m g / 1)$, (1) MT $+\operatorname{NAA}(1,0 \mathrm{mg} / 1)+I B A(5,0 \mathrm{mg} / 1) ;(\mathrm{m}) \mathrm{MT}$ + NAA $(5,0 \mathrm{mg} / 1)+I B A(2,0 \mathrm{mg} / 1)$. 


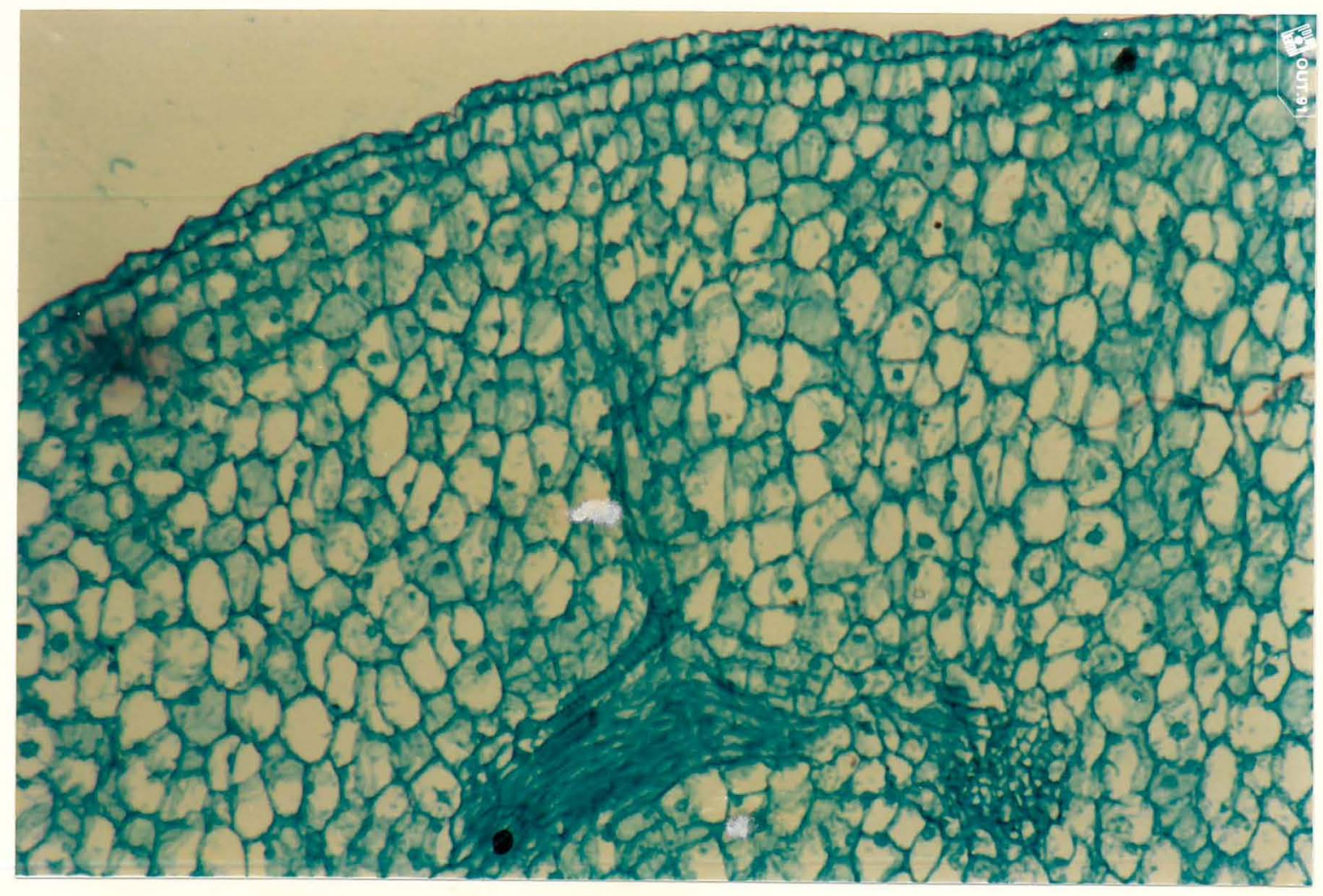

Figura 19. Corte transversal da folha cotiledonar, antes da inoculação no meio de cultura, revelarido que a epiderme é constitulda por células compactas com núcleo grande; o mesofilo é homogéneo e se caracteriza por apresentar celulas arranjadas de maneira justaposta; os feixes vasculares são colaterais (16 161,25$)$. 


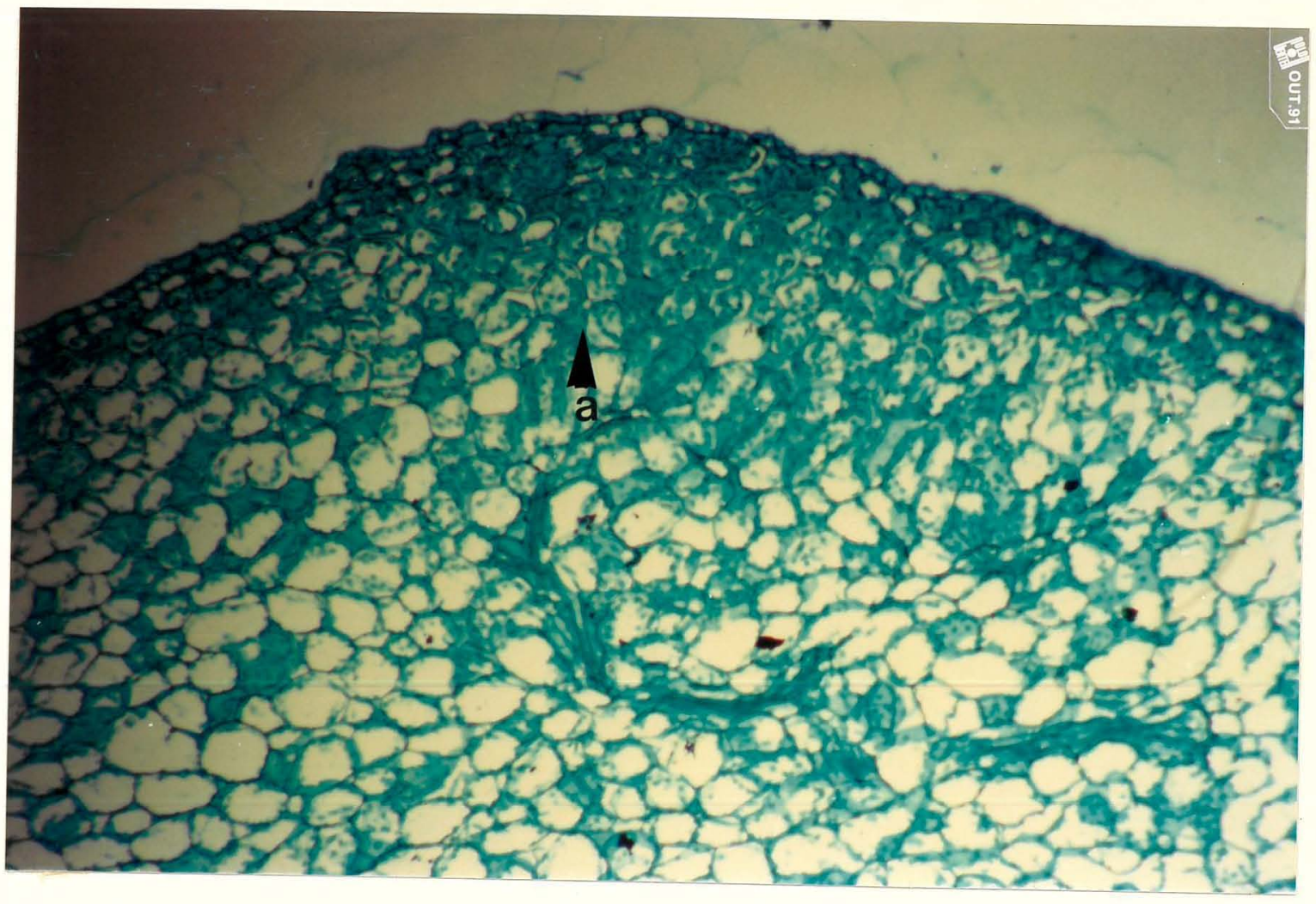

Figura 20. Corte transversal do explante, mantido por 4 semanas em meio de cultura (MT + $3 \mathrm{mg} / \mathrm{l}$ de BAP + $2,5 \mathrm{mg} / 1$ de $N A A)$. Observa-se acúmulo de amido em algumas células subepidérmicas (a) $(6,3 \times 1,6)$. 


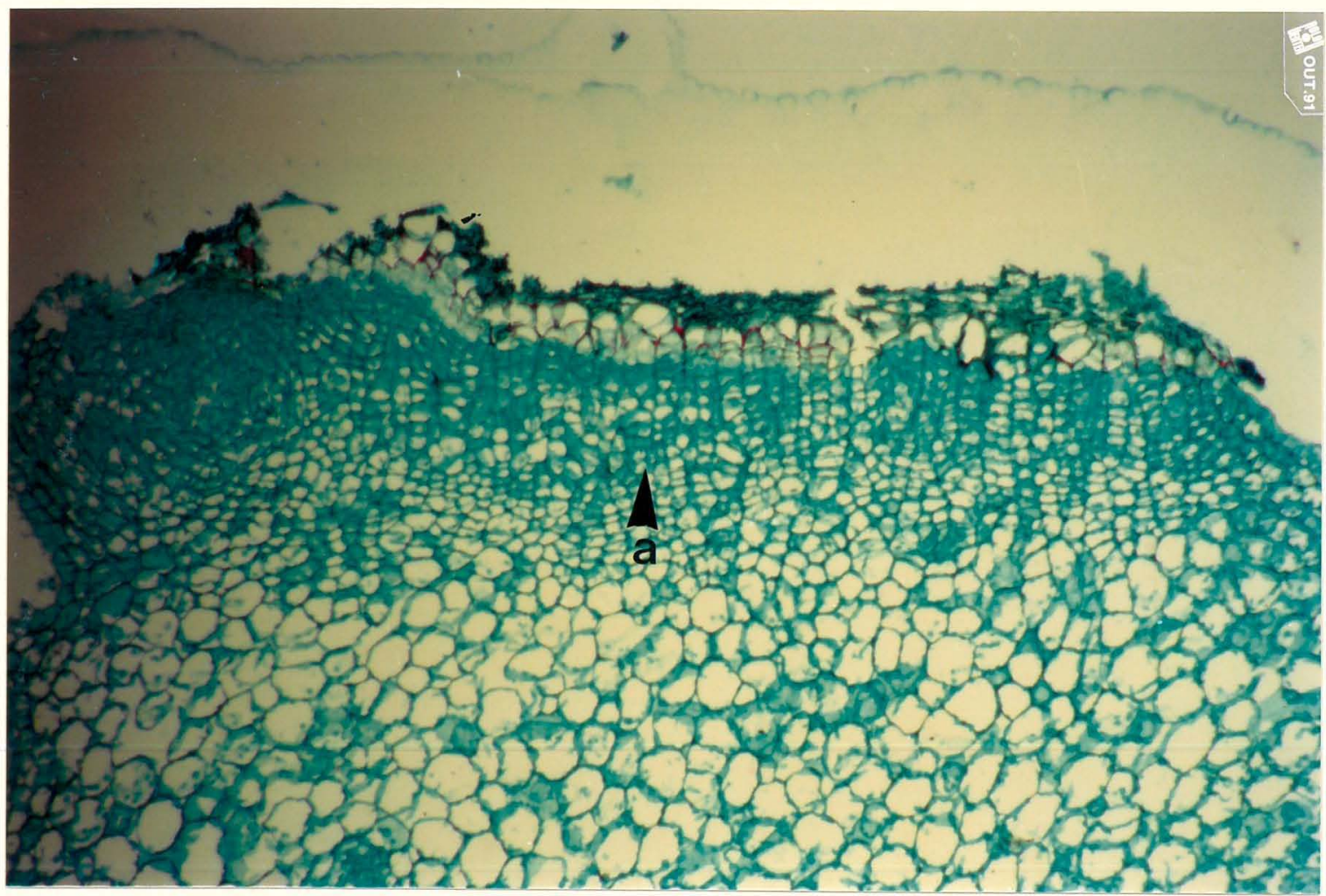

Figura 21. Corte transversal do explante, mantido por 4 semanas em meio de cultura (MT + $3 \mathrm{mg} / \mathrm{l}$ de BAP + $2,5 \mathrm{mg} / 1$ de $N A A)$. Observa-se que, em algumas áreas, a epiderme e as camadas subepidermicas, eram substituidas por um meristema semelhante a um câmbio de cicatrizaçăo (a) $(16 \times 1,25)$. 


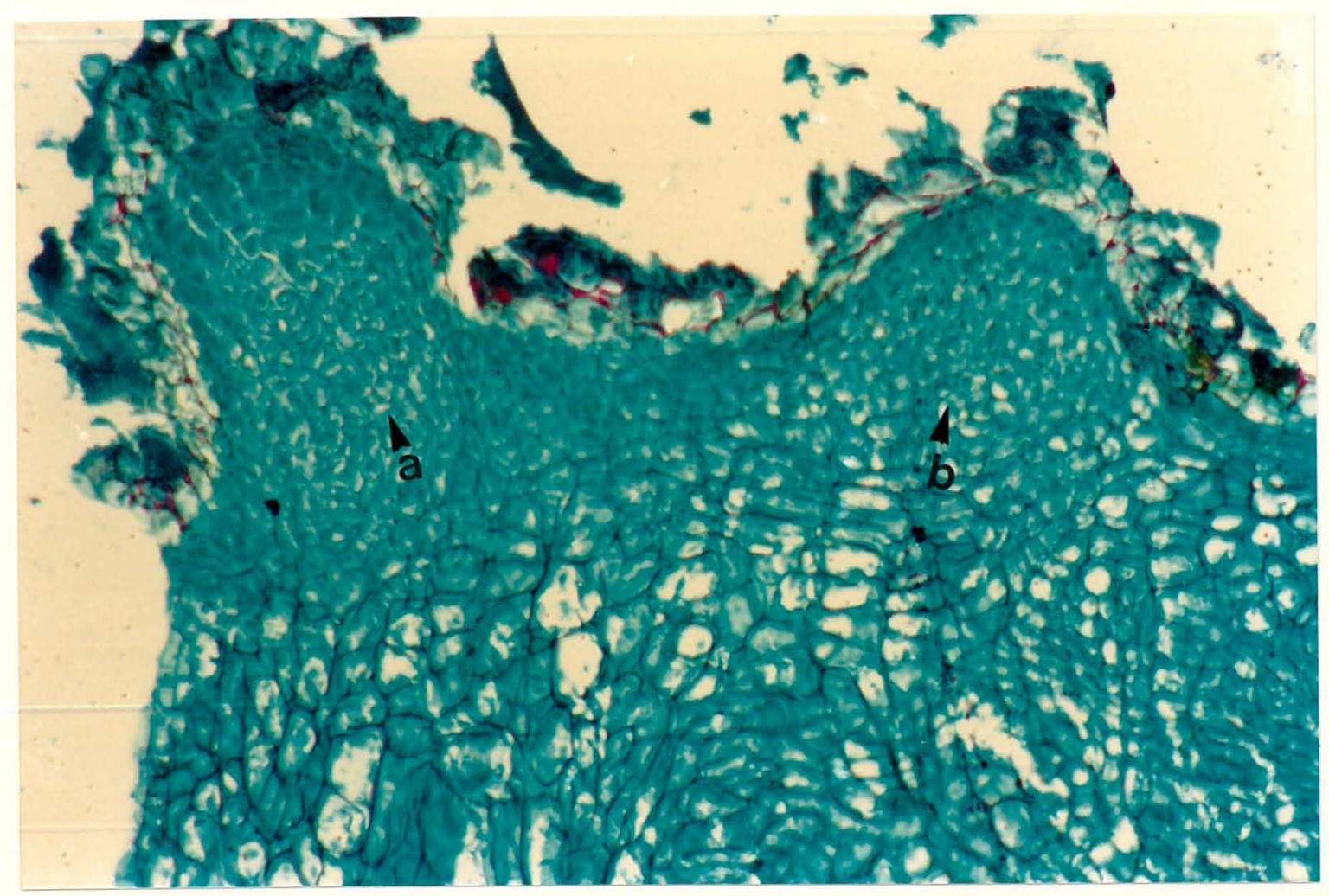

Figura 22. Observa-se no meristema neoformado, a ocorrência de meristemóides (a e b) $(16 \times 1,25)$. 


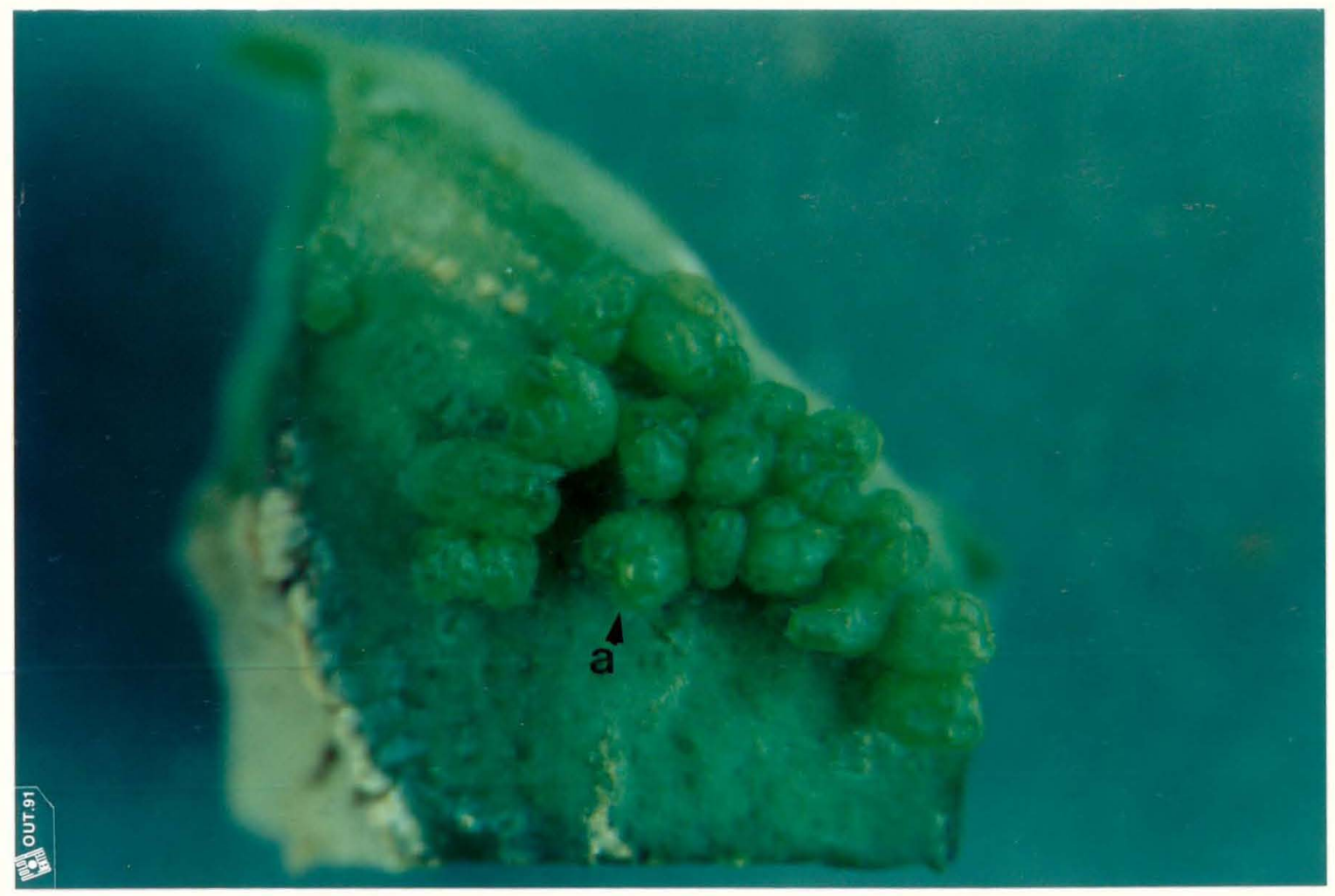

Figura 23. Brotações formadas ao longo da superficie do explante (a) após 60 dias em meio de cultura $(\times 10)$. 


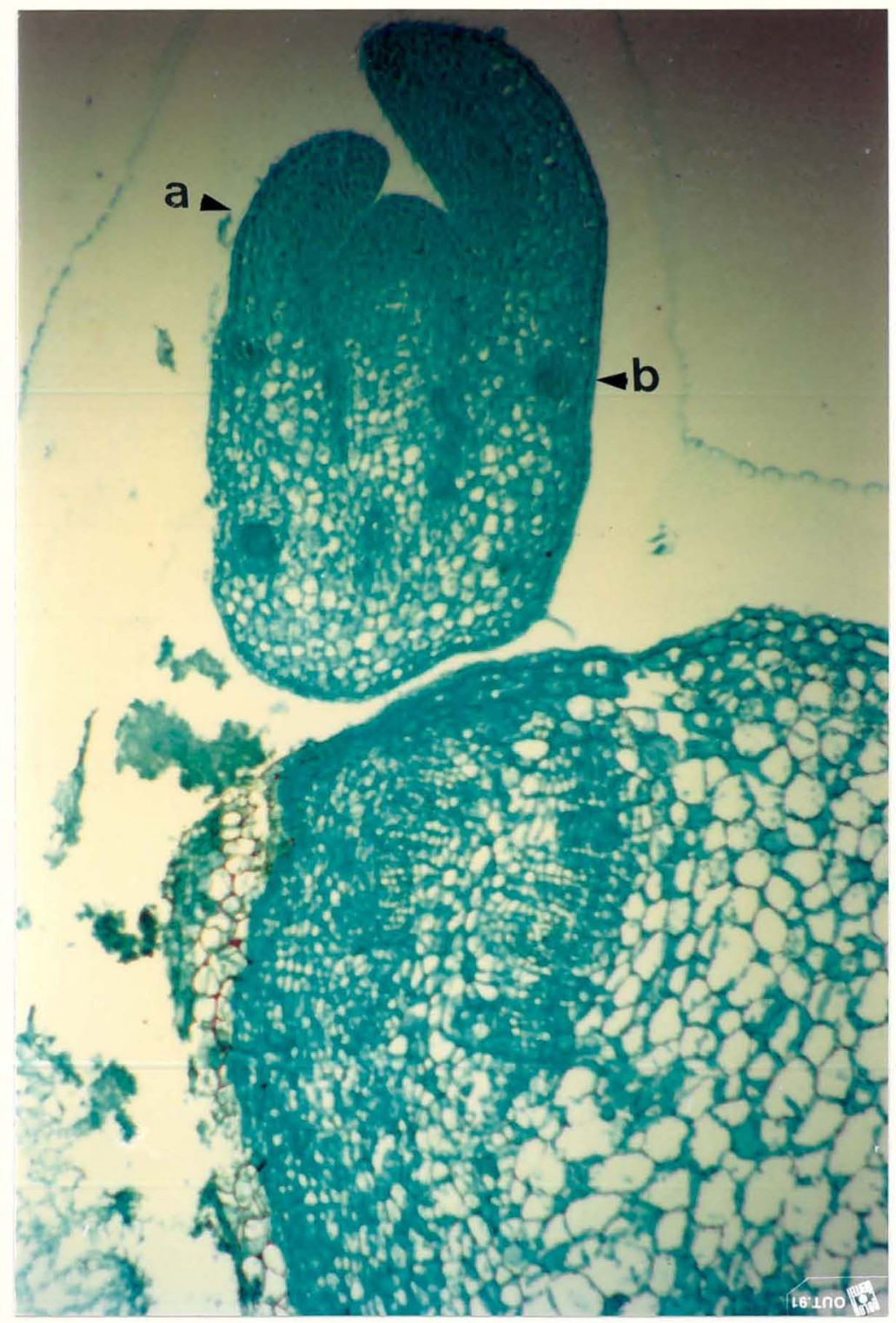

Figura 24. A análise dos cortes longitudinais do explante após 60 dias de cultivo, revela a formação de gemas vegetativas caracterizadas por apresentarem meristema apical protegido por primórdios foliares (a), glândulas de olleo (b) $(6,3 \times 1,25)$. 


\subsection{Obtençuo de protoplastos}

\section{(Exper1 nto 112}

Atraves dos resultados apresentados na Tabela 13, observa-se que os meios de maceracao e lavagen correspondentes a meio 1 (item 3.2 .11 ) foram os mais eficientes no isolamento dos protoplastos. O melhor tempo de digestzo enzimatica toi o de 10 horas apos a inoculaço dos calos em meio de maceraça. Os outros tratamentos, que contem concentraçes menores de enzimas, aumentaram a produçao de protoplastos de acordo com o tempo de digestáo enzimatica. tratamento denominado meio 1 causou uma diminuiçăo no número de protoplastos obtidos por ml na avaliação realizada apos 15 noras de digestzo enzimatica (Figura 25). Este fato deve ter ocorrido, provavelmente, porque a concentraçao de celulase no meio de maceraça deste tratamento era pelo menos 10 vezes maior que nos outros tratamentos; erovavel que, apos un certo tempo a alta concentraçăo desta enzima provoque danos a membrana plasmatica dos protoplastos isolados, diminuindo o rendimento do tratamento enzimatico. Con os outros tres tratamentos, possivel que, aumentando o tempo de digestao enzimatica, o rendimento possa ser maior. Seria, entzo, conveniente realizar um estudo ampliando o tempo de digestão enzimatica nestes casos. 
Tabela 13. Rendimento* medio de protoplastos isolados em diferentes tratamentose periodos de digestao enzimática.

\begin{tabular}{llll}
\hline Tratamentos & 5** & 10 & 15 \\
\hline Meio 1 & $3,4 \times 10^{5} \mathrm{a}$ & $10,34 \times 10^{5} \mathrm{a}$ & $9,16 \times 10^{5} \mathrm{a}$ \\
Meio 2 & $1,96 \times 10^{5} \mathrm{~b}$ & $6,18 \times 10^{5} \mathrm{~b}$ & $8,48 \times 10^{5} \mathrm{a}$ \\
Meio 3 & $0,51 \times 10^{5} \mathrm{c}$ & $5,40 \times 10^{5} \mathrm{~b}$ & $8,24 \times 10^{5} \mathrm{a}$ \\
Meio 4 & $1,54 \times 10^{5} \mathrm{~b}$ & $3,60 \times 10^{5} \mathrm{C}$ & $5,29 \times 10^{5} \mathrm{~b}$ \\
\hline
\end{tabular}

Medias seguidas das mesmas letras nao diferem significativamente entre $s i$ pelo teste Tukey - $5 \%$.

* rendimento = numero de protoplastos/grama de calo

* tempo de digestzo enzimática em horas

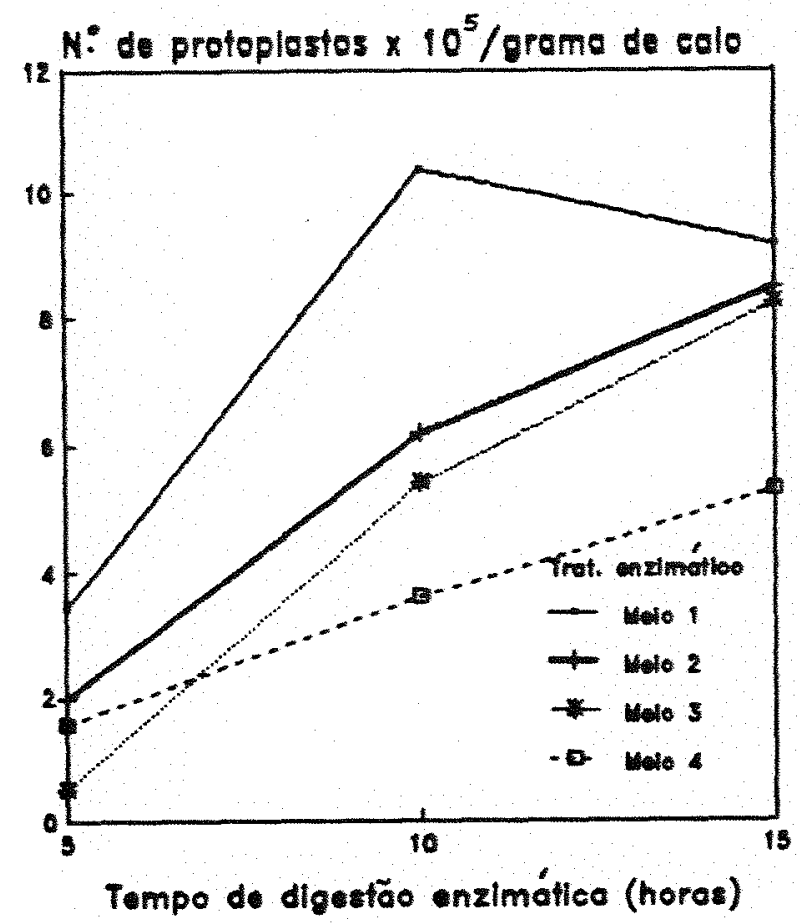

Figura 25. Representação grafica do efeito de diferentes tratamentos enzimáticos no rendimento do processo de isolamento de protoplastos. 
A utilização de pectinase, no lugar de macerozyme, outra enzima com atividade pectinolitica, nao foi prejudicial aos protoplastos, neste experimento. VARDI et alii (1982) observaram que a enzima macerozyme produziu melhores resultados na maioria dos oito cultivares estudados.

Os meios de maceraçăo e lavagem utilizados no tratamento 1 foram extraldos do protocolo estabelecido para protoplastos do cV. Pera (GOLDMAN, 1988). Neste caso, o tempo otimo de digestao encontrado foi de 5 horas. Entretanto, no presente trabalio, verificou-se que este tempo de digestao enzimatica resultou em um rendimento baixo de protoplastos. Porem, é preciso levar em consideraçăo que neste experimento os calos tiveram origem a partir de nucelos cultivados em meios MT contendo $10 \mathrm{mg} / 1$ de BAP e, no trabalio realizado por GOLDMAN (1988), os calos se originaram a partir do hipocotilo em meio MT sem suplementaça de reguladores de crescimento.

Fatores tais como, combinaça apropriada de enzimas e tempo de digestão enzimática, deven ser determinados empiricamente para cada linhagem de calo (VARDI \& GALUN, 1988; GROSSER \& GMITTER, 19901.

o principal objetivo deste experimento foi verificar qual protocolo e qual o tempo de digestao enzimática resultavam em maior eficiencia na obtençăo de protoplastos, para que fosse possivel dar continuidade aos tra- 
bal hos com o cultivo de protoplastos e estudo da radiossensitividade dos mesmos. Observou-se que o protocolo estabelecido por GOLDMAN (1988) apresentou os melhores resultados nos periodos de digestáo enzimatica estudados. Este protocolo foi o escolnido para dar prosseguimento aos trabalios com protoplastos e o tempo de digestao enzimática que produziu o melhor resultado, foi o de 10 horas. Obteve-se um rendimento de $1,03 \times 10^{\circ}$ protoplastos/grama de calo, o que está de acordo com os valores encontrados para protoplastos isolados a partir de calos embriogenicos em citrus (VARDI et alii, 1975; GOLDMAN, 1988; HIDAKA \& KAJIURA, 1988).

4.11. Viabilidade dos protoplastos (Experimento 12)

Para determinar a viabilidade de protoplastos isolados, podem ser utilizados corantes como Evans Blue (KANAI \& EDWARDS, 1973) e feNOIsafranina (KARANARATNE \& SCOTT, 1981, adicionados a uma amostra apos purificação. Protoplastos intactos sao capazes de excluir os corantes, enquanto protoplastos quebrados e mortos são permeáveis a eles. o azul de metileno ém corante que tem sido amplamente utilizado em protoplastos vegetais. Este corante reduzido por celulas vivas que se coram em amarelo (HoOLEY, 1982, citado por GOLDMAN, 1988). 0 diacetato de fluoresceina (FDA) numa concentração final do reagente de 
$0,01 \%(p / v)$ tamben bastante utilizado no teste de viabilidade. o diacetato de fluoresceina lum composto nao fluorescente, náo polar e bastante permeável atraves da membrana plasmatica. Apos absorça, as esterases presentes no citoplasma dos protoplastos viaveis, hidrolizam esta substancia liberando a fluoresceina, que e fluorescente, polar e não se movimenta com facilidade atraves do plasmalema, acumulando-se no citoplasma da celula viva (LARKIN, 1976). A fluorescencia pode ser detectada depois de 5 minutos de reaça, atraves de microscopia de fluorescencia.

No presente trabalho, o estudo de viabilidade foi realizado somente em protoplastos isolados de acordo com - melhor protocolo estudado no item 4.10 (Experimento 11 ) e que corresponde ao Tratamento 1. A viabilidade foi analisada, logo após a purificaça dos protoplastos, utilizando-se diacetado de fluoresceina em trés diferentes concentraçbes finais do reagente. as resultados deste experimento estao apresentados na Tabela 14.

As porcentagens de viabilidade obtidas $(80,68$ a $84,03 \%, 1090$ apos a purificaça, estao dentro da faixa de viabilidade observada por GOLDMAN (1988), que obteve porcentagens variando de 79,47 a $89,50 \%$ para o ev. Pera,utilizando - corante azul de metileno. 
Tabela 14. Viabilidade dos protoplastos em diferentes diluiçres de diacetato de fluoresceina em meio de lavagem.

\begin{tabular}{lccc}
\hline Diluiço & $\begin{array}{c}\text { Sem } \\
\text { fluorescencia }\end{array}$ & $\begin{array}{c}\text { Com } \\
\text { fluorescencia }\end{array}$ & $\begin{array}{c}\text { Viabilidade } \\
(\%)\end{array}$ \\
\hline $1: 50$ & $1,10 \times 10^{5}$ a & $0,89 \times 10^{5}$ a & $81,40 \mathrm{a}$ \\
$1: 100$ & $1,05 \times 10^{5}$ a & $0,85 \times 10^{5}$ a & $80,68 \mathrm{a}$ \\
$1: 150$ & $1,06 \times 10^{5}$ a & $0,89 \times 10^{5}$ a & 84,03 a \\
\hline
\end{tabular}

Medias seguidas pelas mesmas letras nao diferem significativamente entre $5 i$ pelo teste Tukey - $5 \%$.

As diluiçßes utilizadas, neste estudo, năo diferiram entre si estatisticamente, podendo ser utilizada a diluiçăo de $1: 150$ ou a concentraçăo final de $0,006 \%(p / v)$ de diacetato de fluoresceina (FDA).

BURGER \& HACKETT (1982) demonstraram que a viabilidade dos protoplastos analisada imediatamente apos o isolamento pode, não necessariamente, refletir a capacidade dos protoplastos de sobreviver apos um periodo de tempo em meio de cultura. Estes autores verificaram que uma porcentagem de $20 \%$ de viabilidade dos protoplastos apos 13 dias do isolamento (assegurada pelo FDA) coincidiu com a eficiencia de plaqueamento dos mesmos apos 20 dias de cultivo, isto indica que, o diacetato de fluorescefna um indicador confiavel da viabilidade dos protoplastos. 


\subsection{Cultivo de protoplastos (Experimento 13)}

A concentraça osmótica do meio de cultivo e a densidade de plaqueamento dos protoplastos sao considerados fatores muito importantes na obtençăo de sucesso na cultura de protoplastos (VARDI \& GALUN, 1988).

No presente trabalho, os protoplastos foram inoculados em meios contendo diferentes concentraçoes de sacarose e manitol e nas densidades de $5 \times 10^{4}$ e $10^{5}$ protoplastos/m1 (item 4.10 - Experimento 11). Nä se observou a formação de parede e nem divisá dos protoplastos em nentum dos tratamentos estudados. Apos uma semana de cultivo, os protoplastos estavam en perfeitas condiçós, porém, a partir da segunda semana muitos fragmentos e organelas foram observados no meio de cultura.

Nos meios de cultura com concentraça osmótica $(0,3-0,4 \mathrm{M})$, en qualquer uma das duas densidades estudadas, observou-se que os protoplastos absorveram agua aumentando seu volume (Figura 27 ) e,posteriormente, ocorria o rompimento da membrana plasmática com a liberaçá das organelas no meio de cultura. Nas concentraçoes osmóticas maiores $(0,5-0,7 \mathrm{M})$ e densidade de $10^{5}$ protoplastos/ml foi onde se observou protoplastos com melhor aparencia (Figura 26) ate a segunda semana. Na terceira semana de avaliaça, iniciou-se degeneração dos protoplastos em todos os meios de cultura e densidades de plaqueamento estudados. 
Qutros fatores,além dos citados acima, podem estar influenciando o desenvolvimento dos protoplastos.

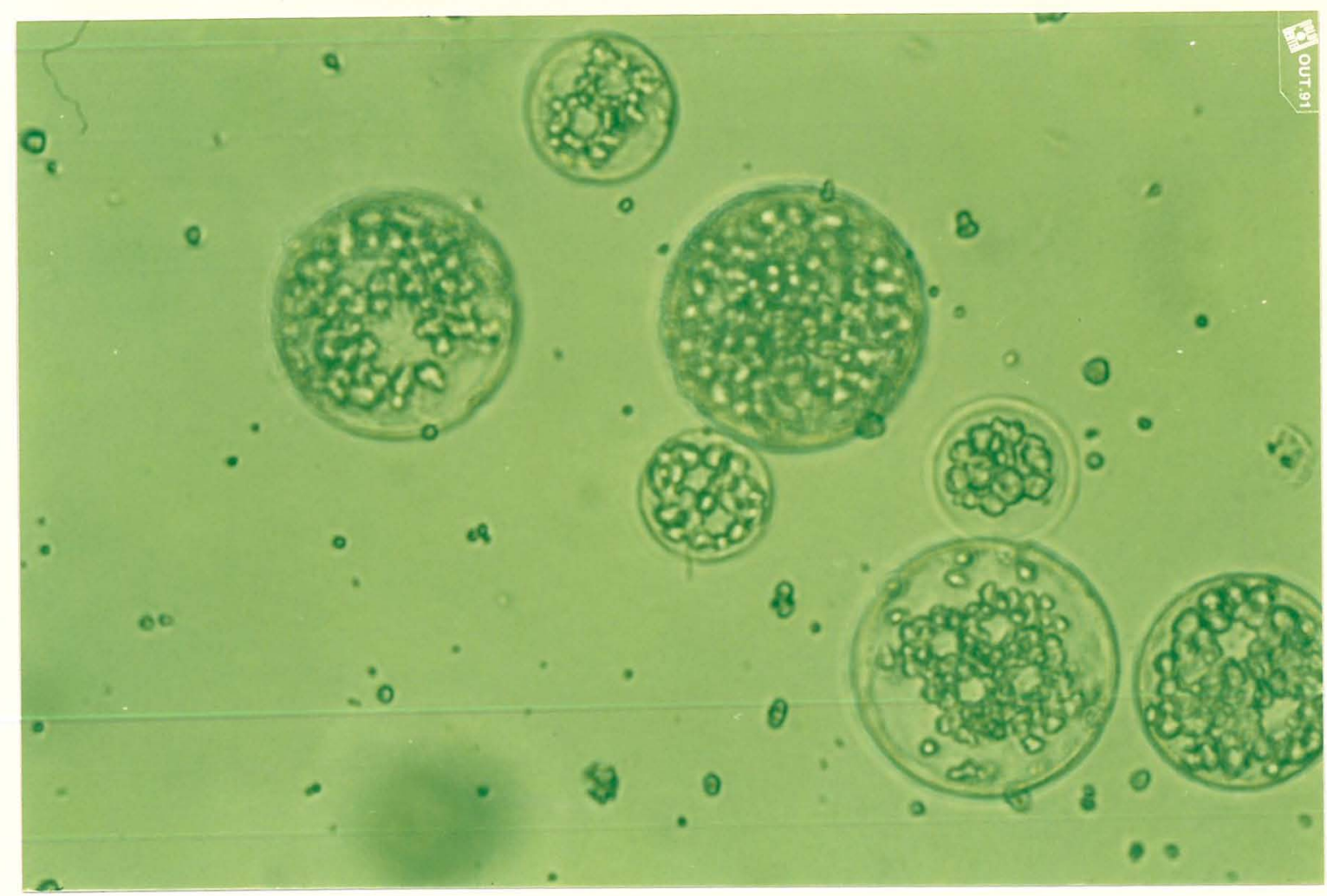

Figura 26. Protoplastos inoculados em meio de cultura contendo $0,45 \mathrm{M}$ de manitol e $0,15 \mathrm{M}$ de sacarose $\mathrm{e}$ densidade de plaqueamento de $10^{5}$ protoplastos $/ \mathrm{ml}$ após 15 dias de cultivo. 


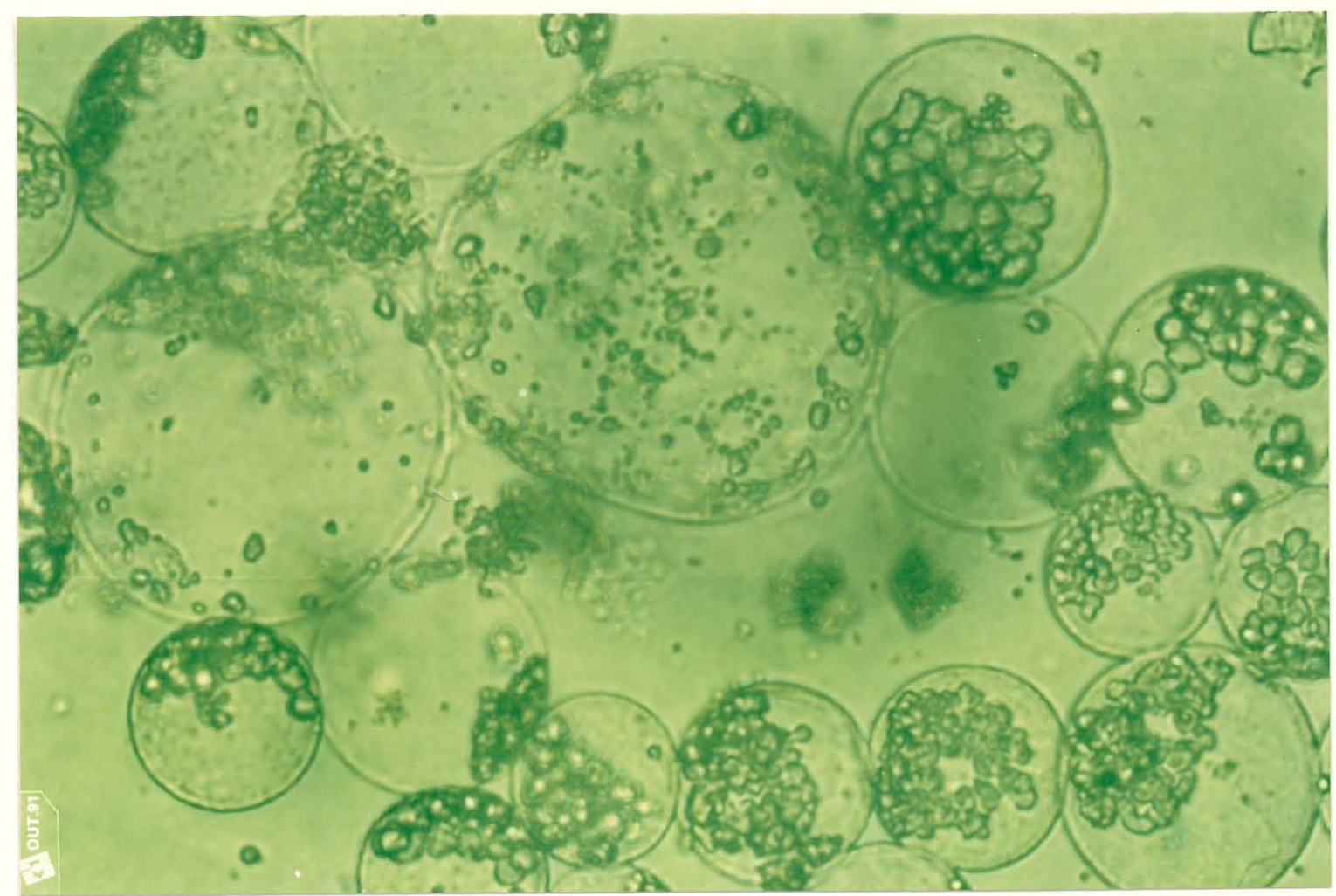

Figura 27. Protoplastos inoculados em meio de cultura contendo 0,25 M de manitol e 0,15 M de sacarose $e$ densidade de $10^{5}$ protoplastos/ml, após 15 dias de cultivo.

A utilização de um gradiente de sacarose-manitol durante o processo de purificaçăo dos protoplastos, tem sido recomendada para a purificação dos protoplastos derivados de calo. Esta técnica está descrita com detalhes nos trabalinos de TUSA et alii (1990) e GROSSER \& GMITTER $(1990)$.

Este processo reduz a quantidade de fragmentos e protoplastos danificados e não viáveis, fatores estes que podem ter um efeito negativo no cultivo dos protoplastos. 
Um meio de cultivo descrito por GROSSER \& GMITTER (1990), bastante rico em nutrientes, foi recomendado para todas as lavagens no processo de purificaça e tambem para o cultivo de protoplastos dos genotipos mais recalcitrantes.

Estudos utilizando a técnica de purificaçăo dos protoplastos com um gradiente de sacarose-manitol e o cultivo dos protoplastos em meio de cultivo mais elaborado podem ser realizados nos protoplastos, obtidos no presente trabalho, no sentido de se obter sucesso na regeneraça da parede celular, divisão celular e regeneração de plantas a partir destes.

4.13. Radiossensitividade dos diferentes materiais

4.13.1. Radiossensitividade do tecido nucelar (Experimento 14)

o efeito da radiaçăo gama sobre a formação de embrioides, a partir de nucelos, e apresentada na Tabela 15. As avaliaçós for am realizadas apos 6 e 8 semanas de cultivo; entretanto, inspeçoses foram realizadas semanalmente na cultura permitindo observar que a radiaçăo aumentou a fase "lag" dos nucelos quanto à formaçăo de embrióides. Na tes- 
temunha iniciou-se formaça de embriobides apos a terceira e quarta semanas de cultivo, enquanto os nucelos irradiados comecaram a formar embriódes a partir da sexta semana de cultivo quando foi realizada a primeira avaliaça. Após oito s emanas de cultivo, nao se observou diferença nas porcentagens de nucelos responsivos nas doses de 20 a 80 Gy. As doses de 20 e 40 Gy formaram praticamente o mesmo número de embribides por nucelo responsivo. As doses acima de 100 Gy foram letais, não se observando a formaçăo de embribides nestes tratamentos. Este efeito tambem foi observado no trabaltho realizado por SPIEGEL-ROY \& KOCHBA (1977a).

SEgundo SPIEGEL-ROY \& KOCHBA (1977a), OS nUcelos são muito sensiveis a irradiação. Entretanto, estes autores verificaram que as doses de 5 e 10 Gy promoveram um estimulo na embriogenese neste tecido. Este efeito nă foi observado no trabalho realizado por PASQUAL (1985) que utilizou as mesmas doses do trabalho dos autores citados acima, no cv. Valencia.

No presente trabalho, os nucelos foram irradiados juntamente com o meio de cultura, onde foram mantioos durante o periodo de cultivo, baseando-se no trabalho de PASGUAL (1985), que não verificou efeito prejudicial aos nucelos quando estes e o meio de cultivo foram irradiados em comparação com os resultados obtidos quando somente o nucelo foi irradiado. Esta pratica tambem facilita o processo de tratamento mutagenico em nucelos. 
Tabela 15. Efeito da radiaça gama na formaçăo de embriódes em nucelos. Avaliaçbes realizadas 6 e 8 semanas após o tratamento mutagenico.

\begin{tabular}{|c|c|c|c|c|}
\hline \multirow{2}{*}{$\begin{array}{l}\text { Doses } \\
(G y)\end{array}$} & \multirow{2}{*}{$\begin{array}{l}\text { No de } \\
\text { nucelos } \\
\text { com em- } \\
\text { briódides }\end{array}$} & \multicolumn{2}{|c|}{$\begin{array}{l}\text { Nucelos } \\
\text { responsivos (\%) }\end{array}$} & \multirow{2}{*}{$\begin{array}{l}\text { No medio } \\
\text { de embrió- } \\
\text { des/nucelos } \\
\text { responsivos } \\
\text { ( } \pm S)\end{array}$} \\
\hline & & $\frac{6}{\text { semanas }}$ & $\begin{array}{c}8 \\
\text { semanas }\end{array}$ & \\
\hline 0 & $8(28)$ & 21,41 & 28,57 & $4,25 \pm 2,05$ \\
\hline 20 & $2(28)$ & 7,14 & 7,14 & $6,00 \pm 1,41$ \\
\hline 40 & $2(28)$ & 7,14 & 7,14 & $6,50 \pm 0,70$ \\
\hline 60 & $2(28)$ & 0,00 & 7,14 & $2,00 \pm 0,00$ \\
\hline 80 & $2(28)$ & 3,57 & 7,14 & $3,50 \pm 0,70$ \\
\hline 100 & $0(28)$ & 0,00 & 0,00 & 0,00 \\
\hline 120 & $0(28)$ & 0,00 & 0,00 & 0,00 \\
\hline 140 & $0(28)$ & 0,00 & 0,00 & 0,00 \\
\hline 160 & $0(28)$ & 0,00 & 0,00 & 0,00 \\
\hline
\end{tabular}

Foram utilizados frutos com 12 semanas de idade e em alguns deles se observou que ja havia a existencia de embriódes no estadio globular lem media 3 enbrioides/semente). Estes embribides foram retirados dos nucelos para garantir que os embribides se formariam somente apos o tratamento mutagenico. Talvez, este fato tenha influenciado no potencial de resposta destes nucelos. STARRANTINO \& RUSSO (1976-1977) utilizaram frutos com $100-120$ dias de idade para extração de nucelos. PASQUAL (1985) utilizou 
frutos com 12 semanas de idade do cv. Valencia e GOLDMAN (1988) utilizou frutos com 10-12 semanas de idade no cv. Pera, devido a dificuldade de se extrair nucelos sem danifica-los, de frutos mais jovens. Porem, com o emprego da metodologia de extração, utilizada no presente estudo, talvez seja possivel evitar maiores danos aos nucelos, e sementes de frutos mais jovens possam ser utilizadas.

Verificou-se, no presente estudo, que o aumento das doses de radiacão causou uma redução na porcentagem de enraizamento e um aumento na porcentagem de anormalidades (Tabela 16). Embora a porcentagem de anormalidades năo esteja diferindo entre os tratamentos em que se utilizou a irradiaçăo, verifica-se que as doses acima de 40 Gy causaram uma grande redução no número de embrioides obtidos e no enraizamento destes embribides. Doses de 20 a 40 Gy seriam indicadas para o tratamento mutagenico, levando-se em consideração a necessidade de se aumentar o numero de nucelos a serem tratados.

$$
\text { PASQUAL (1985) recomenda a dose de } 10-20 \text { GY }
$$
para indução de mutaçóes no cv. valencia, aplicada a nucelos por ocasião da inoculaçáo ou uma semana depois. STARRANTINO \& RUSSO (1976-1977) trabalharam com nucElos extraldos de frutos irradiados com as doses 20 e 40 Gy e verificaram que a porcentagem de nucelos responsivos comparada com a testemunta foi praticamente a mesma e era de cerca de $27,5 \%$ dos nucelos cultivados. Provavelmente, a 
irradiaça dos frutos esteja causando menos dano aos nucelos que a irradiaça direta destes explantes.

Tabela 16. Desenvolvimento de embrióides individualizados oriundos de nucelos submetidos a diferentes doses de radiaça gama. Avaliação realizada 60 dias apos a inoculaça dos embrióldes no estadio globular.

\begin{tabular}{ccccc}
\hline $\begin{array}{c}\text { Doses } \\
\text { (Gy) }\end{array}$ & $\begin{array}{c}\text { No de } \\
\text { obtidos }\end{array}$ & $\begin{array}{c}\text { Ralzes } \\
(\%)\end{array}$ & $\begin{array}{c}\text { Anormalidades } \\
(\%)\end{array}$ & $\begin{array}{c}\text { Plantulas } \\
\text { normais } \\
(\%)\end{array}$ \\
\hline 0 & 34 & 58,80 & 76,45 & 23,52 \\
20 & 12 & 41,67 & 83,33 & 16,67 \\
40 & 13 & 38,46 & 34,60 & 15,38 \\
60 & 4 & 0,00 & 100,00 & 0,00 \\
80 & 7 & 18,56 & 85,68 & 14,28 \\
100 & 0 & 28,56 & 85,68 & 0,00 \\
120 & 0 & 0,00 & 0,00 & 0,00 \\
140 & 0 & 0,00 & 0,00 & 0,00 \\
160 & 0 & 0,00 & 0,00 & 0,00 \\
\hline
\end{tabular}




\subsubsection{Radiossentividade em calos nucelares (Experimento 15$)$}

Calos obtidos a partir de nucelos cultivados em meio MT suplementado com BAP $(10 \mathrm{mg} / 1)$ foram utilizados neste experimento. Estes calos, quando mantidos neste mesmo meio de cultivo, se proliferam e nao formam embribides, mantendo assim, uma composição uniforme. Este fato os tornam diferentes daqueles mantidos em meio MT sem reguladores de crescimento, onde embrioides se diferenciam tornando o calo um tecido com composiçăo bastante heterogenea, onde além das células, existem pro-embrioides e embrioides em vários estádios de desenvolvimento, diminuindo a probabilidade de obtenção de mutantes solidos, após tratamento com agentes mutagenicos.

Aposs o tratamento cam diferentes doses de raios gama, os calos foram inoculados em meio MT contendo so g/1 de lactose e $500 \mathrm{mg} / 1$ de EM. Os embribides, assim formados foram transferidos ainda no estadio globular, para meio MT suplementado com $500 \mathrm{mg} / 1$ de EM e $50 \mathrm{~g} / 1$ de sacarose, onde observou-se o desenvolvimento destes embribides. Os embribides que se desenvalveram ate o estadio cotiledonar foram inoculados em meio fresco, contendo a mesma constituição do meio anterior, para germinaça e regeneração de plantas.

A Tabela 17 mostra o efeito de diferentes do- 
ses de radiaço gama no crescimento dos calos e na diferenciaça de embriódes a partir destes, 40 dias após o tratamento mutagenico. Observa-se que o peso mediolcalo diminuiu com o aumento da dose de radiaçá. Na dose de 180 Gy, os calos apresentavam um aspecto necrosado e nao formaram nenhum embrioide. A dose de 150 Gy diminuiu drasticamente o número de embriódes por calo. Verificou-se que o número de embriódes por calo foi maior nas doses de 30 a 120 Gy, embora năo diferissem significativamente da testemunha. A dose de 30 Gy apresentou o maior numero de embribides por calo.

Tabela 17. Efeitos de diferentes doses de radiação gama no crescimento de calos e diferenciação de embrioides a partir destes.Avaliaça 40 dias apos o incicio do cultivo.

\begin{tabular}{lcr}
\hline $\begin{array}{c}\text { Doses } \\
\text { (Gy) }\end{array}$ & $\begin{array}{c}\text { Peso mediolcalo } \\
(\mathrm{mg})\end{array}$ & $\begin{array}{c}\text { Numero medio } \\
\text { de embribes/calo }\end{array}$ \\
\hline 0 & $239,39 \mathrm{a}$ & $935,95 \mathrm{a}$ \\
30 & $207,47 \mathrm{a}$ & $2,551,41 \mathrm{a}$ \\
60 & $151,40 \mathrm{~b}$ & $2.280,63 \mathrm{a}$ \\
90 & $103,93 \mathrm{c}$ & $1.984,75 \mathrm{a}$ \\
120 & $84,27 \mathrm{~cd}$ & $1.002,30 \mathrm{a}$ \\
150 & $44,34 \mathrm{de}$ & $22,11 \mathrm{~b}$ \\
180 & $38,71 \mathrm{e}$ & $0,00 \mathrm{c}$ \\
\hline
\end{tabular}

Medias seguidas de letras iquais nå diferem significativamente entre si pelo teste Tukey - $5 \%$. 
A diminuiça do peso dos calos, com o aumento da dose de radiaça, esta de acordo com o que foi observado por KOCHBA \& SPIEGEL-ROY (1977C). Estes mesmos autores observaram um aumento no número de embriódes/calo a partir da dose de $40 \mathrm{GY}$ ate a dose de $200 \mathrm{GY}$, sendo que o efeito maximo foi conseguido com a dose de $160 \mathrm{~Gy}$, com uma intensidade de 850 Gy/h.

\section{SKoog ${ }^{\circ}$, citado por SPIEGEL-ROY \& KOCHBA} (1973), mostrou que os raio-x inativam auxinas. A diminuiça do peso dos calos tem sido associada à inativaçăo das auxinas endogenas nos calos irradiados. Esta inativaçăo ou reduça dos niveis endógenos de auxinas nos calos irradiados tambem está associada ao aumento do número de embriódes após tratamento mutagenico.

KOCHBA \& SPIEGEL-ROY (1977C) irradiaram calos com diferentes doses ate 300 Gy e, posteriormente, inocularam en meio contendo diferentes concentraçBes de IAA e observaram que certas concentraços de IAA aumentaram a proliferação de embribides nas doses mals altas de radiação. Segundo estes autores, a irradiaça com as mais altas doses, pode ter reduzido o nivel de auxina a um nivel subotimo e a adiçăo de IAA estaria promovendo a embriogenese, em tais condiçoses.

- SKOOG, F. The effect of $x$-irradiation on auxin and plant growth. F. Cell. Compo. Physiol,, 1: 207, 1935. 
Ds embribides, obtidos no presente estudo, foram transferidos para meio básico de cultivo MT, no estadio globular (1-2 mm de diametro). Observaçzes foram realizadas sobre a porcentagem de embribides que se desenvolveram ate o estadio cotiledonar, de embribides que germinaram formando raszes e plantas normais e a porcentagem de anormalidades encontradas nos embribides e plantas. Todos estes resultados estão apresentados nas Tabelas 18 e 19 .

Tabela 18. Desenvolvimento de embribides invidualizados oriundos de calos submetidos a diferentes doses de radiação. Avaliação realizada 30 dias apos a inoculaça dos embribides no estádio globular.

\begin{tabular}{lccc}
\hline $\begin{array}{c}\text { Doses de em } \\
\text { briódes trans } \\
\text { feridos }(1-2 \mathrm{~mm} \phi)\end{array}$ & $\begin{array}{c}\text { Estadio } \\
\text { globular } \\
(\%)\end{array}$ & $\begin{array}{c}\text { Estádio } \\
\text { cotiledonar } \\
(\%)\end{array}$ \\
\hline 0 & 164 & 51,82 & 48,16 \\
30 & 194 & 84,53 & 15,46 \\
60 & 226 & 63,40 & 34,59 \\
90 & 269 & 73,23 & 26,76 \\
120 & 337 & 78,33 & 21,66 \\
150 & 198 & 81,31 & 18,68 \\
180 & 0 & 0 & 0 \\
\hline
\end{tabular}


Tabela 19. Germinaçao de embribides desenvolvidos, oriundos de calos submetidos a diferentes doses de radiação gama. Avaliação realizada 30 dias após a inoculaçao dos embriódes no estadio cotiledonar.

No de

$\begin{array}{cc}\text { Doses } & \text { embrioides } \\ \text { (Gy) } & \text { transferidos } \\ \text { no estadio } & \text { cotiledonar }\end{array}$

$\operatorname{Raiz}$

$(\%)$

Anormalidades

$(\%)$
Plantulas normais

$(\%)$

\begin{tabular}{rcccc}
\hline 0 & 79 & 55,69 & 62,00 & 37,97 \\
30 & 30 & 13,33 & 76,63 & 23,33 \\
60 & 78 & 21,51 & 75,51 & 24,46 \\
90 & 72 & 17,94 & 81,42 & 17,94 \\
120 & 73 & 32,88 & 72,52 & 27,40 \\
150 & 37 & 40,05 & 72,90 & 27,00 \\
180 & 0 & 0 & 0 & 0 \\
\hline
\end{tabular}

Pode-se notar na Tabela 18, que a maior porcentagen $(48,16 \%)$ de embribides, que se desenvolveram ate o estadio cotiledonar, ocorreu na testemunta. A radiaça pode ter afetado a capacidade dos embrioldes de completarem seu desenvolvimento. KOCHBA \& SPIEGEL-ROY (1977c) verificaram que a adição de IAA aos calos irradiados promoveu um melhor desenvolvimento dos embrioides em plantas. possivelmente, no presente trabalho, a irradiaçao tenta causado uma reduçáo no nivel de IAA causando assim uma reduça na capacidade de desenvolvimento destes embribides. 
A porcentagem de enraizamento tambem sofreu uma reducão com a radiaçă, assim como a porcentagem de plantulas normais, como se observa na Tabela 19. Anormalidades são frequentemente observadas nos embribides obtidos de cultura de nucelos e calos (GMITTER \& MOORE, 1986), sem tratamento mutagenico. Segundo estes autores, a porcentagem de embrioides que apresentam capacidade de desenvolverem plantas adultas pode variar de acordo com o cultivar estudado; para o cV. Hamlin ( $C$. sinensis) eles encontraram o valor de $35 \%$ de embrioides que se desenvolveram ate estadios mais avançados e destes $48 \%$ germinaram. Encontrou-se, no presente estudo, uma porcentagem de $37,97 \%$ de embriódes, que ja haviam atingido o estadio maduro lcotiledonar expandidoj e se desenvolveram em plantulas, na testemunha. Alguns embrioides formaram ralzes mas não desenvolveram a parte aerea da planta. Anormalidades tais como cotiledones multiplos, fundidos e fasciados foram encontrados. Alguns embrioides desenvolveram parte aerea anormal com epicotilo fasciado ou gemas apicais multiplas.

As anormalidades foram observadas em todas as doses de radiaçá estudadas. As doses de 30 a 150 Gy apresentaram porcentagens de plantas anormais bastante semeIhantes conforme os resultados apresentados na Tabela 19.

KOCHBA et alii (1982) utilizaram doses
de 80,120 e 160 Gy a uma taxa de dose de 800 Gy/h e verificaram que estas doses aceleraram o processo de seleça 
en calos embriogenicos do cV. Shamouti para salinidade. A dose de 120 Gy produziu o melhor resultado quando se utilizou $10 \mathrm{~g} / 1$ de $\mathrm{NaCl}$ no meio de cultura.

No presente estudo, verificou-se que a dose de 120 Gy produziu um número medio de embrioides $(1.002,30)$ que năo diferiu estatisticamente do valor obtido na testemuntia. A dose de 150 Gy produziu uma reduçăo drástica no número médio de embrioides formados por calo $(22,11)$. Este fato deve ser considerado, pois uma dose que cause tal reduç̃o nă e conveniente; muitas mutaçชes induzidas nas celulas dos calos podem ser perdidas, se estas celulas nă tiverem capacidade de formar embribides. Assim sendo, a dose de 120 Gy pode ser recomendada para a indução de mutaçốs em calos embriogénicos de citros.

4.13.3. Radiossensitividade em protoplastos (Experimento 16$)$

A Tabela 20 mostra os resultados obtidos apos a exposiçáo dos protoplastos a diferentes doses de radiaça $9 a m a$.

A Figura 28 mostra a curva de sobrevivéncia dos protoplastos do CV. Pera (C. sinensis), em relaça a testemuntia. Os protoplastos foram expostos a radiaçáo imediatamente apos o isolamento. A sobrevivencia e expressa como a porcentagem de protoplastos viaveis atraves do 
uso de diacetato de fluoresceina, apos 24 horas do tratamento mutagenico.

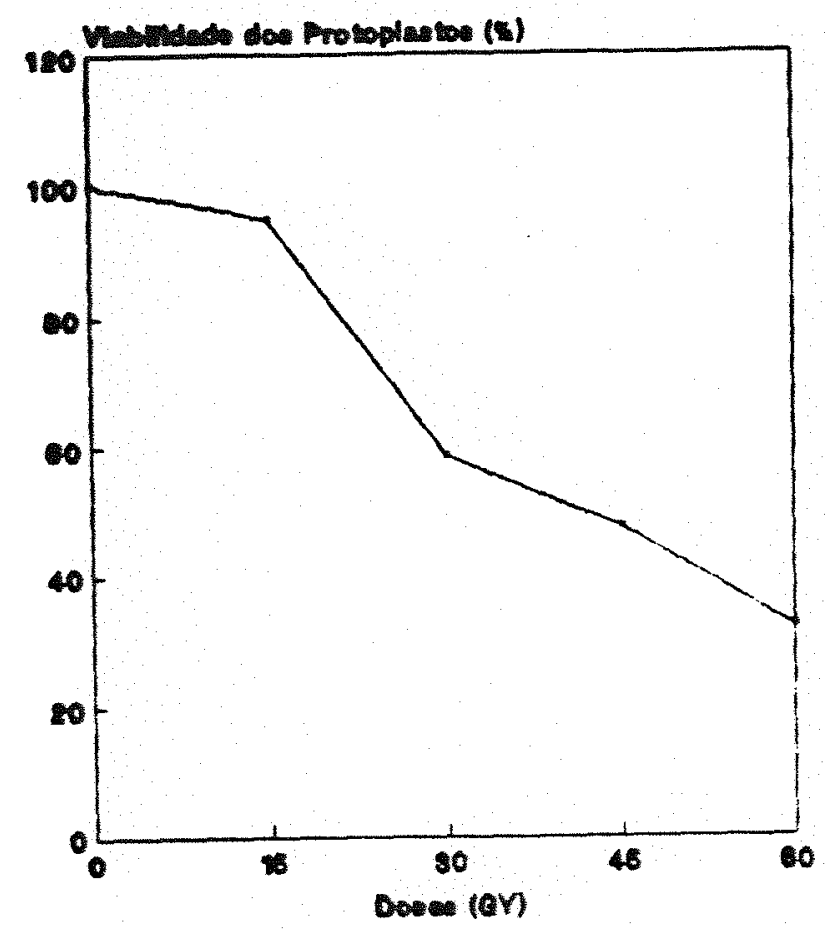

Figura 28. Representação grafica da porcentagem de viabilidade de protoplastos em diferentes doses de radiação gama, em relação à testemuntia

- valor da LDso (dose que causa $50 \%$ de letalidade) nas condiçoes em que o experimento foi realizado, situa-se ao redor de 41 Gy. Esta dose e maior que os valores de 34 e 37,5 Gy encontrados por VARDI et alil (1975) para o cV. Shamouti e GOLDMAN (1988) para o cV. Pera, respectivamente. Estas diferencas podem ser explicadas, tal- 
vez, devido as diferentes metodologias utilizadas nestes trabalhos. Neste estudo, os protoplastos foram irradiados logo em seguida ao isolamento, enquanto VARDI et alii (1975) e GOLDMAN (1988) o fizeram 42 horas apos o isolamento. Segundo GALUN \& RAVEH (1975) que trabalharam com protoplastos de Nicotiana, ocorre um aumento abrupto na radiossensitividade em protoplastos irradiados apos un ou dois dias do isolamento, em relaçăo ao tratamento mutagenico realizado logo após o isolamento.

Tabela 20. Viabilidade dos protoplastos submetidos a diferentes doses de radiação gama.

\begin{tabular}{lccc}
\hline $\begin{array}{c}\text { Doses } \\
\text { (Gy) }\end{array}$ & Sem & $\begin{array}{c}\text { Com } \\
\text { fluorescencia }\end{array}$ & Viabilidade \\
\hline 0 & $10,32 \times 10^{4} \mathrm{a}$ & $6,35 \times 10^{4} \mathrm{a}$ & $(\%)$ \\
15 & $10,04 \times 10^{4} \mathrm{a}$ & $5,96 \times 10^{4} \mathrm{ab}$ & 64,80 \\
30 & $10,18 \times 10^{*} \mathrm{a}$ & $3,92 \times 10^{4} \mathrm{ab}$ & 61,48 \\
45 & $10,62 \times 10^{4} \mathrm{a}$ & $3,36 \times 10^{4} \mathrm{ab}$ & 38,00 \\
60 & $10,14 \times 10^{4} \mathrm{a}$ & $2,08 \times 10^{4} \mathrm{~b}$ & 30,82 \\
\hline
\end{tabular}

Medias sequidas das mesmas letras não diferem significativamente entre $5 i$ pelo teste Tukey - $5 \%$. 
GOLDMAN (1988) tambem observou, em seu trabaIho, uma diminuiçăo na sensitividade dos protoplastos em todas as doses utilizadas em relaça ao trabal ho de VARDI et alii (1975). Talvez, este fato esteja relacionado com o genótipo da planta estudada, uma vez que o genotipo e um dos fatores que influenciam na sensitividade a irradiaçăo.

No trabalio realizado por VARDI et alii (1975), os protoplastos foram irradiados juntamente com o meio de cultura e ali mantidos durante todo o tempo de cultivo. A avaliação foi realizada apos 4 semanas de cultivo fazendo-se a contagem do número de colonias de celulas formadas. GOLDMAN (1988) utilizou o corante azul de metileno para avaliar a viabilidade dos protoplastos, 24 horas após o tratamento mutagenico, estabeleceu a porcentagem de sobrevivencia em relação à testemuntia.

Apesar das diferentes metodologias empregadas, constatou-se que as respostas à irradiação for am bastantes proximas, embora, uma pequena reduçao na radiossensitividade tivesse sido observada, no presente estudo, quando se faz uma comparaçăo com os trabalhos realizados por VARDI et alii (1975) e GOLDMAN (1988).

E possivel, então, realizar o tratamento mutagenico e imediatamente apos a irradiaça utilizar o corante diacetado de fluorescesna para estudar a viabilidade dos mesmos. 


\subsubsection{Radiossensitividade en cot1ledones de embribes nucelares (Experimento 17)}

A Tabela 21 apresenta a porcentagem de explantes responsivos e número medio de brotaçes por explante responsivo em cotiledones de embribes nucelares expostos a diferentes doses de radiação gama.

Tabela 21. Efeito de diferentes doses de radiaçăo gama na formaça de brotaçōes adventicias em cotiledones de embrizes nucelares. Avaliaçă 90 dias após 0 tratamento mutagénico.

\begin{tabular}{|c|c|c|c|}
\hline \multirow{2}{*}{$\begin{array}{l}\text { Doses } \\
(G y)\end{array}$} & \multicolumn{2}{|c|}{$\begin{array}{c}\text { Explantes responsivos } \\
(\%)\end{array}$} & \multirow{2}{*}{$\begin{array}{c}\text { No medio de brotaços } \\
\text { explante responsivo } \\
( \pm S)\end{array}$} \\
\hline & observada & $\begin{array}{l}\text { en relaçă ao } \\
\text { controle }=100\end{array}$ & \\
\hline 0 & 55 & 100,0 & $8,78 \pm 3,84$ \\
\hline 10 & 55 & 100,0 & $10,10 \pm 2,83$ \\
\hline 20 & 50 & 90,9 & $8,86 \pm 4,33$ \\
\hline 30 & 50 & 90,9 & $5,96 \pm 4,52$ \\
\hline 40 & 45 & 81,8 & $8,50 \pm 3,53$ \\
\hline 50 & 30 & 54,6 & $5,00+1,22$ \\
\hline 60 & 10 & 18,2 & $0,60 \pm 0,89$ \\
\hline 70 & 10 & 18,2 & $0,60 \pm 0,89$ \\
\hline 80 & 5 & 9,1 & $1,00 \pm 2,23$ \\
\hline 90 & 5 & 9,1 & $0,40 \pm 0,89$ \\
\hline
\end{tabular}


A dose de so Gy provocou uma redução na porcentagem de explantes responsivos, em relaçao ao controle $(54,59 \%)$ e no número medio de brotaçbes/explante responsivo, em relaça as doses menores que 50 Gy, utilizadas no presente estudo. Alem disto, năo produziu uma grande reduçăo na formaçăo de brotaçós, como se observou nas doses maiores. Por esta razao, pode-se recomendar esta dose na induçăo de mutaçbes a partir de gemas adventicias, obtidas. em cotiledones de embrizes nucelares.

o interesse nas brotaçoes adventicias como um meio de produzir mutantes solidos, isto e, sem quimerismo, em partes irradiadas de uma planta, comecou com experimentos em Saintpaulia. Folhas destacadas de vários cultivares de violeta africana foram irradiadas e, após o enraizamento e subsequente produção de plantulas adventicias in vivo, observou-se a produção de plantas completamente normais e de mutantes não quimericos. Segundo BROERTJES \& VAN HARTEN (1988), a explicação para o aparecimento de uma grande porcentagem de plantas năo quimericas, se deve ao fato de que a nova brotaça pode ter se originado de uma unica celula da epiderme.

No presente estudo, verificou-se (item 4.9) que as gemas neoformadas são exogenas na origem, isto e, tem origem nas camadas epidermica e subepidermicas dos cotiledones. Năo foi possivel evidenciar se as brotaçães tiveram origem unicelular ou multicelular. 
Entretanto, existem varias formas de se evitar a formação de quimeras mesmo nas situaçzes en que as gemas se formam a partir de mais de uma celula (BROERTJES \& VAN HARTEN, 1988 ).

VENVERLOO et alii (1983) colocaram que mesmo se a area apical de uma gema adventicia for formada por células descendentes de mais de uma célula epidermica, - resultado final pode ser comparavel a situaçăo com uma única celula. Isto porque, se o ápice é um sistema dinamico, muitas células do domo apical podem deixar o apice e se incorporar nas fol has e ramos. Entao, o apice por si so pode, finalmente, consistir indiretamente de celulas descendentes de uma única celula epidermica. Podendo-se desta forma, dar origem a um mutante solido apos tratamento mutagênico.

4.14. Consideraçós gerais e perspectivas futuras

Os estudos realizados no presente trabaliho, tinham como objetivo adaptar diferentes metodologias de cultura de tecidos para o cv. Pera (Citrus sinensis L. osbeck), visando,principalmente, a aplicaçao destas tecnicas em trabal hos com indução de mutaçres. 
A embriogenese somatica em citros ocorre via direta e indireta $e$ os embrioides tem origem unicelular (BUTTON et alii, 1974, KOBAYASHI et alii, 1981). Portanto, nucelos e calos embriogenicos constituem-se em materiais adequados para se evitar a ocorrencia de quimerismo, após o tratamento mutagenico. Protoplastos tambem constituem-se em excelentes materiais para se trabalhar com induçao de mutaçóes pois sao celulas isoladas com maior homogeneidade de penetração do agente mutagenico e do agente seletivo, no caso de se estar trabalhando com seleçăo in vitro.

A obtenção de calos com rápida formaçăo, proliferaçăo e grande potencial embriogenico, é, entzo, o ponto de partida para a aplicação de diferentes tecnicas que podem auxiliar no melhoramento das especies eltricas.

No presente trabalio, obteve-se a formaça e proliferação de calos nucelares, mais rapidamente, em meio basico MT suplementado com $10 \mathrm{mg} / 1$ de BAP e $500 \mathrm{mg} / \mathrm{l}$ de EM (Experimento 2). Estes calos apresentavam uma composição bastante homogenea (Figura 4), pois nao se observa a formação de embribides quando mantidos neste mesmo meio de cultivo, notando-se apenas a proliferação de calos. Este é um aspecto bastante importante a ser considerado em trabaIhos com indução de mutaçoes e isolamento de protoplastos a partir de calos nucelares.

Os calos nucelares, obtidos no meio MT sem reguladores de crescimento (Experimento 2), apresentavam um 
crescimento lento e uma composicăo bastante heterogenea, isto e, alem da proliferaça de calos, observava-se embrioides em diferentes estadios de desenvolvimento tornandose diffcil a separação de calos e embribides. Quando estes calos foram transferidos para diferentes meios de cultura (Experimento 5) o número de embribides/calo diminuiu em alguns tratamentos e verificou-se que o meio com $1,0 \mathrm{mg} / 1$ de CIN e $0,1 \mathrm{mg} / 1$ de IAA favoreceu a proliferaçăo de calos, embora, houvesse uma pequena proliferaça de embrioides nestes calos. Foi verificado, tambem, que este meio de cultura produziu o maior efeito na habituaçăo dos calos embriogenicos (experimento 6). Portanto, estes calos constituemse tambem, em um bom material para se trabalhar com indução de mutaçóses e isolamento de protoplastos.

- meio suplementado com BAP $(10 \mathrm{mg} / 1)$ também resultou na habituação dos calos. A habituação e considerada uma caracteristica importante em calos que vao dar origem a protoplastos, pois segundo GROSSER \& GMITTER (1990), a divisão dos protoplastos so foi observada em protoplastos obtidos a partir de calos embriogenicos habituados. Os calos, obtidos neste meio de cultura,foram transferidos para meio suplementado com lactose $50 \mathrm{~g} / 1$ e $500 \mathrm{~g} / 1 \mathrm{de}$ EM (Experimento 3 ), onde se observou a grande capacidade embriogenica destes calos.

Parte dos embribides, obtidos neste meio de cultura,desenvolveram-se em plantas (Experimento 4), sendo 
que o meio suplementado com $1,0 \mathrm{mg} / 1$ de CIN e $0,1 \mathrm{mg} / 1$ de IAA favoreceu a formaça de parte aerea e raiz. Observou-se - desenvolvimento anormal de varios embribides formando cotiledones fundidos, múltiplos e fasciados.

Anormalidades na morfologia externa dos embribides têm sido constantemente relatadas tambem para outras especies de plantas (AMMIRATO, 1985).

Como foi observado no Experimento 15 , dos embrizes inoculados no estadio globular $(1-2 \mathrm{~mm}$ de diametro), $52 \%$ permaneceram neste estadio e nao se desenvolveram em estadio maduro, a partir do qual ocorre a germinaçáo a a regeneração de plantas. Estudos devem ser realizados no sentido de aumentar a porcentagem de embribides globulares que conseguem atingir estadios mais avangados de desenvolvimento. As anormalidades observadas em cotiledones e plântulas e as porcentagens de plantulas normais foram bastante semelhantes, tanto na embriogenese diretamente a partir dos nucelos como na embriogenese indireta.

Dando prosseguimento aos trabalios, protoplastos foram isolados de calos nucelares obtidos em meio com BAP. O rendimento obtido no isolamento dos protoplastos foi de $1,03 \times 10^{\circ}$ protoplastos/grama de calo e a viabilidade dos mesmos foi de $84 \%$. Estes valores estão de acordo com aqueles encontrados na literatura (GOLDMAN, 1988 e HIDAKA \& KAJIURA, 1988). Futuros trabal hos devem ser concentrados na obtençăo de um meio de cultura e condiçós de 
cultivo que favoreçam a divisao e regeneraçao de plantas a partir de protoplastos, pois, no presente trabalho, nao se obteve sucesso nesta etapa, nas condiçes em que o cultivo de protoplastos foi realizado.

A importancia dos protoplastos para estudos geneticos e de melhoramento das especies cltricas tem sido amplamente destacada na literatura (VARDI \& GALUN, 1988; GROSSER \& GMITTER, 1990; TUSA et alii, 1990). Além dos vários hibridos somáticos ja conseguidos (GROSSER \& GMITTER, 1990) através da fusão de protoplastos, em estudos mais recentes, obteve-se a regeneraçăo de plantas transgenicas a partir da transformação direta dos protoplastos (VARDI et alii, 1990). Dutra tecnica,utilizada com sucesso em protoplastos de citros, a obtenção de cibridos (VARDI et alii, 1987). Os cibridos tém vantagens sobre os hibridos somaticos, pois năo săo tetraplóides e podem ser utilizados em cruzamentos com outros cultivares e especies em um programa de mel horamento.

Ds estudos realizados sobre a radiossensitividade dos diferentes materiais, no presente trabalho, permitiram obter doses recomendaveis a serem utilizadas em futuros trabalhos, aliando as tecnicas de induçå de mutaçoses e seleção in vitro, por exemplo. A obtençao de plantulas resistentes a salinidade em cultura de calos em citros por BEN-HAYYIN \& GOFFER (1989) estimula o emprego da tecnica de seleção in vitro para a seleça de outras carac- 
teristicas possiveis de serem selecionadas por este processo. D tratamento mutagenico seria utilizado para aumentar a frequencia das mutaçoses para as caracteristicas desejadas.

No presente estudo, tambem se verificou a possibilidade de obtençăo de brotaçbes adventicias a partir de cotiledones de embrizes nucelares. 0 meio de cultura suplementado com $0,5 \mathrm{mg} / 1$ de $B A P$ e $1,0 \mathrm{mg} / 1$ de $\mathrm{NAA}$ foi 0 que apresentou melhores resultados quanto a induçao de brotaçZ̃es e os meios suplementados com $3,0 \mathrm{mg} / 1$ de BAP e $2,0 \mathrm{mg} / 1$ de NAA foram os que apresentaram melnores resultados na multiplicaçăo e enraizamento das brotaçós, respectivamente. Esta tecrica se constitui em uma forma adequada para a micropropagação de plantas, pois a formação da brotaçăes ocorre diretamente do explante e,provavelmente, e mantida a fidelidade genetica. GROSSER \& GMITTER (1990) descreveram uma tecnica semelhante a esta a partir de embribides obtidos de hibridaçăo somatica e que não se desenvolveram em plantas. Tais embriódes foram divididos em partes e inoculados em meio de cultura contendo $2,5-5,0 \mathrm{mg} / 1$ de BAP. Este processo garantiu a formação de inumeras plantas a partir dos embrioides provenientes da fusao de protoplastos.

A tecrica de obtenção de brotaçôs adventicias constitui-se num material com grande potencial para se trabalhar com induçăo de mutaç̧es, pois o tratamento muta- 
genico, antes da indução da formação das gemas, pode resultar em plantas que nao apresentam quimerismo. 


\section{CONCLUSOES}

Os resultados obtidos nas condiçres em que foi realizado o presente trabalino permitem as seguintes conclusbes:

a) Foi possivel obter calos embriogenicos diretamente dos nucelos cerca de 60 dias apos a inoculação dos mesmos em meio basico MT suplementado com BAP ( $10 \mathrm{mg} / 1$ );

b) Os calos cultivados en meio de cultura MT suplementado com $1,0 \mathrm{mg} / 1$ de CIN e $0,1 \mathrm{mg} / 1$ de IAA; $0,1 \mathrm{mg} / 1$ de CINe $0,5 \mathrm{mg} / \mathrm{I}$ de IAA e $10 \mathrm{mg} / \mathrm{l}$ de BAP, tornaram-se habituados.

c) A adição de IAA ao meio de cultura diminuiu o número de embrioldes por nucelos, porém năo suprimiu totalmente o aparecimento destes; 
d) A CIN (1,0 mg/1) foi benefica a formaça de embribides a partir dos nucelos;

e) A adição de lactose $(50 \mathrm{~g} / 1)$ e EM $(500$ mg/1) en meio básico 'MT promoveu sensivelmente a embriogenese em calos nucelares;

f) Embrióides inoculados em meio básico MT contendo $1,0 \mathrm{mg} / 1$ de CIN e $0,1 \mathrm{mg} / 1$ de IAA apresentaram 0 melhor desenvolvimento, atingindo o estadio de plantula;

g) Gemas adventicias foram induzidas em meio MT contendo diferentes concentraçaes de NAA e BAP, porem, as melhores concentraçäes foram $0,5 \mathrm{mg} / 1$ de $B A P$ e $1,0 \mathrm{mg} / 1$ de NAA;

n) Todas as concentraçBes de BAP promoveram a multiplicaçăo das brotaçőes adventicias, porem a melhor resposta foi obtida com a concentração de $3 \mathrm{mg} / 1$ deste hormonio. O enraizamento das brotaçaes so foi observado nas maiores concentraçoes de NAA estudadas ou nos meios contendo NAA E IBA, porem a melhor resposta foi observada com a concentração de $2 \mathrm{mg} / 1$ de NAA;

i) Os cortes histologicos demonstraram que a neoformação de gemas ocorreu a partir de estruturas meris- 
tematicas formadas nas camadas epidermica e subepidermicas năo havendo a formaçăo de calo;

j) o estudo realizado com diacetato de fluoresceina revelou que a diluiçăo de $1: 150$ do corante pode ser utilizada no estudo da viabilidade dos protoplastos de Citrus;

k) As doses de radiaça gama recomendadas para os diferentes materiais podem ser: 20-40 Gy para nuce105, 110-130 Gy para calos nucelares, 35-45 Gy para protoplastos e 40-60 Gy para brotaçbes adventicias, a uma taxa de dose de 970 Gy/h, exceto para protoplastos onde se utilizou 290 Gy/h. 


\section{REFERÊNCIAS BIBLIOGRÁFICAS}

AMMIRATO, P.V. Patterns of development in culture. In: HENKE, R.R.; HOGHES, K.W.; CONSTANTIN, M.P., ed. TisSUE culture in forestry and agriculture, New York, Plenum, 1985. p. $9-29$.

BARRET, H.C. \& RHODES, A.M. A numerical taxonomic study of affinity relationships in cultivated citrus and its close relatives. Systematic Botany, Oxford, $105-36,1976$.

BEN-HAYYIN, G. \& GOFFER, Y. Plantlet regeneration from a $\mathrm{NaCl}$ - selected salt-tolerant callus culture of Shamouti orange (Citrus sinensis L. Osbeck.). PIant Cell Report, Heidelberg, $7: 680-3,1989$.

BENN-HAYYIN, G. \& NEUMANN, H. Stimulatory effect of glycerol. Zeitschrift fuer Pflanzenphysiologie, Stuttgart, $110: 331-7,1983$.

BITTERS, W.P.; MURASHIGE, T.; RANGAN, T.S.; NAUER, E. Investigations on established virus-free citrus plants through tissue culture. California Citrus Nurseremen's Society, Los Angeles, 9: 27-30, 1970 . 
BRoERTJEs, C. \& VAN HARTEN, A.M. "Citrus". In:

ed. Applied mutation breeding for vegetatively propagated crops. Amsterdam, Elsevier, 1988. $279 \mathrm{p}$.

BURGER, D.W. HACKETT, W.P. Regeneration of buds and roots from several citrus tissues. Proceedings of International Society of Citriculture, $161-6,1981$.

BURGER, D.W. \& HACKETT, W.P. The isolation, culture and division of protopolasts from citrus cotyledons (Citrus sinensis). Physiologia Plantarum, Copenhagen, 56: 324-8, 1982 .

BURGER, D.W. \& HACKETT, W.P. Gradients of adventicious bud formation on excised epicotyl and root section of citrus. HortScience, Alexandria, 43: 229-32, 1986.

BUTTON, J. \& BORNMAN, C.H. Development of nucellar plants from unpollinated and unfertilised ovules of the washington navel orange in vitro. Journal of South African Botany, Claremont, 37: 127-34, 1971 .

BUTTON, J. \& BOTHA, C.E.J. Enzymic maceration of Citrus callus and regeneration of plants from single cells. Journal of Experimental Botany, Oxon, 26: 723-9, 1975.

BUTTON, J. \& KOCHBA, J. Tissue culture in the citrus industry. In: REINERT, J. \& BAJAN, Y.P.S., ed. Applied and fundamental aspects of plant cell, tissue and organ culture. Berlin, Springer-verlag, 1977. p.70-92. 
BUTTON, J.; KOCHBA, J.; BORNMAN, C.H. Fine structure of embryoid development from embryogenic ovular callus of "Shamouti" orange (Citrus sinensis Osb.). Journal of Experimental Botany, Oxon, 25(85): 446-7, 1974 .

CAMERON, J.W. \& FROST, H.B. Genetics, breeding, and nucellar emoriony. In: REUTHER, W.; BATCHLOR, L.D.; WEBBER, H.J., ed. The citrus industry. Berkeley, University of California Press, 1968. p.325-70.

CARNEIRO, V.T.C. \& CONROI, T. Protoplastos de celulas vegetais. In: TORRES, A.C. \& CALDAS, L.S., ed. Técnicas e aplicaçôes da cultura de tecidos de plantas. Brasflia, ABCTP; EMBRAPA/CNPH, 1990. P.171-202.

CHATURVEDI, H.C. \& MITRA, G.C. Clonal propagation of citrus from somatic callus culture. Hortscience, Alexandria, $9(2): 118-20,1974$.

CHATURVEDI, H.C. \& MITRA, G.C. Shift in morphogenetic pattern in Citrus callus tissue during prolonged culture. Annal of Botany, London, 39: $671-2,1975$.

CONSTANTIN, M.J. Potential of in vitro mutation breeding for the improvement of vegetatively propagated crop plants. In: INTERNATIONAL ATOMIC ENERGY AGENGY. Induced mutations for crop improvement in Latin America, Vienna, 1984. P. $59-77$.

DURAN-VILA, N.; ORTEGA, V.; NAVARRO, L. Morphogenesis and tissue culture of three citrus species. Plant Cell, Tissue and Organ Culture, Dordrecht, 16: 123-33, 1989. 
EDRISS, M.H. \& BURGER, 0.W. "In vitro" propagation of "Troyer" citrange from epicotyl segments. Scientia Horticulturae, Amsterdam, 23: 162-9, 1984.

ERIKSON, T.R. Protoplast isolation and culture. In: FOWLE, L.C. \& CONSTABEL, F., ed. Plant protoplasts, Florida, CRC Presss, 1985. p.1-20.

EXPORTAÇES agroindustriais. Suma Agricola, Sao Paulo, v: 5-6, mar., 1991.

FAO QUARTERLY BULLETIN OF STATISTICS, ROME, 2: 1990.

FROST, H.B. \& SOOST, R.K. Seed reproduction: development of gametes and embryos. In: REUTHER; W.; BATCHELOR, L.D.; WEBBER, H.J., ed. The citrus industry. Berkeley, University of California Press, 1968. v.2. p.290-324.

GALUN, E. \& RAVEH, D. In vitro culture of tobacco protoplasts: survival of haploid and diploid protoplasts exposed to $x$-ray radiation at different times after isolation. Radiation Botany, Oxford, 15: 79-82, 1975.

GIAGOMETTI, D.C. Taxonomia e nomenclatura dos citros. In: RODRIGUEZ, O. \& VIEGAS, F.C.P., ed. Citricultura brasileira. Campinas, Fundaça Cargill, 1980. p.185-94.

GMITTER, F.G. \& MOORE, G.A. Plant regeneration from underveloped ovules and embryogenic calli of Citrus: embryo production, germination, and plant survival. Plant Cell, Tissue and Organ Culture, Dordrecht, 6: 139-47, 1986. 
GOLDMAN, M.H.S. Cultura de tecidos nucelares, isolamento e radiossentividade de protoplastos de Citrus sinensis (L.) Osbeck cv. Pera. Piracicaba, 1988. 127p. (M.S. - Escola Superior de Agricultura "Luiz de Queiroz"/USP).

GRATTAPAGLIA, D. \& MACHADO, M.A. Micropropagaçao. In: TORRES, A.C. e CALDAS, L.S., eds. Tecnicas e aplicagóes da cultura de tecidos de plantas. Brasilia, ABCTP, EMBRAPA/CNPH, 1990. p.99-171.

GREVE, A. Formaçao da muda citrica. In: MENTEN, J.o.M.; DOURADO NETO, D.; TORRADO, P.V., ed. Curso intensivo de citricultura. Piracicaba, A.E.C. Ceres; ESALQ, 1991. $p .25-36$.

GRINBLAT, U. Differentiation of citrus stem in vitro. Journal of American Society for Horticultural Science, Alexandria, 97 : 599-603, 1972.

GROSSER, J.W. \& CHANDLER, J.L. Aseptic isolation of leaf protoplasts from Citrus, Poncirus, foncirus $x$ Citrus brids and Severinia for use in somatic hybridization experiments. Scientia Horticulturae, Amsterdam, $31: 253-$ 7. 1987 .

GROSSER, J.W. \& GMITTER, F.G. Somatic hybridization of Citrus with wild relatives for germoplasm enhancement and and cultivar development. Hortscience, Alexandria, $25(2): 147-51,1990$.

GROSSER, J.W.; GMITTER, F.G.; CHANDLER, J.L. Intergeneric somatic hybridization sexually incompatible woody species: Citrus sinensis and Severinia disticha. Theoretical Applied Genetics, Berlin, 75: 397-401, 1988. 
HEARN, C.J. Development of seedless grapefruit cultivars through budwood irradiation. Hortsclence, Alexandria, $20(3): 84,1985$.

HENSZ, R.A. Star Ruby, a new deep-red-fleshed grapefruit variety with distint tree characteristics. Jounal of Rio Grande Vally Horticultural Society, Weslaco, 25: $54-8,1971$.

HENSZ, R.A. Mutation breeding of grapefruit (Citrus paradisi Macf.). In: INTERNATIONAL SYMPOSIUM ON THE CONTRIBUTION OF PLANT MUTATION BREEDING TO CROP IMPROVEMENT, Vienna, 1990. Extended synopses. Vienna, IAEA; Rome, FAO, 1990. P.153-4.

HIDAKA, T. \& KAJIURA, I. Plantlet differentiation from callus protoplasts induced from Citrus embryo. Scientia Horticulturae, Amsterdam, 34: 85-92, 1988.

HOWLAND, G.P. \& HART, R.W. Radiation biologY of cultured plant cells. In: REINART, J. \& BAJAJ, Y.P.S., eds. Applied and fundamental aspects or plant cell, tissue, and culture. Springer-verlag, 1977. p.731-56.

IKEDA, F. \& NISHIDA, T. Studies on the off-polyembriogeny by gamma-ray in polyembrionic citrus. Journal of Japanese Society Horticulturae Science, Kyoto, 46(1): 100-1, 1977.

IWAMASA, M. Study on the sterility in genus Citrus with special reference to the seedless. Bulletin of the Horticultural Research Station of Japan Ser. B, Shizuoka, 6: 1-77, 1966. 
JUAREZ, J.; NAVARRO, L.; GUARDIOLA, J.L. Obtention de plants nucccellaires de divers cultivars de clementiniers au moyen de la culture de nucelle in vitro. Fruits, Paris, $31(12): 751-62,1976$.

KANAI, R. \& EDWARDS, G.E. Purification of enzymatically isolated mesophyll protoplasts from $\mathrm{C}_{3}, \mathrm{C}_{4}$ and crassulacean acid metabolism plants using an aqueous dextranpolyethylene glycol two phase system. Plant Physiology, Rockville, 5e: 484-90, 1973.

KARANARATNE, S.M. \& SCOTT, K.J. Mitotic activity in protoplants isolated from Sorghum bicolor leaves. Plant Science Letters, Limerick, 23: 11, 1981.

KITTO, S.L. \& YOUNG, M.J. In vitro propagation of Carrizo citrange. HortScience, Alexandria, 16(3): 305-6, 1981.

KOBAYASHI, S. Uniformity of plants regenerated from orange (Citrus sinensis Osb.) protoplasts. Theoretical and Applied Genetics, Berlin, 44: 10-14, 1987.

KOBAYASHI, S.; IKEDA, I.; NAKATANI, M. ROle on the primordium cell in nucellar embryogenesis in citrus. Proceedings of the International Citricultura, (1): 44-8, 1981 .

KOBAYASHI, S.; IKEDA, I.; NAKATANI, M. Induetion of nucellar callus from orange (Citrus sinensis osb.) ovules, and uniformity of regenerated plants. Bulletin of the Fruit Tree Research Station, Ser. E, Hiroshima, 5: 4354,1984 . 
KOBAYASHI, S.; IKEDA, I. UCHIMIYA, H. Conditions for high frequency embryogenesis from orange (Citrus sinensis 0sb.) protoplasts. Plant Cell Tissue and Organ Culture, Dordrecht, 4: 149-59, 1985.

KOBAYASHI, S.; UCHIMIYA, H.; IKEDA, I. Plant regeneration from "Trovita" organge protoplasts. Japan Journal of Breeding, Tokyo, $33(2): 119-22,1983$.

KOBAYASHI, S.; OHGAWARA, T.; OHGAWARA, E.; OYAMA, I.; ISHIL, S. A somatic hybrid plant of protoplasts fusion between navel orange (Citrus sinensis) and Satsuma Mandarin (Citrus unstiu). Plant Cell, Tissue and Organ Culture, Dordrecht, $5: 63-9,1988$.

KOCHBA, J. \& BUTTON, J. The stimulation of embryogenesis and embryoid development in habituated ovular callus from the "Shamouti" orange (Citrus sinensis) as affected by tissue age and sucrose concentration. Zeitschrift fur Pflanzenphysiologie, stuttgart, 73: 415-21, 1974.

KOCHBA, J. \& SPIEGEL-ROY, P. Effect of culture media on embryoid formation from ovular callus of "Shamouti" orange (Citrus sinensis). Journal of Plant Breeding, Berlin, 69: $156-62,1973$.

KOCHBA, J. \& SPIEGEL-ROY, P. Cells and tissue culture for breeding and developmental studies of citrus. HortScience, Alexandria, 12: 110-4, 1977a. 
KOCHBA, J. \& SPIEGEL-ROY, P. The effect of auxins, cytokinins and inhibitors on embryogenesis in habituated ovular callus of the "Shamouti: orange (Citrus sinensis). Zeitschrift fuer Pflanzenphysiologie, stuttgart, 81 : 283-8, 1977 b.

KOCHBA, J. \& SPIEGEL-ROY, P. Embryogenesis in gamma-irradiated habituated ovular callus of the "Shamouti" orange as affected by auxin and by tissue age. Envirommental and Experimental Botany, Oxford, 17: 1519, $1977 \mathrm{C}$.

KOCHBA, J.; SPIEGEL-ROY, J.; SAFRAN, H. Adventive plants from ovules and ovule - parts in Citrus. Planta, Heidelberger, $106: 237-45,1972$.

KOCHBA, J.; SPIEGEL-ROY, P.; NEUMANN, N.; SAAD, S. StIMUlation of embryogenesis in citrus ovular callus by $A B A$, ethephon, $C C C$ and $a l a r$ and its suppression by GAs. Zeitschrift fuer Pflanzenphysiologie, Stuttgart, 89: 427$32,1978$.

KOCHBA, J.; SPIEGEL-ROY, P: NEUMANN, H.; SAAD, S. Effect of carbohydrates on somatic embryogenesis in subcultured nucelas callus of citrus cultivars. Zeitschrift fuer Pflanzenphysiologie, Stuttgart, 105: 359-68, 1982.

KOCHBA, J.; BEN-HAYYIN, G.; SPIEGEL-ROY, P.; SAAD, S.; NEUMANN, $H$. Selection of stable salt-tolerant callus cell lines and embryos in Citrus sinensis and $C$. aurantium. Zeitschrift fuer Pflanzenphysiologie, Stuttgart, 106: $111-8,1982$. 
KOCHBA, J.; BUTTON, J.: SPIEGEL-ROY, P.; BORNMAN, C.H.: KOCHBA, M. Stimulation of rooting of Citrus sulphate by gibberelic and adenine sulphate. Annals of BoBotany, London, 38: 755-802, 1974.

LARANJA. Agroanalysis, Rio de Janeiro, $12(2): 28-32$, fev. 1988.

LARKIN, P.J. Purification and viability determinations of plant protoplasts. Planta, Heidelberg, 128: 213-6, 1976.

MAHESWARI, P. \& RANGASWAMY, N.S. Polyembriony and in vitro culture of Citrus and Mangifera. Indian Journal Horticulture, Bangalore, 15: 275-86, 1958.

MATSUMOTO, $K$. \& YAMAGUSHI, $H$. Induction of adventicious buds and globular of seedings of trifoliate orange (Poncirus trifoliata). Japanese Journal Breeding, Tokyo, 33 $(2): 123-9,1983$.

MATSUMOTO, K. \& YAMAGUSHI, H. Increased variation of NaCltolerance in adventicious embryoids of trifoliate orange using an in vitro technique. Revista Brasileira de Genética, Ribeirão Preto, $2(1): 73-82,1984$.

MEINS, F. Mechanisms underlying the persistence of tumor anatomy in crown-gall disease. In: STREET, H.E., ed. Tissue culture and plant science. New York, Academic Press, 1974. P.233-64.

MITRA, G.C. \& CHATURVEDI, H.C. Embryoids and complete plants from unpollinated ovaries and from ovules of in vivo grown emasculated flower buds of Citrus spp. Bulletin of the Torrey Botanical Club, Bronx, 99: 184-9, 1972 . 
MOORE, G.A. Factors affecting in vitro embryogenesis from undeveloped ovules of mature Citrus fruit. Journal of American Soclety for Horticultural Science, Alexandria, 110: $66-70,1985$.

MOORE, G.A. In vitro propagation of citrus rootstocks. HortScience, Alexandria, $21(2)$ : 300-1, 1986.

MURASHIGE, T. \& SKOOG, F. A revised medium for rapid growth and bioassays with tobacco tissue cultures. Physiologia Plantarum, Copenhagen, 15: 473-97, 1962.

MURASHIGE, T. \& TUCKER, D.P.H. Growth factor requirements of citrus tissue culture. In: INTERNATIONAL CITRUS SYMPOSIUM, 1., Riverside, 1968. Proceedings, Riverside, Univiersity of California, 1969. v.3, p.1155-66.

NAGATA, T. \& TAKEBE, I. Plant of isolated tobacco mesophyl protoplasts on agar medium. Planta, Heidelberg, 99: $12-20,1971$.

NAVARRO, L. \& JUAREZ, J. Tissue culture techniques used in Spain to recover virus-free citrus plants. Acta Horticuturae, Wageningen, 78: 425-35, 1977.

NEGRUTIU, T.; JACOBS, M.; CABOCHE, M. Advances in somatic cell genetics of higher plants - the protoplast Nygeren, A. Encycl. P1. Physial., 15(1), 1984.

OHGAWARA, T.; KOBAYASHI, 5.; ISHILL, S.; YOSHINAGA, K.: OIYAMA, I. Somatic hybridization in citrus: navel orange (C. sinensis Osb.) and grapefruit ( $C$. paradisi Macf.). Theoretical Applied Genetics, Berlin, 78: 60912,1989 . 
OHGAWARA, T.; KOBAYASHI, S.; OHGAWARA, E.; UCHIMIYA, H.; ISHILL, 5. Somatic plants obtained by protoplasts fusion between citrus sinensis and poncirus trifoliata. Theoretical and Applied Genetics, Berlin, 71: 1-4, 1985.

OHTA, $Y$. FURUSATO, $K$. Embryoculture in citrus. Reports of the Kihara Institute for Biological Research, Kuala, $8: 49-54,1957$.

PASQUAL, M. Regeneraça de plantas in vitro e radiossensitividade de tecidos nucelares de citros. Piracicaba, 1985. 106p. (Doutorado - Escola Superior de Agricultura "Luiz de Queiroz"/USP).

PASQUAL, M.; ANDO, A.; CROCOMO, O.J. Influencia de reguladores de crescimento sobre a embriogenese in vitro de nucelos de Citrus sinensis cv. Valencia. Pesquisa Agropecuária Brasileira, Brasflia, 23(3): 255-9, 1988.

PATEL, K.R. \& BERLYN, G.P. Genetic instability of multiple bride of Pinus coulteri regenerated from tissue culture. Canadian Journal of Forestry Research, Ottawa, 19: 93-101, 1982.

PATEL, K.R. \& THORPE, T.A. Histochemical examination of shoot initiation in cultured cotyledon explant of radiata pine. Botanical Gazzete, Chicago, 145: 312-22, 1984 .

RANGAN, T.S.; MURASHIGE, T.; BITTERS, W.P. In vitro initiation of nucellar embryos in monoembryonic citrus. HortScience, Alexandria, 3: $226-7,1968$. 
RANGAN, T.S. MURASHIGE, T.: BITTERS, W.P. In vitro studies of zygotic and nucellar embryogenesis in citrus. In: INTERNATIONAL CITRUS SYMPOSIUM, 1, 1969. Proceedings. P. 225-9.

RANGASWAMY, N.S. Culture of nucellar of citrus in vitro. Experientia, Base1, 14: 111-2, 1958.

RANGASWAMY, N.S. Morphogenetic response of Citrus ovules to growth adjuvants in culture. Nature, London, 183(4663): $735-6,1959$.

RANGASWAMY, N.S. Experimental studies on female reproductive structures of citrus microcarpa Bunge. Phytomorphology, New Delini, 11: 108-27, 1961.

RUMARY, C.; PATEL, K.R.; THORPE, T.A. Plantlet formation in black and white Sprince. II. Histological analysis of adventitious shoot formation "in vitro". Canadian Journal of Botany, Ottawa, 69: 997-1002, 1986.

RUSSO, F.; DONINI, B.; STARRANTINO, A. Mutagenesis applied for citrus improvement. Proceedings of International Society for Citriculture, $1: 68-70,1981$.

SAAD, S. Factor affecting the growth of lemon (C. Iimon) callus in vitro culture. M.S. Hebrew University, Jerusalem, 1975.

SABHARWAL, P.S. In vitro culture of ovules, nucelli and embryos of Citrus arantifolia Swingle. In: MAHESWARI, P. \& RANGASWAMY, N.5., ed. Plant tissue and organ culture. Univ. of Delhi, 1963. P.265-74. 
SALIBE, A. Propagacão das plantas citricas. Curso de especializaçao em citricultura a nivel de pós-graduaça, Recife, s.ed., 1969. P.52-60.

SASS, J.E. Botanical microtechnique. Iowa, The Iowa State College Press, 1951. 228p.

SCHULTHEIS, R.J.; CHEW, R.P.; CANTLIFFE, D.J. EmbriBES somáticos e sementes sintéticas. In: TORRES, A.C. e CALDAS, L.S., eds. Técnicas e aplicaçZes da cultura de tecidos de plantas. Brasilia, ABCTP, EMBRAPA/CNPH, 1990. p.213-27.

SKIRVIN, R. Natural and induced variation in tissue culture. Euphytica, Wageningen, $27(1): 241-66,1978$.

SKOOG, F. \& MILLER, C.O. Chemical regulation of growth and organ formation in plant tissues cultivated in vitro. In: Biological Action of Growth Substances. 11 th. Symp. Soc. Exp. Biol., 11: 118-31, 1957.

SOOST, R.K. Self-incompatibility in Citrus grandis (Linn.) Osbeck. Proceeding of American Society for Horticulture Science, Alexandria, 84: 137-40, 1964.

SOOST, R.K. \& CAMERON, J.W. CitruS. In: JANICK, J. \& MOORE, J.N., ed. Advances in fruit breeding. West Lafayette, Purdue University Press, 1975. p.507-40.

SPIEGEL-ROY, P. \& BEN-HAYYIN, G. Selection and breeding for salinity tolerance in vitro. Plant and Soil, Dordrecht, 89: $243-52,1985$. 
SPIEGEL-ROY, P. KOCHBA, J. Stimulation of differentiation in orange (Citrus sinensis) ovular callus in relation to irradiation of the media. Radiation Botany, Oxford, 13: $97-103,1973$.

SPIEGEL-ROY, P. \& KOCHBA, J. Production of solid mutants in citrus, using new approaches and techniques. In: INTERNATIONAL ATOMIC ENERGY AGENCY. Improvements of vegetatively propagated plants through induced mutations. Vienna, 1975. p.113-27.

SPIEGEL-ROY, P. \& VARDI, A. Citrus. In: EVANS, D.A.; SHARP, W.R., AMMIRATO, P.V.; YAMADA, Y., ed. Handbook of plant cell culture, vol. 4. New York, Macmillan, 1984. p. 355-71.

SPIEGEL-ROY, P.; KOCHBA, J.; SAAD, S. Selection for tolerance to 2,4-dichlorophenocyacetic acid in ovular callus of orange (Citrus sinensis). Zeits chrift fuer Pflanzenphysiologie, stuttgart, $109: 41-8,1983$.

SPIEGEL-ROY, P.; VARDI, A.; ELHANATI, A. Seedless induced mutant in lemon (Citrus limon). Mutation Breeding Newsletters, Vienna, $26: 1-2,1985$.

STARRANTINO, A. \& RUSSO, $F$. Coltura in vitro di nucelle isolate da frutticini de limone irraggiati con ${ }^{\infty} \mathrm{Co}$. Tentative per ottenere semenzali nucellari resistenti al 'mal secco'. Annali Istituto Sperimentale per 1 Agrumicoltura, Acireale, 9/10:209-21, 1976/1977. 
STARRANTINO, A. RUSSO, F. Seedlings from undeveloped ovules of ripe fruits of polyembryonic citrus cultivars. HortSciencce, Alexandria, $15(3): 296-7,1980$.

TEOFILO SOBRINHO, J. Variedades copas e porta-enxertos para os citros. In: MENTEN, J.O.M.; DOURADO NETO, D.: TORRADO, P.V., ed. Curso intensivo de citricultura. Piracicaba, A.E.C. CERES; ESALQ, 1991. p.25-36.

THORPE, T.A. \& MEIER, D.D. Starch metabolium, respiration, and shoot formation in tobacco callus cultures. Physiologia Plantarum, Copenhagen, 27: 365-9, 1972.

THORPE, T.A. \& MURASHIGE, T. Starch accumulation in shoot forming tobacco callus cultures. Science, Washington, 160: $421-2,1968$.

TISSERAT, B. Embryogenesis, organogenesis and planta regeneration. In: DIXON, R.A., ed. Plant cell culture, oxford, IRL Press, 1985. P.79-104.

TISSERAT, B. MURASHIGE, T. Effect of ethephon, ethylene and 2,4-dichlorophenoxyacetic acid on sexual embryogenesis in vitro. Plant Physiology, Rockville, 60: 4379, 1977 .

TULMANN NETO; A.; MENTEN, J.O.M.; ANDO, A.; POMPEU JUNIOR, J.; CERAVOLO, L.; NAKEMATA, T.; ROSSI, A.C. Mutation breeding aiming at obtaining resistance to citrus canker (Xanthomonas campestris pv. citru) and other characteristics in sweet orange (Citrus sinensis Osb.). In: INTERNATIONAL SYMPOSIUM ON THE CONTRIBUTION OF PLANT MUTATION TO CROP IMPROVEMENT, VIENTA, 1990. Extended Symopses.Vienna, IAEA; Rome, FAO, 1990. p.182-3. 
TUSA, N.; GROSSER, J.W.; GMITTER Jr., F.B. Plant regeneration of "valencia" Sweet Orange, "Femminello" Lemon, and the interespecific somatic hybrid following protoplast fusion. Journal of the American Society for Horticultural Science, Alexandria, 115(6): 1043-6, 1990.

VARDI, A. Isolation of protoplasts in Citrus. Proceedings of the International Society Citriculture, 2 : 575-8, 1977 .

VARDI, A. \& GALUN, E. Recent advances in protoplast culture of horticultural crops: Citrus. Scientia Horticulturae, Amsterdam, 37: 217-30, 1988 .

VARDI, A.; BLEICHMAN, S.; AVIV, D. Genetic transformation of citrus protoplasts and regeneration of transgenic plants. Plant Science, Limerick, 69: 199-206, 1990.

VARDI, A. RAVEH, D. Cross-feeder experiments between tobacco and orange protoplasts. Zeitschrift fuer Pflanzenphysiologie, Stuttgart, $78: 350-9,1976$.

VARDI, A.; BREIMAN, A.; GALUN, E. Citrus cybrids: production of donor-recipient protoplast-fusion and verification by mitochondrial-DNA restriction profiles. Theoretical Applied Genetics, Berlin, 75: 51-8, 1987.

VARDI; A.; EPSTEIN, E.; BREIMAN, A. Is the Phytophthora citrophthora culture filtrate a reliable tool for in vitro selection of resistant Citrus variants? Theoretical and Applied Genetics, Berlin, 72: 569-74, 1986. 
VARDI, A.; SPIEGEL-ROY, P.; GALUN, R. Citrus cell culture: isolation of protoplasts, plating densities, effect of mutagens and regeneration of embryos. Plant science Letters, Limerick, 4: 231-6, 1975.

VARDI, A.; SPIEGEL-ROY, P.; GALUN, E. Plant regeneration from Citrus protoplasts. Variability in methodological requirements among cultivars and species. Theoretical and Applied Genetics, Berlin, 62: 171-6, 1982.

VARDI, A.; PARZER-GONEN, A.; FRYDMNAN-SHANI; CLEICHMAN, S., GALUN, E. Protoplast fusion mediated transfer of organelles from Microcitrus into Citrus and regeneration of novel alloplasmic tress. Theoretical and Applied Genetics, Berlin, 78: 741-7, 1989.

VASIL, I.K. Regeneration of plants from single cells of cereals and grasses. In: LURQUIN, P.F.; KLEINHOFS, A., eds. Genetic engineering in eukaryote, New York, Plenum, 1983. p.233-52.

VENVERLOO, C.J.; KOSTER, J.; LIBBENGA, K.R. The formation of adventicious organs. IV. The ontogeny of shoots and leaves from epidermis cells of Nautilocalyx lynchil. Zeitschrift fuer Pflanzenphysiologie, Stuttgart, 109 : $55-67,1983$.

WATANABE, H. Fi hybrids obtained through the regulation of polyembryony by continuous gamma irradiation in citrus unsher cultivars. Journal of the American Society for Horticultural Science, Alexandria, 110: 742-4, 1985. 
WIDHOLM, J.M. The use of fluorescein diacetate and phenosafranine for determining viabilkity of culture plant cel1s. Stain Technology, Baltimore, 47: 189-94, 1972.

WILLIAMS, E.G. MAHESWARAN, G.M. Somatic embryogenesis: factors influencing coordinated behaviour of cells as an embryogenit group. Annals of Botany, London, 57: 443-62, 1986.

YEUNG, E.C.; AITKEN, J.; BIONDI, S.; THORPE, T.A. ShoOt histogenesis in cotyledon explants of radiata pine. Botanical Gazette, Chicago, 142: 494-501, 1981.

ZHANAO, D.; WENCAI, Z.; SHUYAN, W. In vitro mutation breeding for salinity tolerance in Citrus Mutation. Breeding Newsletter, Vienna, 33: 12-14, 1989.

ZUBRZYCKI, H.M. \& ZUBRZYCKI, D.A. Induction of mutations in Citrus to produce resistance to the Tristeza virus. In: INTERNATIONAL ATOMIC ENERGY AGENCY. Induced mutations in vegetatively propagated plants II, Vienna, 1982, vol. 2, p.111.

ZUBRZYCKI, H.M. \& ZUBRZYCKI, D.A. Induction of mutations in Citrus for the development of resistance to xanthomonas citri (Hasse) Dowson. In: INTERNATIONAL ATOMIC ENERGY AGENCY. Induced mutations in regetatively propagated plants II, Vienna, 1982, vol. $2, p .91-110$. 